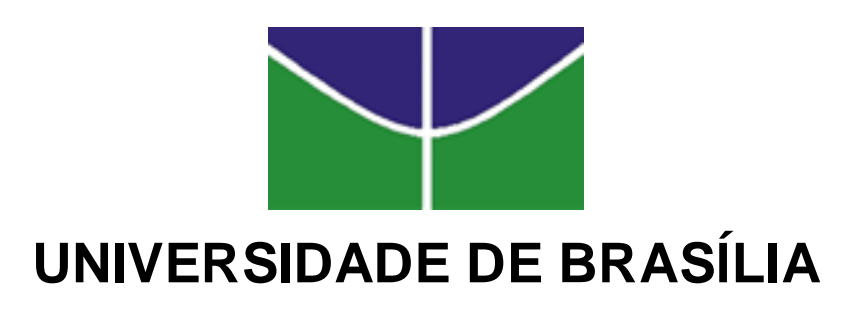

FACULDADE DE AGRONOMIA E MEDICINA VETERINÁRIA PROGRAMA DE PESQUISA E PÓS-GRADUAÇÃO EM AGRONEGÓCIO

LUCAS AUGUSTO ESMERALDO DE OLIVEIRA

ESTUDO DO MERCADO DE CONSUMO E CANAIS DE COMERCIALIZAÇÃO DE PRODUTOS ORGÂNICOS NO DISTRITO FEDERAL

PUBLICAÇÃO: 140/2017

Brasília

Março/2017 
Lucas Augusto Esmeraldo de Oliveira

\section{ESTUDO DO MERCADO DE CONSUMO E CANAIS DE COMERCIALIZAÇÃO DE PRODUTOS ORGÂNICOS NO DISTRITO FEDERAL}

Dissertação apresentada ao curso de Mestrado do Programa de Pós-Graduação em Agronegócios, da Faculdade de Agronomia e Veterinária da Universidade de Brasília (UnB), como requisito parcial para obtenção do grau de Mestre em Agronegócios.

Orientadora: Professora PhD. Ana Maria Resende Junqueira

Brasília, DF

Março/2017 


\section{FICHA CATALOGRÁFICA}

Oliveira, L..A.E. Estudo do mercado de consumo e canais de comercialização de produtos orgânicos no Distrito Federal. 2017, 141 f. Dissertação. (Mestrado em Agronegócio) - Faculdade de Agronomia e Medicina Veterinária, Universidade de Brasília, Brasília, 2017.

Documento formal, autorizando reprodução desta dissertação de mestrado para empréstimo ou comercialização, exclusivamente para fins acadêmicos, foi passado pelo autor à Universidade de Brasília e achase arquivado na Secretaria do Programa. O autor reserva para si os outros direitos autorais, de publicação. Nenhuma parte desta dissertação de mestrado pode ser reproduzida sem a autorização por escrito do autor. Citações são estimuladas, desde que citada a fonte.

\section{FICHA CATALOGRÁFICA}

\section{OLIVEIRA, LUCAS AUGUSTO ESMERALDO}

OL933e Estudo do mercado de consumo e canais de comercialização de produtos orgânicos no Distrito Federal / LUCAS AUGUSTO ESMERALDO OLIVEIRA;

orientador ANA MARIA RESENDE JUNQUEIRA. -- Brasília, 2017. $141 \mathrm{p}$.

Dissertação (Mestrado - Mestrado em Agronegócios) - Universidade de Brasília, 2017. 


\section{LUCAS AUGUSTO ESMERALDO DE OLIVEIRA}

\section{ESTUDO DO MERCADO DE CONSUMO E CANAIS DE COMERCIALIZAÇÃO DE PRODUTOS ORGÂNICOS NO DISTRITO FEDERAL}

Dissertação apresentada ao curso de Mestrado do Programa de Pós-graduação em Agronegócios da Faculdade de Agronomia e Medicina Veterinária da Universidade de Brasília (UnB), como requisito parcial para a obtenção do grau de Mestre em Agronegócios.

Aprovada pela seguinte Banca Examinadora:

Ana Maria Resende Kungueina

Prof. PhD. Ana Maria Resende Junqueira - Universidade de Brasília

(Orientadora)

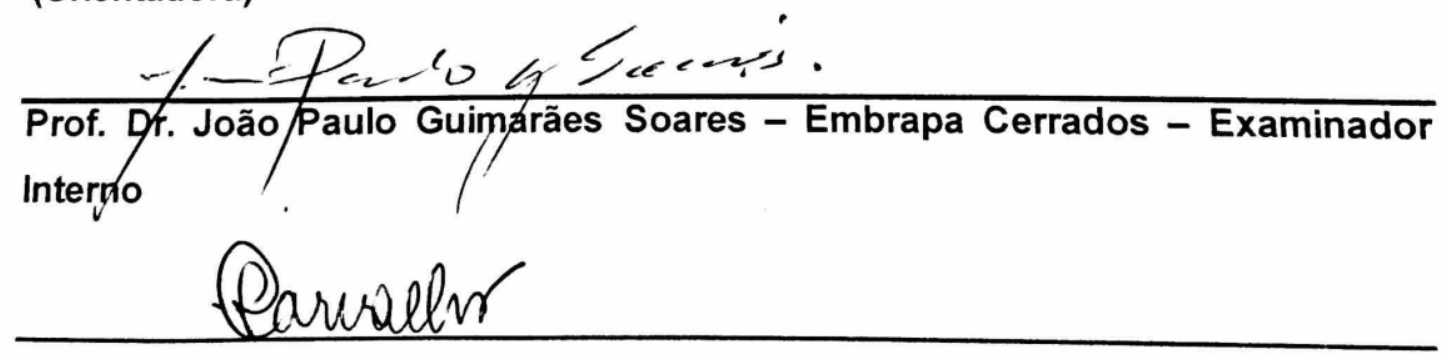

Prof. Dra. Flaviane de Carvalho Canavesi - Universidade de Brasilia -

Examinador Externo

Brasília, 07 de março de 2017. 
Dedico este trabalho a minha mãe que sempre me incentivou na construção do conhecimento. 
Agradeço a Deus.

Agradeço a minha mãe que sempre me deu força para alcançar meus objetivos. E me apoiou na busca pela realização desse sonho.

Aos meus avós pelo incentivo ao estudo e a construção do conhecimento, onde sempre me acolheram e me fizeram consciente de um crescimento contínuo e gradual. 
"O sucesso é ir de fracasso em fracasso sem perder entusiasmo" Winston Churchill 


\section{RESUMO}

O objetivo do trabalho é a análise do perfil do consumidor e dos canais de comercialização de produtos orgânicos no Distrito Federal. A fundamentação teórica contempla a descrição, caracterização e legislação, assim como as características do mercado e agregação de valor dos produtos orgânicos. A pesquisa possui natureza aplicada e descritiva, classificada como quantitativa, com coleta de dados estruturados a partir da aplicação de dois questionários. $\mathrm{O}$ primeiro foi aplicado com intuito de determinar o perfil dos consumidores de produtos orgânicos no Distrito Federal composto de com informações sociodemográficas e de comportamento do consumidor. O segundo questionário visa analisar a competitividade dos atuais canais de comercialização de produtos orgânicos no Distrito Federal. Composto por informações sociodemográficas e de competitividade. Em média ponderada foi possível observar que os fatores levados em consideração, em ordem de prioridade, no momento da compra pelos consumidores são: Saúde $(4,27)$, Riqueza Nutricional $(4,06)$, Sabor $(4,01)$, Aparência/Aspecto Visual (3,73), Origem do Produto (confiança) (3,57), Selo de Responsabilidade ambiental $(3,53)$, Preço $(3,48)$, Disponibilidade do Produto $(3,42)$, Selo de Responsabilidade social $(3,39)$, Influência de Família/Amigos $(2,34)$ e Influência da Mídia $(1,93)$. Os principais canais de comercialização de produtos orgânicos, em percentual, identificados no Distrito Federal foram as Feiras $(53,9 \%)$, hipermercados e supermercados $(35,2 \%)$, empórios e lojas especializadas $(4,7 \%)$, as Comunidades que Suportam a Agricultura $(4,1 \%)$ e a internet com apenas $(2,6 \%)$ dos locais de compra dos consumidores de produtos orgânicos. Diante deste cenário foi elaborado um plano de negócios de uma cooperativa de consumidores de produtos orgânicos que pela percepção dos produtores, a EMATER-DF e o SEBRAE-DF se torna uma alternativa positiva e viável para o Distrito Federal.

Palavras-chave: Comportamento do Consumidor. Produtos Orgânicos. Cooperativa de Consumidores. 


\begin{abstract}
The objective of this work is the analysis of the profile of the consumer and the marketing channels of organic products in the Federal District. The theoretical basis includes the description, characterization and legislation, as well as the characteristics of the market and aggregation of value of organic products. The research has an applied and descriptive nature, classified as quantitative, with data collection structured from the application of two questionnaires. The first one was applied in order to determine the profile of consumers of organic products in the Federal District composed of sociodemographic information and consumer behavior. The second questionnaire aims to analyze the competitiveness of the current organic product marketing channels in the Federal District. Composed of sociodemographic and competitiveness information. In a weighted average, it was possible to observe that the factors considered in order of priority at the moment of purchase by consumers are: Health (4.27), Nutrition Wealth (4.06), Flavor (4.01), Appearance / Aspect Visual (3.73), Product Origin (confidence) (3.57), Environmental Responsibility Seal (3.53), Price (3.48), Product Availability (3.42), Social Responsibility Seal (3.39), Influence of Family / Friends (2.34) and Influence of Media (1.93). The main commercialization channels of organic products, identified in the Federal District, were the Fairs (53.9\%), hypermarkets and supermarkets $(35.2 \%)$, emporiums and specialized stores (4.7\%), Communities They support Agriculture (4.1\%) and the Internet with only (2.6\%) of the buying places of consumers of organic products. In view of this scenario, a business plan was drawn up for a consumer cooperative of organic products that through the producers' perception, EMATER-DF and SEBRAE-DF became a positive and viable alternative for the Federal District.
\end{abstract}

Keywords: Consumer Behavior. Organic products. Consumer Cooperative. 


\section{LISTA DE ILUSTRAÇÕES}

Figura 1 - Logotipo Cooperativa de Consumidores. ............................................................... 74

Figura 2 - Organograma Cooperativa de Consumidores. ...................................................... 77

Figura 3 - Agenda de Trabalho Voluntário Cooperativa de Consumidores. ..................... 79

Figura 4 - Escala de trabalho dos cooperados. ............................................................................................ 79

Figura 5 - Folha de ponto dos cooperado. ....................................................................8

Figura 6 - Planta baixa e 3D Cooperativa de Consumidores 30 $\mathrm{m}^{2}$. ......................................82

Figura 7 - Planta baixa e 3D Cooperativa de Consumidores $150 \mathrm{~m}^{2}$........................................ 83

Figura 8 - Planta baixa e 3D Cooperativa de Consumidores $300 \mathrm{~m}^{2}$. ....................................... 84 


\section{LISTA DE TABELAS}

Tabela 1 - Principais países produtores da agricultura orgânica..........................................20

Tabela 2 - Nível de satisfação em relação ao ambiente de compra.......................................38

Tabela 3 - Locais de compra de produtos orgânicos no DF....................................................... 40

Tabela 4 - Locais de compra de produtos orgânicos do Distrito Federal............................ 42

Tabela 5 - Reclamações dos consumidores de orgânico................................................................ 43

Tabela 6 - Vantagens da cooperativa de consumidores de orgânico....................................... 44

Tabela 7 - Motivos de consumo de orgânicos. ...................................................................................... 49

Tabela 8 - Fatores importantes ao realizar a compra de orgânicos.............................................53

Tabela 9 - Análise do mercado de produtos orgânicos do Distrito Federal.........................59

Tabela 10 - Entrevista EcoTorres......................................................................................................... 76

Tabela 11 - Custos Operacionais mercearia 30m² $\ldots$

Tabela 12 - Móveis e utensílios escritório da cooperativa.......................................................91

Tabela 13 - Mercearia 150m² área de vendas. .........................................................................................992

Tabela 14 - Móveis e utensílios - Área de venda $150 \mathrm{~m}^{2}$................................................................ 93

Tabela15 - Custos escritório 30m² ....................................................................................................94

Tabela 16 - Supermercado 300m² - área de vendas. ..........................................................................94

Tabela 17 - Móveis e utensílios - Escritório da Cooperativa..........................................................95

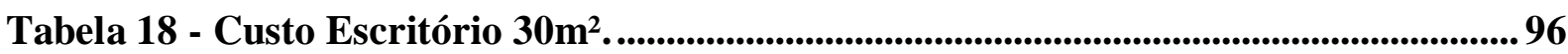

Tabela 19 - Custo fixo mensal mercearia $30 \mathrm{~m}^{2}$. ..........................................................................97

Tabela 20 - Custo fixo mensal mercearia $150 \mathrm{~m}^{2}$....................................................................................98

Tabela 21 - Custo fixo mensal supermercado 300m² ...................................................................... 98

Tabela 22 - Custos salários mercearia 30m²

Tabela 23 - Custos salários loja 150m².............................................................................100

Tabela 24 - Custo mensal salários supermercado 300m² .......................................................100

Tabela 25 - Desconto de mão de obra voluntária $30 \mathrm{~m}^{2}$.............................................................. 101

Tabela 26 - Desconto de mão de obra voluntária $150 \mathrm{~m}^{2}$................................................... 102

Tabela 27 - Desconto de mão de obra voluntária $300 \mathrm{~m}^{2}$......................................................... 102

Tabela 28 - Estimativa de faturamento $30 \mathrm{~m}^{2}$. ................................................................................ 103

Tabela 29 - Estimativa de faturamento $150 \mathrm{~m}^{2}$....................................................................104

Tabela 30 - Estimativa de faturamento $300 \mathrm{~m}^{2}$. ................................................................................... 104

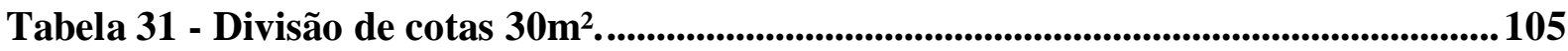

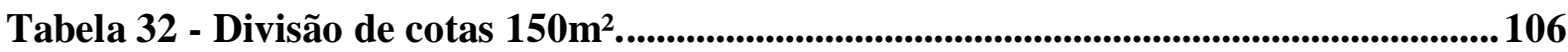

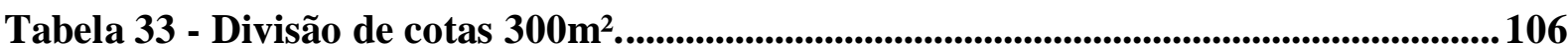




\section{LISTA DE ABREVIATURAS E SIGLAS}

AAO - Associação de Agricultura Orgânica.

ABIO - Associação de Agricultores Biológicos.

AGE - Associação de Agricultura Ecológica.

ANC - Associação de Agricultura Natural de Campinas e Região.

APAN - Associação dos Produtores de Agricultura Natural.

APEX - Agência Brasileira de Promoção de Exportação e Investimento.

BRASILBIO - Associação Brasileira de Orgânicos.

CEASA - Centrais de Abastecimento do Distrito Federal.

CMO - Certificadora Mokiti Okada.

CODEPLAN - Companhia de Planejamento do Distrito Federal.

CSA - Comunidade que Sustenta a Agricultura.

ECOCERT - Organismo de Inspeção e Certificação.

EMBRAPA - Empresa Brasileira de Pesquisa Agropecuária.

FIBL - Instituto de Pesquisa da Agricultura Orgânica.

FVO - Farm Verified Organic.

IBD - Associação de Certificação Instituto Biodinâmico.

IFOAM - Federação Internacional dos Movimentos de Agricultura Orgânica.

IMO - Instituto de Mercado Ecológico.

INMETRO - Instituto Nacional de Metrologia Normalização e Qualidade Industrial.

MAPA - Ministério da Agricultura Pecuária e Abastecimento.

OCS - Organismo de Controle Social.

OIA - Organização Internacional Agropecuária.

OPAC - Organismo Participativo de Avaliação da Conformidade.

SEBRAE - Serviço Brasileiro de Apoio às Micro e Pequenas Empresas.

SINDIORGÂNICO - Sindicato dos Produtores Orgânicos do Distrito Federal.

SISORG - Sistema Brasileiro de Avaliação da Conformidade Orgânica.

TECPAR - Instituto de tecnologia do Paraná. 


\section{SUMÁRIO}

1 INTRODUÇÃ

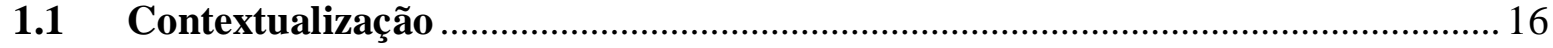

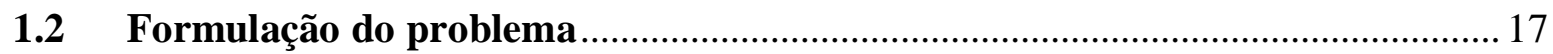

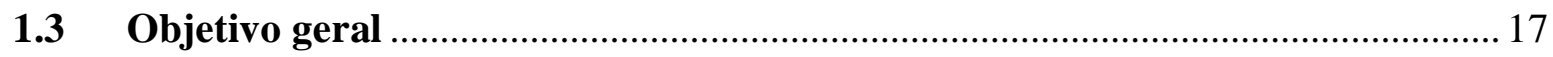

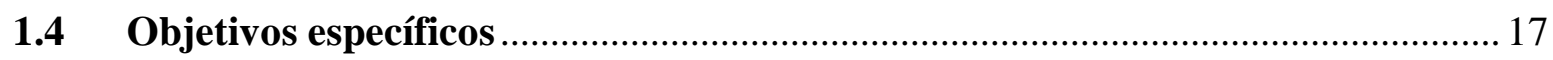

2 REFERENCIAL TEÓRICO .............................................................................................. 18

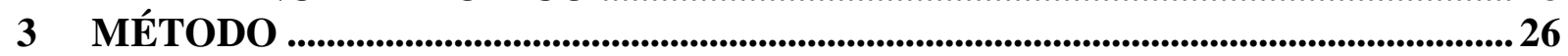

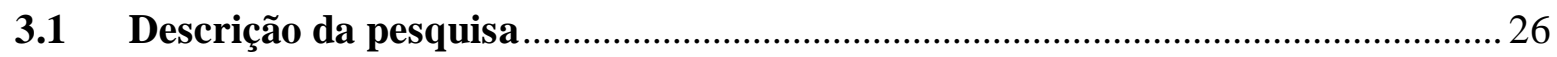

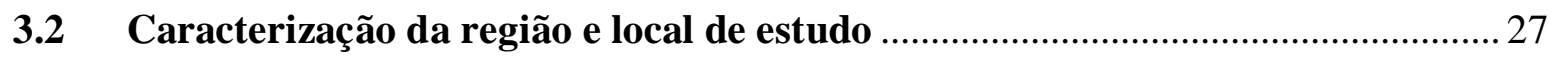

3.3 Caracterização dos consumidores e agentes de comercialização ........................ 27

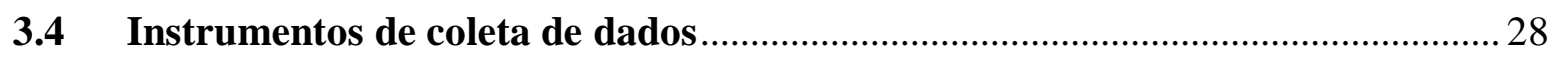

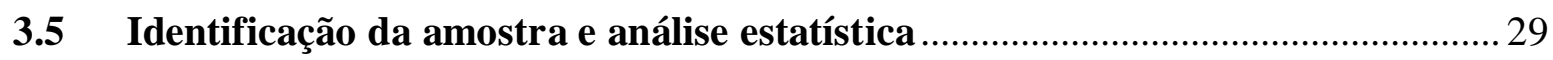

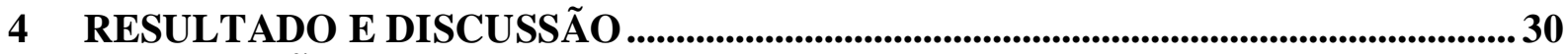

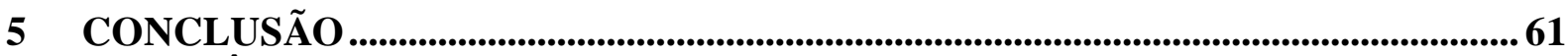

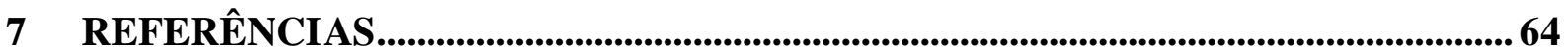

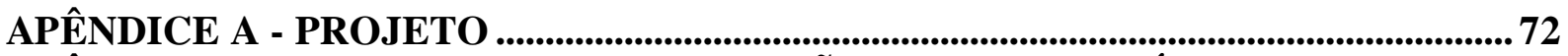

APÊNDICE B - FICHA PARA CONVOCAÇÃ̃O DE ASSEMBLÉIA ................................. 108

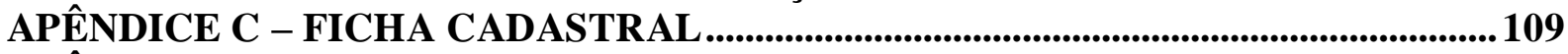

APÊNDICE D - FICHA CADASTRAL PRODUTOR ........................................................ 110

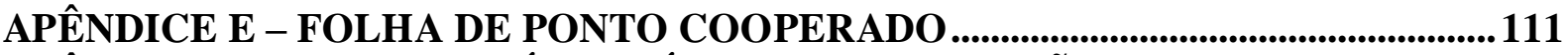

APÊNDICE F - QUESTIONÁRIO NÍVEL DE SATISFAÇÃO DE PRODUTOS

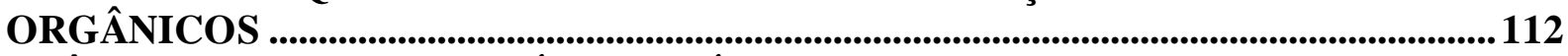

APÊNDICE G - QUESTIONÁRIO ANÁLISE COMPETITIVA DOS CANAIS DE

COMERCILIZAÇÃO DE PRODUTOS ORGÂNICOS APÊNDICE F ............................. 118

APÊNDICE H - ENTREVISTA ECOTORRES.........................................................126 


\section{INTRODUÇÃO}

O produto orgânico brasileiro é percebido como alimento saudável e sem a utilização de agrotóxicos (Instituto de Promoção do Desenvolvimento, 2011). É importante destacar que os produtos orgânicos ganham espaço na preferência do consumidor, os quais, segundo Viglio (1996), são considerados uma forte tendência de consumo, pautados em métodos rigorosos de produção, criando um roteiro sistemático de cultivo, que não prioriza os vultuosos lucros em detrimento da degradação ambiental. Além de uma intensa preocupação socioambiental (ORMOND; PAULA; FILHO; ROCHA, 2002), que promove benefícios desde o sistema de produção sustentável, o respeito ao produtor e ao meio ambiente.

O desenvolvimento da agricultura orgânica teve como fator influenciador as mudanças enfrentadas pelo modelo de produção convencional, e as mudanças relacionadas às preferências de consumo ao longo do tempo. Ehtlers (1996) aponta que a agricultura convencional proporcionou aumentos significativos de ganhos de produtividade, dobrando a produção de alimentos entre 1950 e 1984 . No entanto, a partir de 1985 passou-se a observar uma diminuição da produtividade (RESENDE; SOUZA; 2006).

Em meados da década de 1990, faz-se uma análise crítica em torno da natureza e do desenvolvimento dos sistemas produtivos contemporâneos de fornecimento de alimentos, refletindo o aumento das preocupações da sociedade sobre as práticas agrícolas e agroindustriais nas dimensões de segurança, saúde ambiental e alimentar (ILBERY; MAYE; 2005). Com o objetivo de obter maiores ganhos financeiros, a prática da agricultura convencional não prioriza a dinâmica ecológica do agroecossistema, que desencadeia uma situação de insustentabilidade, posto que deteriora as condições que possibilitam a produção de alimentos para a crescente população mundial (RESENDE; SOUZA; 2006).

Vidal e Resende (2008) defendem que o uso crescente dos adubos químicos e agrotóxicos possibilitou a simplificação dos sistemas agrícolas, de forma que apenas uma cultura pudesse ser cultivada em determinada região para atender as necessidades locais ou as exigências do mercado. Esse modelo permitiu o aparecimento de pragas, doenças, plantas invasoras e uma série de outros problemas peculiares para essas culturas. A manutenção da fertilidade do solo e a sanidade dos cultivos dependem de rotações de culturas, da reciclagem de biomassa e, principalmente, da diversidade biológica. Essa diversidade é o principal pilar da agricultura orgânica a contribuir para a manutenção do equilíbrio do sistema e, 
consequentemente, do solo e da cultura. Portanto, o equilíbrio biológico e ambiental, bem como a fertilidade do solo, não pode ser mantido como monoculturas.

Assim, segundo Renting, Marsden e Banks (2003), a percepção dos consumidores passou por importantes mudanças em relação aos alimentos e a produção agrícola. Tais mudanças são consequência do aumento da preocupação pública sobre questões relacionadas a ecologia, saúde e bem-estar dos animais e, principalmente, da crescente desconfiança em relação a qualidade dos alimentos advindos da agricultura convencional (RENTING; MARSDEN; BANKS, 2003). A forte elevação da demanda por produtos orgânicos está ligada aos métodos de trabalho referentes à terra, vegetais e animais em conformidade com a preservação ambiental (FONSECA, 2005). É possível observar uma evolução significativa perante outros países na produção de determinados alimentos orgânicos.

A produção de produtos orgânicos já está presente em 172 países, e movimentou no ano de 2014 um total de 80 milhões de dólares em todo o mundo, o mercado americano apresentou o maior crescimento (FiBL; Organic Monitor; 2016). Em 2012 a América Latina representava $15 \%$ de toda produção mundial de itens orgânicos, dentro dessa perspectiva o Brasil é o terceiro maior produtor da região, responsável por 0,7 milhões de hectares, atrás apenas da Argentina com 3 milhões de hectares, e Uruguai com 1,3 milhões de hectares (The World of Organic Agriculture, 2016). Austrália e Nova Zelândia apresentam sinais de crescimento, e parte de sua produção $(40 \%)$ é destinada à exportação. A Austrália exporta para países europeus como Alemanha, Holanda e Reino Unido. Nova Zelândia divide sua produção com o mercado americano, asiático e parte da Europa. Os países asiáticos formam o terceiro maior grupo de consumidores de produtos orgânicos no mundo, boa parte é representada pelas importações do Japão.

As mudanças apresentadas ao longo do tempo relacionadas a produção, preservação ambiental, consciência do consumidor em relação as práticas de produção, e a utilização dos recursos naturais em todo o mundo influenciaram as formas de comercialização de produtos agrícolas e sua interação com o meio. As longas cadeias de comercialização que envolvem grandes intermediários e vários elos até chegar às mãos do consumidor deram lugar a pequenas cadeias de comercialização, com um forte envolvimento entre os consumidores e os produtores rurais, em novos formatos de venda.

As formas tradicionais de comercialização com a presença de grandes varejistas como atacados, hipermercados, supermercados, que priorizam a venda em grande escala, sem uma relação de proximidade entre seus fornecedores e consumidores passaram a não ser o foco de compra dos consumidores da agricultura orgânica. Quando os modelos tradicionais de venda 
de produtos agrícolas são comparados as formas de comercialização de produtos orgânicos é possível observar novas tendências de comercialização como a possível profissionalização das feiras do produtor, o surgimento de cooperativas de produtores e consumidores, a formação de grupos como as Comunidades que Sustentam a Agricultura (CSA). Essas novas formas de comercialização têm como objetivo aumentar o nível de satisfação do consumidor de orgânicos, democratizar seu acesso por meio da minimização de intermediários, promover a saúde e a preservação ambiental.

\subsection{Contextualização}

Segundo Ilbery e Maye (2015), a inovação tecnológica, a evolução e o uso de maquinário moderno, dentro de um sistema de produção agrícola com características industriais, produções em larga escala e monocultura, dentro de um contexto de concentração de poder de grandes produtores e varejistas trouxe como principal consequência um afastamento entre a agricultura e o alimento, os agricultores e os consumidores. Considera-se que a produção orgânica oferece potencial para desenvolver cadeias curtas de abastecimento, que podem potencialmente, aproximar o produtor e o consumidor oferecendo ganhos maiores aos produtores primários. (MARSDEN; BANKS; BRISTOW, 2000).

Diante do crescimento da agricultura orgânica é possível perceber a reorganização do mercado para atender uma nova demanda de consumidores. As atuais formas de comercialização são divididas em dois principais tipos: os canais indiretos e diretos. Os canais indiretos exigem a presença de um intermediário varejista, como hipermercadistas, supermercadistas, lojas especializadas e restaurantes. Já os canais de comercialização diretos se estipulam uma relação entre o produtor rural e o consumidor sem a presença de nenhum intermediário, ou atravessador, como por exemplo: feiras, cooperativas, associações e comunidades que sustentam a agricultura.

A forma indireta está presente em todo mundo e possui maior representatividade diante dos consumidores, sendo preferência do mercado consumidor em alguns países. A presença do intermediário segundo alguns autores dificulta a vida do produtor rural, e minimiza os ganhos financeiros do produtor (BRASIL, 2007 apud Darolt, 2002).

Os intermediários detêm a maior concentração de vendas de alimentos e bebidas no Brasil, representando quase $80 \%$ do mercado nacional, e quando comparados a outros países as redes de supermercados representam $77 \%$ do canal de distribuição e comercialização de produtos orgânicos no mundo (ABRAS, 2011). É comum perceber modelos de autosserviço especializados em produtos orgânicos, como por exemplo, Biogros (França), Bioethic 
(Alemanha), Planet Organic (Reino Unido), Whole Foods (Estados Unidos), formando grandes redes varejistas para intermediar a relação entre o consumidor e o produtor.

As grandes redes varejistas prevendo a grande aceitação do mercado consumidor optaram por criar estratégias para explorar esse novo nicho de mercado. Ofertar produtos orgânicos por meio da criação de marcas próprias para se aproximar e reforçar a confiança dos consumidores, como é possível observar nas marcas Taeq, do Grupo Pão de Açúcar, Viver da rede Carrefour e a Sentir Bem do grupo WalMart, onde todas elas em sua linha de produtos ofertam também produtos orgânicos (IPD; 2011).

$\mathrm{Na}$ linha contrária modelos de vendas diretas estão presentes no mundo com modelos como Farmer Street Market, mercado de produtores, e CSA (Comunidades que Suportam a Agricultura), ou mesmo feiras Agroecológicas em países da América Latina e Caribe (BRASIL, 2007). Um grande impeditivo que torna esse tipo de comercialização menos presente é a falta de profissionalização dos produtores rurais, a dificuldade de organização, planejamento, noções de mercado, formação de preço, a carência de informações que garantem o sucesso das grandes redes de varejo.

\subsection{Formulação do problema}

Diante do crescente aumento do número de consumidores e das atuais formas de comercialização de produtos orgânicos e agroecológicos no Distrito Federal questiona-se: qual o perfil do consumidor e as características dos canais de comercialização de produtos orgânicos no Distrito Federal? A presente pesquisa pretende responder essa pergunta, por meio do alcance dos objetivos a serem descritos a seguir.

\subsection{Objetivo geral}

O trabalho tem como objetivo analisar a viabilidade de implantação de uma cooperativa de consumidores de produtos orgânicos no Distrito Federal.

\subsection{Objetivos específicos}

a. Analisar os fatores que influenciam a decisão de compra dos consumidores de produtos orgânicos no Distrito Federal;

b. Identificar os principais canais de comercialização de produtos orgânicos no Distrito Federal;

c. Avaliar a percepção dos steakholders diante de uma nova proposta de comercialização de produtos orgânicos no Distrito Federal; 


\section{REFERENCIAL TEÓRICO}

O referencial teórico foi dividido em quatro principais temas, sendo eles: agricultura orgânica, legislação, panorama da produção orgânica, mercado de produtos orgânicos e agregação de valor e valor de mercado. Serão apresentados seus conceitos e aplicabilidade de cada um dos tópicos para garantir o entendimento das análises que serão feitas posteriormente.

\subsection{Agricultura Orgânica}

De acordo com o Ministério da Agricultura Pecuária e Abastecimento - MAPA (2016), para ser considerado orgânico é necessário que o processo de produção seja consciente na utilização do solo, da água, do ar e dos demais recursos naturais. Tendo como objetivo a eliminação do uso de fertilizantes sintéticos, agrotóxicos e transgênicos ou quaisquer substâncias que possam acarretar riscos para a saúde humana e o meio ambiente, visando qualidade de vida e proteção do meio ambiente.

A Associação de Agricultura Orgânica - AAO (2016) complementa que esse tipo de produção fornece produtos mais saborosos, saudáveis e mais duráveis. Por intermédio da agricultura orgânica é possível o desenvolvimento econômico, social e ambiental. Costa (2010) ressalta que a agricultura orgânica vai além da preservação do meio do ambiente, proporcionando também independência financeira e cultural para pequenos agricultores e o fortalecimento de uma cadeia comercial justa.

A partir do entendimento do conceito de agricultura orgânica por alguns autores apresenta-se as características legais do sistema de produção, desde seu conceito até as suas limitações de produção e exigências específicas estipuladas em lei.

\subsection{Legislação}

A “Internacional Federation of Organic Agriculture Moviments" - IFOAM é a entidade responsável por coordenar e reunir todos os processos da produção orgânica no mundo, visando reduzir a assimetria de informações existentes, padronizando as normas e credenciando as agências certificadoras, além de abrigar toda a normatização para o comércio internacional de produtos da agricultura orgânica (IFOAM, 2003). A estrutura organizacional brasileira é composta por um componente governamental, que está no Ministério da Agricultura, Pecuária e Abastecimento- MAPA, na Coordenação de Agroecologia-COAGRE (Brasil, 2003). Nessa coordenação estão contidas as comissões de produção orgânica para cada estado brasileiro. São as CPORGs- Comissões de Produção Orgânica dos respectivos estados da federação, as quais desenvolvem, encaminham e discutem todos os assuntos relacionados á produção orgânica nos respectivos estados (FIGUEIREDO, SOARES; 2012). 
Consideram-se dentro do aparato legal os aspectos de conceituação de agricultura orgânica, segundo Lei $\mathrm{n}^{\circ} 10.831$, de dezembro de 2003, como sendo todo aquele em que se adotam técnicas específicas, mediante a otimização do uso dos recursos naturais e socioeconômicos disponíveis e o respeito à integridade cultural das comunidades rurais, tendo por objetivo a sustentabilidade econômica e ecológica, a maximização dos benefícios sociais, a minimização da dependência de energia não-renovável, e a proteção do meio ambiente (RESENDE, SOUZA; 2006).

Portanto, segundo a Lei $\mathrm{n}^{\circ} 10.831$, de 23 de Dezembro de 2003, resume-se o conceito de sistema orgânico de produção aqueles que contemplam características ecológicas, biodinâmicas, natural, regenerativo, biológico, agroecológico, que buscam otimizar recursos naturais e socioeconômicos disponíveis e o respeito à integridade cultural das comunidades rurais, tendo por objetivo a sustentabilidade econômica e ecológica, a maximização dos benefícios sociais, a minimização da dependência de energia não renovável, empregando, sempre que possível, métodos culturais, biológicos e mecânicos, em contraposição ao uso de materiais sintéticos, a eliminação do uso de organismos geneticamente modificados e radiações ionizantes, em qualquer fase do processo de produção, processamento, armazenamento, distribuição e comercialização, e a proteção do meio ambiente" (BRASIL, 2003). Segundo Figueiredo e Soares (2012) a lei foi regulamentada pelo Decreto no 6323 e suas Instruções Normativas-IN, com destaque para a IN 46 (Brasil 2011) que orientam as práticas e processos para a produção animal e vegetal no Brasil. Sendo necessário relacionar os passos sobre conversão e certificação para adequação aos sistemas orgânicos.

A legislação tem principal característica a regulamentação da prática da atividade de produção orgânica, com intuito de garantir a qualidade dos produtos oferecidos aos consumidores, e também legitimar e resguardar as atividades dos produtores. Um dos processos mais comuns de garantia de qualidade por meio de uma regulamentação é o processo de certificação, prática comumente adotada no mercado internacional para garantia de procedência e qualidade de itens comercializados entre países.

É possível observar a crescente demanda de consumidores de produtos orgânicos no mundo, países que se tornaram especialistas na produção, comercialização e consumo. Este trabalho busca de forma resumida apresentar dados deste crescimento em um aspecto mundial, brasileiro e regional quando se fala do Distrito Federal. 


\subsection{Panorama da produção orgânica}

De acordo com a Federação Internacional de Movimentos de Agricultura Orgânica IFOAM e o Instituto de Pesquisa da Agricultura - FIBL (2014), órgãos responsáveis em unir os certificados de qualidade no setor de orgânicos, existem 43,7 milhões de hectares de terras agrícolas que são manipulados por 2 milhões de produtores, atualmente 172 países relatam atividades de agricultura orgânica, sendo cadastrados no IFOAM 815 afiliadas de 120 países. A Tabela 1, a seguir demonstra os 10 países com maior área destinadas à agricultura orgânica.

Tabela 1 - Principais países produtores da agricultura orgânica.

\begin{tabular}{l|l|l}
\hline PAÍSES & ÁREA DE ORGẤNICOS (ha) & ÁRA AGRÍCOLA (\%) \\
\hline Austrália & 12 milhões & 2,93 \\
\hline Argentina & 3,6 milhões & 2,59 \\
\hline Estados Unidos & 2,1 milhões & 0,64 \\
\hline China & 1,9 milhões & 0,36 \\
\hline Espanha & 1,6 milhões & 6,4 \\
\hline Itália & 1,1 milhões & 9,12 \\
\hline Alemanha & 1 milhão & 6,19 \\
\hline França & 1 milhão & 3,76 \\
\hline Canadá & 833 mil & 1,23 \\
\hline Brasil & 705 mil & 0,27 \\
\hline Fon & 14, adaptado pelo autr. & \\
\hline
\end{tabular}

Fonte: Revista Exame (2014), adaptado pelo autor.

Os países com maiores níveis de manejo de terra agrícola são a Austrália, seguido da Argentina e os Estados Unidos (EXAME, 2014). A Austrália lidera o ranking devido à política do governo no desenvolvimento rural e no incentivo da exportação de seus produtos orgânicos, fornecendo também programas de promoção da agricultura orgânica, o qual oferta assistência técnica e treinamento aos produtores (EXAME, 2014; PORTAL CHILE ÁSIA PACIFICO, 2011).

O Brasil, mesmo em uma posição inferior, demonstra ser um país com um extenso espaço de crescimento, ocupando a décima colocação com 75 mil hectares e 0,27\% do total de área agrícola mundial. A Oceania é o continente com maior fatia de terra orgânica, o que correspondem $40 \%$ equivalente a (17,3 milhões de hectares), Europa com 27\% (11,6 milhões de hectares) da fatia de terra orgânica, seguida da América Latina com 15\% (6,8 milhões de hectares) (IFOAM \& FIBL 2014). O principal mercado de orgânico encontra-se nos Estados Unidos, com 27,1 milhões de euro, Alemanha com 7,9 milhões, seguido da França, com 4,8 milhões e, a China, com 3,7 milhões. A Índia registra 650 mil produtores orgânicos, país com 
maior número de produtores, segundo e terceiro lugar fica para a Uganda, com 190.552 mil produtores e, o México, com 169.703 mil produtores orgânicos. A Europa possui países como Áustria, Suécia e Suíça que apresentam os maiores percentuais do total de sua agricultura voltados para produção orgânica; o Brasil, mesmo em fase de crescimento, aparece em $93^{\circ}$ posição nesse ranking (IFOAM \& FIBL, 2014).

O mercado de produtos Brasileiros acompanha o crescimento mundial. Oferece vantagens como um vasto território, condição geográfica, climática, biodiversidade, abundância em água, e a aceitação do mercado consumidor. Apesar do mercado brasileiro apresentar vantagens estruturais ainda se faz necessário investimentos que promovam seu crescimento.

As regiões com mais produtores orgânicos são: Nordeste, com 4 mil, seguido pelo Sul, com 2.865 e, Sudeste, com 2.333 produtores. As regiões com maiores unidades de produção são o Nordeste, com 5.228, seguindo o Sul com 3.378 e o Sudeste com 2.228; no Centro Oeste são contabilizadas 592 unidades de produção (CODEPLAN. 2015). No Brasil atualmente existem oito organismos que atuam na certificação por auditória, sendo responsáveis em auditar o equivalente a $42,9 \%$ do total dos produtores orgânicos no país. O controle por meio do sistema participativo de garantia é exercido por 16 organizações de auditoria participativa, fiscalizando $28,2 \%$ dos produtores e o controle social na venda direta sem certificação atinge $28,9 \%$ dos produtores de orgânicos no país. Os estados com maiores estatísticas de certificação são: Paraná (1.233); Santa Catarina (1.059) Piauí com (935) seguidos pelo Rio Grande do Sul (874) e São Paulo com (786) produtores com certificações (CODEPLAN, 2015).

O Brasil possui uma área de produção orgânica 750 mil hectares, onde são produzidos: hortaliças, cana de açúcar, arroz, café, castanha do Brasil, cacau, açaí, guaraná, palmito, ovos, laticínios e sucos. Dados do Sebrae (2014) demonstram que o Brasil está se fortalecendo como produtor e exportador com mais de 15 mil propriedades certificadas sendo que $75 \%$ estão vinculadas a agricultura familiar, seus produtos são exportados para 76 países.

Os estados brasileiros acompanham o crescimento do país, por características como exigência do mercado consumidor e poder aquisitivo, capacidade produtiva, tecnologia, acesso a informação de plantio e manejo, um exemplo de estado em expansão nesse mercado é o Distrito Federal. Com grande participação no mercado de produtos orgânicos o Distrito Feral fornece seus produtos para um mercado consumidor exigente e fiel.

O Distrito Federal vem auxiliando o crescimento do Brasil no mercado de orgânicos, tendo registro entre as regiões brasileiras com maiores unidades de produção e sendo considerado um estado promissor no segmento de orgânicos; isso ocorre devido a renda per capita ser a maior do país, $\mathrm{R} \$ 2.034,00$ (dois mil e trinta e quatro reais), onde consequentemente 
os consumidores dispõem de um maior poder de compra, o tamanho do território próximo ao cliente e o clima são fatores favoráveis para o aumento da produção (CODEPLAN, 2015). A maioria dos produtos orgânicos comercializados no DF é produzida pela agricultura familiar e vendidos principalmente em feiras; esse mercado movimenta cerca de $\mathrm{R} \$ 30$ milhões por ano. Atualmente estão cadastrados no MAPA 110 produtores e 114 pontos de venda de orgânicos. Entre esses pontos de vendas constam 60 supermercados, 24 feiras e 30 sacolões. (MARRA, 2015).

Em Brasília, apenas 26 dos 110 produtores possuem certificação por auditoria, o que corresponde a $23,6 \%$, sendo avaliados pelo organismo de inspeção e certificação - ECOCERT Brasil. Na categoria sistema participativo de garantia constam 20 produtores, o equivalente a 18,2\% dos 110 produtores, sendo auditadas pelo Sindicato dos Produtores Orgânicos do Distrito Federal - SINDIORGÂNICO/OPAC; essas duas formas de certificação estão aptas a comercializar seus produtos em supermercados, sites e lojas especializadas (CODEPLAN, 2015).

Já o controle social para venda direta sem certificação é o segmento que possui mais produtores no DF, cerca de 58,2\%, 64 produtores vendem seus produtos diretamente ao consumidor, sem o selo. O cultivo de alimentos orgânicos no Distrito Federal corresponde a 775 hectares, atualmente existem 140 propriedades certificadas (EMATER - DF, 2015).

Do total dos 110 produtores orgânicos do Distrito Federal cadastrados no MAPA, 26 utilizam o Ecocert como mecanismo de controle que realiza a certificação por auditória, 20 produtores são fiscalizados pelo SINDIORGÂNICO e certificados pelo sistema participativo e os demais produtores são fiscalizados pelos organismos: Grupo São Sebastião, OCS Planaltina, ASTRAF, Grupo Floresta e AGE, ambos utilizam como forma de certificação o controle social para venda direta.

Com a demonstração do crescimento no Mundo, Brasil e Distrito Federal com suas peculiaridades é importante ressaltar a importância econômica da produção de produtos orgânicos.

\subsection{Mercado de produtos orgânicos}

Mais de 50 bilhões de dólares por ano advêm do mercado orgânico no mundo. O Brasil, por sua vez, possui forte influência na produção de açúcar, soja, café, óleos, amêndoas, mel e frutas(BORGUINI; TORRES, 2006). Segundo estimativas do Instituto Biodinâmico de Desenvolvimento Rural (IBD), o mercado orgânico brasileiro movimentou 150 milhões de dólares em 1999, com 130 milhões provenientes de exportações. Um estudo realizado pela 
equipe do Banco Nacional de Desenvolvimento (BNDES) entre 2000 e 2001 ponderou que a produção orgânica brasileira tem o valor de mercado correspondente entre 220 milhões e 300 milhões de dólares, tendo as médias de produtividade e preços de 2001 como referência.

Mais de 50 produtos advindos da agricultura orgânica, certificados, in natura ou processados, representam no Brasil, segundo a Associação de Agricultura Orgânica (AAO), $70 \%$ da produção nacional de alimentos orgânicos, possuindo maior concentração nos Estados de São Paulo, Minas Gerais, Espírito Santo, Paraná e Rio Grande do Sul (GAZETA MARCANTIL, 2000).

Buainain e Batalha (2007) relatam ainda que no Brasil, pequenos e médios empreendimentos representam $90 \%$ do total de produtores orgânicos, os quais possuem atuação basicamente no mercado interno. Os grandes estabelecimentos, em contrapartida, representam $10 \%$, em que a produção é direcionada a exportação. Empresas de grande porte fazem, em sua maioria, o processamento desse tipo de produto. Novos agentes estão aderindo neste setor, como os supermercados, segundo Blanc (2009).

A quantidade ainda pequena de produção de orgânicos no Brasil faz com que os preços referentes a esses produtos tenham valor, em média, entre $30 \%$ e $40 \%$ maiores que os produtos convencionais, fator influenciador no processo de compra, que por sua vez, possui forte ligação com expectativas, dentre outros fatores, quanto à aquisição de produtos livres de agrotóxico e adubos químicos, conforme mencionado por Stoltenborg (2011).

Diante de um mercado consumidor que demonstra uma tendência de crescimento em todo o mundo, passa a ser necessário analisar quais são as características determinantes que motivam o consumidor a escolher produtos orgânicos. Frente a tendência de crescimento é importante explanar sobre o conceito e principais especificidades de comportamento do consumidor.

\subsection{Agregação de valor e valor de mercado}

O objetivo do estudo do comportamento do consumidor é entender os motivos da compra, em uma análise detalhada dos processos e mecanismos que estão relacionados ao ato de comprar para uso próprio, sem a intenção de revender ou utilizar como bem de transformação (CHURCHILL JR.; PETER, 2012). O momento de compra é celebrado a partir da interação dinâmica entre as perspectivas que envolvem o ser humano, em uma perspectiva de afeto e cognição, ambiente e comportamento, em uma atitude relacionada a uma troca (OSLON; PETER, 2009). 
As empresas desenvolvem estratégias que podem influenciar a compra de produtos e serviços de acordo com a sensibilidade de cada consumidor. As estratégias utilizadas pelas empresas buscam a satisfação das necessidades dos clientes e sua fidelização por meio de produtos e serviços de qualidade (MOWEN; MINOR, 2003). O processo de compra está relacionado a satisfação de uma necessidade ou desejo, isto é, utilizando a ideia de que o estímulo às compras é dado pelo desejo de satisfação das necessidades, em que estas devem estar subordinadas ao pensamento de que se são naturais do consumidor ou se são determinadas por algum estímulo do ambiente (SOLOMON, 2011; KARSAKLIAN; 2013).

Caso uma empresa consiga desenvolver produtos ou serviços que atinjam ou até superem as expectativas dos compradores, haverá um sentimento de satisfação, que pode originar a fidelização de clientes (KOTLER, 1998; SOLOMON, 2011). A satisfação das necessidades dos consumidores está diretamente ligada a fatores intrínsecos, pessoais, como seus hábitos de consumo, experiências, personalidade, em conjunto com fatores extrínsecos, que não dependem do consumidor, como meio social e fator ambiental (MOWEN; MINOR, 2003; CHURCHILL JR.; PETER, 2012).

A presença de pessoas, grupos, amigos, familiares e conhecidos podem limitar ou estimular uma compra (MOWEN; MINOR, 2003). Logo, o ambiente social equivale as interferências feitas por agentes como grupos de pessoas, conhecidos ou não, que podem interferir diretamente na compra de alguém (URDAN; URDAN, 2010), incidindo nas formas de cultura, sociedade, classe socioeconômica, grupos de referência e status.

Já o fator ambiental diz respeito a aspectos estruturais do ambiente interno e externo de uma área de compra. Evidencia-se fatores relacionados a comodidade, praticidade correlacionados com estado de espírito do consumidor final e influências como a localização, disponibilidade de estacionamento, proximidade com os interesses do consumidor, organização de loja, os quais podem ser fatores decisivos no momento de escolha de um produto. Os fatores ambientais podem influenciar o comportamento do consumidor, os autores elencam os estímulos sensitivos, como tato, olfato, visão e paladar, que são utilizados como estratégias para influenciar vendas, tais como cor, ruído, iluminação interna e externa, limpeza da loja, clima; ou fatores relacionados ao estado emocional do consumidor como o layout da loja, com o fluxo organizado de pessoas e disposição dos objetos, percepção e sensação de segurança, estacionamento próximo e amplo, que podem acarretar no aumento ou diminuição da compra. (MOWEN; MINOR, 2003)

Os estímulos sensoriais podem ser um ponto importante no momento de compra, já que podem motivar o comportamento daqueles que os percebem. Tais estímulos estão ligados aos 
cinco sentidos do ser humano, ou seja, visão, audição, olfato, paladar e tato. As pessoas recebem uma grande quantidade de estímulos do ambiente, é impossível analisar e racionalizar todos eles, assim, o cérebro cria uma espécie de seleção do que se quer perceber (MOWEN; MINOR, 2003; SOLOMON, 2011).

Cabe ainda comentar a respeito das influências de marketing sobre o processo de compra, que abrangem a integralização de questões táticas (URDAN; URDAN, 2010). Os estímulos provenientes do marketing mix, ou composto de marketing, são advindos das estratégias criadas para oportunizar intercâmbios lucrativos entre vendedores e consumidores em virtude de aspectos como produto, preço, distribuição ou promoção, haja vista que podem intervir no processo em variados estágios (CHURCHILL JR.; PETER, 2012).

A partir da descrição das características do comportamento do consumidor e das estratégias de marketing utilizadas para agregar valor, faz-se necessário a apresentação dos conceitos relacionados a institucionalização de uma cooperativa. Cooperativa, como conceito, pode ser entendida como modelo organizacional, que surge de um grupo de pessoas que se unem com o mesmo objetivo (CAMARGO, 1960; FLEURY, 1983; RIOS, 1976).

O surgimento das primeiras cooperativas de consumo se baseavam no compartilhamento em grandes armazéns de itens como: azeite, açúcar, leite, com objetivo de garantir a sobrevivência de grupo de pessoas, em um período de grande crise econômica, com grande número de desempregados no ano de 1984, Inglaterra. (MLADENATZ, 1969). Essas cooperativas possuíam como características a livre adesão e saída dos associados, democracia dos direitos e deveres, compras e vendas à vista na cooperativa, retorno proporcional e operações com terceiros.

As cooperativas de consumo de produtos orgânicos são, atualmente, consideradas como uma forma percebida pelos consumidores para superarem, principalmente, insatisfação para com um produto, isto é, quando no momento pós-compra não houve geração de valor, advindos dos produtos orgânicos, alterando, assim, o quadro convencional da cadeia de consumo (KLUTH et al., 2011; MOURA et al., 2010; KLEIN, 2014).

É possível entender que as cooperativas de consumo de produtos orgânicos procuram satisfazer necessidades em comum, como a realização de compras unificadas, em quantidades maiores, tendo em vista, o contato direto com produtores. (ORGÂNICOS E SUSTENTÁ VEIS, 2008).

Essas cooperativas têm alimentos considerados mais saudáveis, sobretudo, sustentáveis, trazendo, ainda, relação de benefício mútuo entre produtores e consumidores, considerando que 
pelo fato de ter-se uma cadeia curta, o produtor possui remuneração melhor e o consumidor adquire produtos a preços menores do que se obtidos em estabelecimentos convencionais.

Para o desenvolvimento de uma cooperativa de consumidores de produtos orgânicos é necessário apresentar a descrição do funcionamento dessa cooperativa, para isso será elaborado neste trabalho um plano de negócios que visa evidenciar todas as características de uma empresa. Demonstra seu funcionamento a partir de uma análise interna e externa que envolve a cooperativa, como o demonstrativo financeiro, contábil, mercadológico.

\section{MÉTODO}

O objetivo da pesquisa é ser instrumento para busca de informações que possam contribuir com a sociedade, promover informações que sejam uteis à coletividade (SANTOS 2016). A partir do planejamento da pesquisa, formação de hipóteses, coordenação da investigação e interpretação de resultados é possível formular uma pesquisa que tenha validade científica (FACHIN;2002). O conhecimento descrito nessa pesquisa forma um conhecimento científico e real, onde é possível verificar a presença de uma sua sistemática, possui características que retratam uma realidade e é replicável a partir da repetição de seu método (LAKATOS; MARCONI, 2011).

A metodologia deste trabalho é caracterizada por cinco tópicos principais, devidamente explicados e caracterizados para a validação do método utilizado, sendo eles: descrição da pesquisa, a caracterização da região e local das pesquisas, caracterização dos consumidores e canais de distribuição, identificação da amostra e instrumento de coleta de dados.

\subsection{Descrição da pesquisa}

A pesquisa pode ser classificada mediante duas perspectivas, sendo elas: quanto ao objetivo e quanto aos procedimentos técnicos (SANTOS, 2016). Quanto aos procedimentos técnicos é classificada como descritiva, pois busca aprofundar características já existentes em determinada população (CRESWELL, 2010; SANTOS, 2016).

Como procedimento técnico para aprofundar os objetivos propostos neste estudo utilizouse pesquisa bibliográfica, que se caracteriza por um conjunto de obras reunidas com objetivo de formar evidencias sobre determinado assunto (FACHIN; 2002; SANTOS, 2016). Inicialmente foi realizada uma pesquisa em artigos, livros, revistas e em trabalhos acadêmicos na busca por informações específicas sobre produtos orgânicos, aspectos de legalidade, abrangência e tendências mundiais, nacionais e regionais no mercado de consumo, além de 
temas relacionados ao estudo de canais de comercialização de produtos orgânicos (SANTOS, 2016; LAKATOS; MARCONI; 2011).

A pesquisa foi dividida em três partes: a primeira parte da pesquisa, buscou avaliar o nível de satisfação e os fatores que influenciam o comportamento do consumidor no momento da compra de produtos orgânicos no Distrito Federal, a segunda parte da pesquisa buscou avaliar os canais de comercialização de produtos orgânicos do Distrito Federal, e a terceira parte da pesquisa avaliou a percepção dos steakholders frente a um novo modelo de comercialização de produtos orgânicos, uma cooperativa de consumidores de produtos orgânicos no Distrito Federal.

\subsection{Caracterização da região e local de estudo}

Considerou-se a população da pesquisa sendo os consumidores de produtos orgânicos de Brasília (DF). Após os ajustes do pré-teste, disponibilizou-se os questionários em meio digital, em duas redes sociais dos pesquisadores envolvidos no estudo. Os questionários permaneceram online para preenchimento durante o período de março de 2016 até dezembro de 2016. A amostra é classificada como sem reposição, pois cada respondente preencheu apenas uma vez o questionário, e, acidental, uma vez que foi inicialmente composta por pessoas conhecidas e, posteriormente, outras indicadas por elas que morassem em Brasília (SPIEGEL, 1997; RICHARDSON; PERES; WANDERLEY; CORREIA; PERES, 2010).

\subsection{Caracterização dos consumidores e agentes de comercialização}

A pesquisa de nível de satisfação e de fatores que influenciam o consumidor no momento de compra de produtos orgânicos, tem como objetivo mensurar o nível de satisfação dos consumidores de produtos orgânicos e evidenciar as principais variáveis que influenciam o consumidor no momento da compra.

A segunda pesquisa diz respeito a competitividade dos canais de comercialização de produtos orgânicos no Distrito Federal. A pesquisa foi elaborada com objetivo de se ter um panorama das atuais formas de comercialização de produtos orgânicos no Distrito Federal. A pesquisa tem por base a avaliação das variáveis mercadológicas de cada canal de venda de produtos orgânicos, que interferem no momento de compra dos consumires, dispondo de dados comparativos entre as formas de comercialização.

A terceira parte da pesquisa está relacionada ao cumprimento do objetivo específico quanto à avaliação da percepção dos steakholders diante da viabilidade de uma cooperativa de produtos orgânicos no Distrito Federal. A pesquisa foi elaborada a partir de um roteiro de 
entrevistas que busca perceber qual a avaliação frente a um novo modelo de negócios, e avaliar a partir dessas informações a possibilidade de implementação de uma cooperativa de consumidores de produtos orgânicos no DF.

\subsection{Instrumentos de coleta de dados}

Para a primeira parte da pesquisa elaborou-se um questionário com 17 (dezessete) questões, dividido duas partes, em 8 (oito) seções. O questionário avalia dois principais públicos, os consumidores de produtos orgânicos e os não consumidores de produtos orgânicos. Evidenciase como importante questionar os não-consumidores de produtos orgânicos em virtude de motivos de insatisfação, ou seja, não consomem em virtude de não se sentirem satisfeitos, e apresentarem motivos importantes para essa pesquisa. Procedeu-se um pré-teste do instrumento de coleta de dados com objetivo de saber se havia alguma distorção ou incompreensão das perguntas presentes no questionário. Este foi distribuído para 10 respondentes, em forma impressa, nos dias 14 e 16 do mês de março de 2016, no Centro Universitário Iesb, Campi Asa Norte, para alunos do curso de graduação em administração. A escolha deste lugar se deu pela conveniência, facilidade de acesso do pesquisador, e pela heterogeneidade dos entrevistados. Como resultado do pré-teste, fez-se necessário a diminuição do questionário, e o ajuste em algumas variáveis para tornar a interpretação mais fácil.

Para a segunda parte da pesquisa elaborou-se um questionário com 18 (dezoito) questões, dividido em 4 (quatro) partes, em 8 (oito) seções. Este questionário também avalia dois tipos de público, os consumidores de produtos orgânicos e os não consumidores de produtos orgânicos, justamente para saber os motivos que limitam a compra de um nãoconsumidor de orgânicos. Para esse questionário não se aplicou pré-teste.

A primeira parte do questionário levantou características sociodemográficas do consumidor composta por sete perguntas que buscaram caracterizar a amostra, delimitando características como: gênero, estado civil, grau de escolaridade, número de filhos, faixa etária e renda. Uma pergunta que divide os entrevistados em consumidores e não consumidores de produtos orgânicos. Os que não são consumidores de orgânicos são questionados o porquê de não consumirem. Aqueles que são consumidores de produtos orgânicos são direcionados a responder o motivo, a frequência, o gasto mensal, o principal tipo de produto consumido, e o local de consumo. Ao responder o local de consumo os entrevistados são direcionados a responderem sobre as variáveis que interferem no momento de compra naquele local escolhido. Os dados serão analisados por meio de um programa de análise multivariada denominado R, versão 3.2.5, data de atualização 14/04/2016, e em complemento o sistema Microsoft Excel. 
A terceira parte da pesquisa utiliza como ferramenta para coleta de dados um roteiro de entrevistas, disponível no apêndice. As entrevistas aconteceram no mês de março de 2017. Os entrevistados foram escolhidos a partir do seu envolvimento com o mercado orgânico, conhecimento técnico e experiência junto a produção e comercialização de produtos orgânicos. Nesta entrevista foram entrevistados o responsável pela coordenação de produção orgânica do Distrito Federal do órgão da EMATER- DF, o gestor de projetos de Agricultura Orgânica e analista da Unidade de Agronegócios do SEBRAE-DF; o produtor, ex-presidente da Associação de Produtores de produtos orgânicos do Distrito Federal; e o presidente e agricultor de tomates orgânicos da Associação Agro-Orgânica.

A entrevista foi feita individualmente, e sem restrição de tempo, e no lugar de preferência dos entrevistados. Todos os entrevistados conseguiram expor suas opiniões em todas as questões levantadas. A entrevista foi dividida em duas partes: a primeira parte feita pelo interlocutor com a apresentação do plano de negócios da cooperativa de consumidores de produtos orgânicos do DF, a segunda parte foram feitas 8(oito) indagações diretas, e a abertura para livre opinião, dúvida ou observação. De todas as entrevistas realizadas (02) foram gravadas por áudio e anotações em um caderno de registros, (01) áudio, vídeo e caderno de registros, e (01) apenas caderno de registros. A média de tempo de cada entrevista foi de 1 hora e 40 minutos, desde a apresentação da ideia até a finalização da entrevista.

\subsection{Identificação da amostra e análise estatística}

Diante da restrição financeira, tempo disponível e a grande dimensão da população de consumidores de produtos orgânicos e canais de comercialização optou-se por trabalhar com amostragem da população. Diante de uma grande população torna-se indispensável a determinação de uma amostra, o uso de técnicas e procedimentos que minimizem possíveis vieses e distorções que limitem a legitimidade, e comprometam a cientificidade e credibilidade da investigação (SANTOS;2016).

Para o cálculo do tamanho da amostra, considerou-se a fórmula de determinação de Martins (2002) para população finita: Onde: n é o tamanho da amostra a ser selecionada da população; $\mathrm{Z}_{\mathrm{c}}$ corresponde à abscissa da normal padrão:

$$
n=\frac{z_{c}^{2} \cdot p \cdot q}{d^{2}}
$$

Onde: $\mathrm{n}$ é o tamanho da amostra a ser selecionada da população; $\mathrm{z}_{\mathrm{c}}$ corresponde à abscissa da normal padrão n (para construção do intervalo de confiança); d representa erro amostral expresso em decimais (máxima diferença que o investigador admite suportar); p é a estimativa 
da proporção; e q representa 1 - p. No presente estudo, o nível de precisão foi de 0,5 pontos, sendo que o intervalo de confiança é de $95 \%$ e o valor de $\mathrm{z}=1,96$ (teste $\mathrm{Z}$ ). Participaram da pesquisa 346 respondentes.

\section{RESULTADO E DISCUSSÃO}

O mercado de produtos orgânicos é complexo e precisa ser analisado por vários aspectos, como: perfil deste consumidor (gênero, estado civil, escolaridade, idade e renda), a frequência de compra, os fatores que influenciam sua escolha, o lugar onde estes produtos são adquiridos, o nível de satisfação com a atual forma de comercialização, as possíveis reclamações feitas no ambiente de compra, o interesse em participar de uma cooperativa de consumidores, os diferenciais competitivos oferecidos pelas atuais formas de comercialização, o gasto mensal e o tipo de produto mais consumido. Essas são questões discutidas nesse trabalho.

Para garantir os objetivos desta pesquisa preferiu-se analisar o mercado de produtos orgânicos em dois momentos, sobre duas ópticas, sendo a primeira: analisar o consumidor especificamente, com foco na compra, e a segunda análise com foco voltado para o mercado, a troca em si, com objetivo de analisar a fundo todo o ambiente de comercialização de produtos orgânicos no Distrito Federal, e mensurar o real interesse dos consumidores em novas formas de venda.

Neste capítulo analisou-se o mercado orgânico sobre duas perspectivas, sendo elas: o nível de satisfação dos consumidores de produtos orgânicos e a competitividade do mercado de produtos orgânicos no Distrito Federal.

\subsection{Pesquisa Nível de satisfação dos consumidores de produtos orgânicos}

\subsubsection{Dados Demográficos}

A análise demográfica reuniu dados da pesquisa em duas categorias: consumidores de produtos orgânicos e não consumidores de produtos orgânicos distribuídos por categorias demográficas (gênero, estado civil, grau de escolaridade, idade e renda). As proporções percentuais dos dados demográficos foram exploradas sob duas perspectivas, a análise entre consumidores e não consumidores de produtos orgânicos em suas variáveis demográficas, e a análise entre suas próprias categorias, também foram feitas demonstrando o número absoluto de respondentes e sua representação percentual. 


\subsubsection{Gênero}

É possível observar que o gênero feminino corresponde a 67,3\%, enquanto o gênero masculino corresponde a 32,7\% de todos os consumidores de produtos orgânicos da amostra. Versiani (2016) ao investigar a percepção dos consumidores de orgânico no DF, em uma pesquisa realizada no CEASA-DF, concluiu que a maioria dos consumidores de alimentos orgânicos, frequentadores CEASA-DF, pertencem ao gênero feminino, sendo representado por $60 \%$ de mulheres e $40 \%$ de homens. Para Vilela et al (2006), que determinou o perfil dos consumidores de produtos orgânicos no Distrito Federal, em pontos específicos de comercialização na cidade de Brasília, 51\% dos entrevistados são mulheres, e 49\% homens.

A predominância do gênero feminino está ligada a presença do número de mulheres no ambiente de compra, e não está restrito ao Distrito Federal, como afirma Trevizan e Casimiro (2009), em sua pesquisa sobre consumidores de produtos orgânicos em Vitória da Conquista na Bahia. Nesta pesquisa as mulheres são mais influentes que os homens no ambiente de compra, e estão presentes como mães, esposas, filhas ou mulheres, e segundo os autores, são $61 \%$ dos consumidores de produtos orgânicos. Assim como Moraes et al (2014), em sua análise sobre o perfil do consumidor de produtos orgânicos de Campo Grande - MS, que demonstra que 63\% são do gênero feminino e $37 \%$ do gênero masculino. Sendo estes resultados semelhantes ao encontrado no presente trabalho.

No trabalho realizado nesta pesquisa, a análise em uma mesma categoria demonstra que $65,7 \%$ de todas as mulheres entrevistadas são consumidoras de produtos orgânicos, e apenas $34,3 \%$ não consomem. O gênero masculino tem uma distribuição mais igualitária onde 51,1\% dos homens consomem e 48,9\% não consomem produtos orgânicos para esta amostra.

\subsubsection{Estado Civil}

De acordo com o estado civil observa-se que os consumidores de produtos orgânicos e não consumidores de produtos orgânicos se dividem em Solteiros, Casados, Divorciados e Viúvo. Desta amostra os consumidores de produtos orgânicos correspondem a 65,4\% solteiros, $29,3 \%$ casados 4,8\% divorciados, $0,5 \%$ viúvo. A amostra de Versiani (2016), evidencia um cenário diferente com (48\%) casados, e relatam consumir produtos orgânicos por ser melhor para ambos, e por influenciar de forma adequada a alimentação de seus filhos. É importante ressaltar que a amostra apresentada pela autora tem idade relativamente maior, ou seja $30 \%$ de sua amostra tem idade entre 50 e 60 anos. Assim como Moraes et al (2014) que concentra sua pesquisa em uma amostra de casados, que representam 53\% de toda sua amostra, e justificam 
o consumo de produtos orgânicos por considera-los melhores e saudáveis, os solteiros, com $40 \%$, dizem consumir com uma menor frequência, já divorciados $(5 \%)$ e viúvos (2\%) atribuem o consumo à saúde.

Os não consumidores de produtos orgânicos divididos por estado civil correspondem a $68,8 \%$ de solteiros, $26,8 \%$ de casados e $4,3 \%$ de divorciados e nenhum viúvo. A análise de uma mesma categoria demonstra que 58,9\% dos solteiros consomem produtos orgânicos, e 41,1\% dos solteiros não consomem produtos orgânicos. A análise feita entre os casados é possível observar que 62,2\% dos casados consomem produtos orgânicos e 37,8\% dos casados não consomem produtos orgânicos. Dos divorciados, 62,5\% são consumidores de produtos orgânicos, e 37,5\% não consomem produtos orgânicos. E o único viúvo é consumidor de produtos orgânicos.

\subsubsection{Nível de escolaridade}

Ao se tratar de consumidores de produtos orgânicos é possível observar que 1,4\% da amostra possui ensino médio incompleto, $4,8 \%$ possuem ensino médio completo, 37,5\% possuem ensino superior incompleto, $33,7 \%$ possuem ensino superior completo, $18,8 \%$ são pósgraduados e 3,8\% possuem doutorado. A amostra de Vilela et al (2006) demonstra que boa parte da sua amostra de consumidores de produtos orgânicos é esclarecida, e $86 \%$ deles possuem nível superior, assim como o comprovado pela pesquisa da Versiani (2016), que evidencia que produtos orgânicos são adquiridos por consumidores com maior grau de escolaridade, influenciados por uma rotina intensa de trabalho que demandam maior preocupação com a qualidade e segurança dos alimentos. Moraes et al (2014) também correlaciona o nível de instrução ao consumo de orgânicos e apresenta que $43 \%$ de sua amostra de consumidores de orgânicos possui nível superior completo.

Ao se analisar o nível de escolaridade e confrontar os consumidores e não consumidores de produtos orgânicos destaca-se que os entrevistados que possuem ensino médio incompleto $75 \%$ consomem produtos orgânicos e $25 \%$ não consomem, aqueles que possuem nível médio completo 58,8\% consomem produtos orgânicos e 41,2\% não consomem, com superior incompleto $53,1 \%$ consomem e 46,9\% não consomem, ensino superior completo $65,4 \%$ consomem e 34,6\% não consomem, com pós-graduação 68,4\% consomem e 31,6\% não consomem, e aqueles que possuem doutorado $72,7 \%$ consomem e $27,3 \%$ não consomem. Ao contrário, os que não consomem produtos orgânicos, $0,7 \%$ possuem ensino médio incompleto, 
$5,1 \%$ possuem ensino médio completo, $50 \%$ ensino superior incompleto, 26,8\% superior completo, $13 \%$ são pós-graduados e $2,2 \%$ possuem doutorado.

\subsubsection{Faixa Etária}

Quanto a faixa etária dos consumidores de produtos orgânicos é possível observar que: $38,9 \%$ estão na faixa de 18-25 anos, 51,4\% estão entre $26-45$ anos, 8,7\% correspondem a faixa de 45-65 anos, 1,0\% mais de 65 anos de idade.

Ao se analisar aqueles que não consomem produtos orgânicos de acordo com sua faixa etária, observa-se que 50\% concentram-se na faixa etária de 18-25 anos, 44,2\% entre 26-45 anos, 5,1\% entre 46-65 anos e 0,7 com mais de 65 anos. A análise de cada faixa etária nas categorias de consumidores ou não de produtos orgânicos apresentam os seguintes dados: entre 18-25 anos 54\% consomem enquanto $46 \%$ não consomem, de $26-45$ anos $63,7 \%$ consomem e $36,3 \%$ não consomem, entre 46-65 anos $72 \%$ consomem e $28 \%$ não consomem, com mais de 65 anos $66,7 \%$ consomem e 33,3 não consomem produtos orgânicos.

\subsubsection{Renda}

Quando analisada a renda dos entrevistados pode-se afirmar: $26,4 \%$ recebem menos que $\mathrm{R} \$ 2000,00,28,4 \%$ recebem entre $\mathrm{R} \$ 2001,00$ e $\mathrm{R} \$ 4.000,00$ reais, 11,5\% recebem entre $\mathrm{R} \$ 4001,00$ e $\mathrm{R} \$ 6000,00$ e 6,3\% tem faixa salarial que varia entre $\mathrm{R} \$ 6001,00$ e $\mathrm{R} \$ 8.000,00$, $8,2 \%$ com faixa de $\mathrm{R} \$ 8.000,01$ até $10.000,00,9,6 \%$ apresentam renda superior a $\mathrm{R} \$ 10.000,00$, e 9,6\% optaram por não responder. Vilela et al (2006) avaliou uma amostra de consumidores de produtos orgânicos com renda mensal alta, onde $88 \%$ da amostra recebia 13 salários mínimos, e 27\% com mais de 30 salários mínimos. Semelhante ao apresentado por Moraes et al (2014), onde 44\% de seus entrevistados possuem renda de 6 a 10 salários mínimos, e $15 \%$ possuem renda maior que 10 salários mínimos.

Quando analisada a amostra daqueles que não consomem produtos orgânicos é possível observar que 46,4\% recebem menos do que $\mathrm{R} \$ 2000,00,20,3 \%$ recebem entre $\mathrm{R} \$ 2001,00$ e $\mathrm{R} \$ 4.000,00$ reais, 4,3\% recebem entre $\mathrm{R} \$ 4001,00$ e $\mathrm{R} \$ 6000,6,5 \%$ tem faixa salarial $\mathrm{R} \$ 6001$ e $\mathrm{R} \$ 8.000,00,1,4 \%$ tem renda de $\mathrm{R} \$ 8.000,01$ até $10.000,00,4,3 \%$ apresenta renda superior a $\mathrm{R} \$ 10.0000$ e $16,7 \%$ preferiu não responder a está pergunta.

Quando se analisa as faixas de renda e o consumo ou não de produtos orgânicos é possível observar que: com renda de menos de $\mathrm{R} \$ 2.000$ 46,2\% consomem e 53,8\% não consomem produtos orgânicos, com faixa de $\mathrm{R} \$ 2.001-\mathrm{R} \$ 4.000$ observa-se que $67,8 \%$ 
consomem e 32,2\% não consomem, entre $\mathrm{R} \$ 4.0001$ e $\mathrm{R} \$ 6.00080 \%$ consomem e $20 \%$ não consomem, $\mathrm{R} \$ 6.001-\mathrm{R} \$ 8.000$ 89,5\% consomem e 10,\% não consomem, com faixa salarial acima de $\mathrm{R} \$ 10.00076,9 \%$ consomem e $23,1 \%$ não consomem, daqueles que preferiram não responder sua renda 46,5\% consomem produtos orgânicos e 53,5\% não consomem.

\subsubsection{Distribuição dos motivos de não consumir produtos orgânicos}

Aqueles entrevistados que após descreverem suas características demográficas foram direcionados a responder se consomem ou não produtos orgânicos. De 346 respondentes, 208 respondentes, o que correspondente a $60,1 \%$ de toda amostra, disseram consumir produtos orgânicos. Já 138 respondentes, o equivalente a 39,9\% da amostra, disseram não consumir produtos orgânicos.

Em uma análise aprofundada os principais fatores que influenciam os respondentes a não consumirem produtos orgânicos estão preço alto $(52,2 \%)$ e dificuldade em encontrar produtos de sua preferência (21\%). Versiani (2016) aponta resultados similares, $48 \%$ dos entrevistados evidenciaram o preço do produto orgânico como elevado, e logo em seguida, a pouca diversidade (23\%) de produtos orgânicos. Conhecer os produtos orgânicos $(10,9 \%)$ e não perceber diferença entre os produtos orgânicos e convencionais $(10,9 \%)$ são outros fatores apresentados nesta pesquisa.

Já os motivos como: dificuldade de encontrar produtos orgânicos e o alto preço $(0,7 \%)$, acesso aos produtos $(0,7 \%)$, dificuldade em encontrar $(0,7 \%)$, hábito alimentar $(0,7 \%)$, falta de interesse $(0,7 \%)$, não perceber qualidade nos produtos $(0,7 \%)$, o produto é relativamente caro quando não se acredita que o produto é orgânico, foi opção escolhida apenas por 01 respondente.

Em pesquisa realizada pela Embrapa (2006), é possível observar uma evolução quanto aos pontos de venda e os acessos aos produtos orgânicos, em pesquisa anterior $73 \%$ dos consumidores disseram que são poucos pontos de venda, e que não é possível consumir apenas produtos orgânicos em virtude de sua baixa oferta no mercado, mostrando uma evolução do cenário comparado ao atual.

\subsubsection{Fatores relacionados ao consumo de produtos orgânicos}

Aos respondentes que disseram consumir produtos orgânicos, após descreverem suas características sócio demográficas, foram questionados sobre qual principal motivo que você prioriza no momento de compra de um produto orgânico. 
Essa pergunta foi disponibilizada em uma Escala de Likert, ferramenta psicométrica com graus de importância, que variam desde sem importância, pouco importante, importante, muito importante e extremamente importante, com os seguintes fatores: Aparência/Aspecto Visual, Saúde, Sabor, Riqueza nutricional, Selo de responsabilidade social, Selo de responsabilidade ambiental, Preço, Influência de Família/Amigos, Influência da mídia, Origem do produto (confiança), Disponibilidade do produto.

A classificação foi feita por uma média ponderada, que leva em consideração o número de vezes que cada variável foi escolhida e o peso da classificação, sendo possível classificar com grau de importância cada variável.

É possível observar que os fatores que geralmente os consumidores orgânicos do Distrito Federal levam em consideração, em ordem de prioridade, no momento da compra são: Saúde $(4,27)$, Riqueza Nutricional $(4,06)$, Sabor $(4,01)$, Aparência/Aspecto Visual $(3,73)$, Origem do Produto (confiança) (3,57), Selo de Responsabilidade ambiental $(3,53)$, Preço $(3,48)$, Disponibilidade do Produto $(3,42)$, Selo de Responsabilidade social $(3,39)$, Influência de Família/Amigos (2,34), Influência da Mídia (1,93).

Os fatores que mais influenciam a decisão do consumidor em escolher produtos orgânicos, para esta amostra, é a preocupação com a saúde, Versiani (2016) reafirma esse posicionamento, onde em sua pesquisa, $82 \%$ dos entrevistados consomem produtos orgânicos em função da preocupação com saúde, associado a saúde própria e da família, principalmente aqueles que possuem filhos. Trevizan e Casemiro (2009) também apontam o posicionamento do consumidor de produtos orgânicos e sua relação com saúde, $63 \%$ de sua amostra associam o produto orgânico a um alimento mais saudável. Reconhece-se que esta variável tem relação direta com a preocupação com a riqueza nutricional presente nos produtos orgânicos, que representa a segunda maior prioridade do consumidor no momento de compra, conforme relata Ormond; Paula; Filho; Rocha (2002).

O sabor é o terceiro maior influenciador do consumidor na decisão do consumidor de produtos orgânicos, seguido pela aparência/aspecto visual. Características relacionadas aos órgãos do sentido: paladar e visão. Trevizan e Casemiro (2009) afirmam que 39\% de sua amostra associa os produtos orgânicos a produtos saborosos.

A confiança sobre a origem do produto; ter ciência se o produto é realmente orgânico ou não, é uma variável decisiva no momento de escolha do consumidor. Variável importante levada em consideração no momento de sua decisão. Preocupação com a preservação ambiental, e uso racional dos recursos naturais com respeito a natureza, juntamente com o aspecto de confiança sobre a origem do produto é um fator que direciona o consumo 
(ORMOND; PAULA; FILHO; ROCHA, 2002). E é traduzido no momento da compra pelo selo de responsabilidade ambiental. Entretanto, Cerveira e Castro (1999) afirmam que grande parte da população não recebe informação sobre a metodologia de produção orgânica, em sua pesquisa apenas $2 \%$ tinha conhecimento sobre o assunto. Isso demostra que o Selo Orgânico, em forma de certificação, é um fator importante para gerar credibilidade aos consumidores. Trevizan e Casemiro (2009) apontam em sua pesquisa que 63\% dos entrevistados consideram o selo de produtos orgânicos essencial, gerando apelo ambiental e mercadológico, e $47 \%$ de sua amostra associam o selo de responsabilidade ambiental, por meio da preocupação em preservar a natureza, com produtos orgânicos. O selo de produtos orgânicos demonstra processos adequados de se plantar, cultivar e colher alimentos isentos de contaminação química, resguardando o consumidor de qualquer dano de fornecedores inescrupulosos (SEBRAE, 2010).

A variável Preço $(3,48)$ não é considerada de extrema relevância no momento de aquisição de produtos orgânicos. É uma variável intermediária que para esta amostra não é fator essencial. Muito se justifica em virtude da característica sociodemográfica dos respondentes, pelo grau de escolaridade, renda, faixa etária dos consumidores de produtos orgânicos. O mesmo foi constatado por Cerveira e Castro (1999), 82\% dos consumidores de produtos orgânicos tem consciência que o preço desses produtos é maior que os dos produtos convencionais e que os consumidores estão dispostos a pagar até 30\% a mais que o preço dos produtos convencionais. SEBRAE (2010) valida que os preços mais altos dos orgânicos estão relacionados ao local de compra, ao tipo de produto, aos maiores custos de mão de obra, insumos embalagens, a necessidade de certificação e as perdas no processo de produção, transporte e venda.

A disponibilidade do produto apresentou média de 3,42 se apresentando como um fator de pouca interferência no momento de compra. Os consumidores de produtos orgânicos em sua grande maioria respeitam as estações de colheita e plantio respeitando o tempo da natureza, a sazonalidade dos produtos, a disponibilidade de acordo com as épocas do ano. Porém vale ressaltar que parte dos consumidores que não encontram produtos de sua preferência podem migrar para o consumo de produtos convencionais. Em pesquisa realizada no Estado de São Paulo, observou-se que $61 \%$ adquire produtos convencionais por interrupção na oferta de produto similar orgânico. Amostra ainda diz que compram produtos convencionais pela maior praticidade e comodidade e apontaram a falta de maior variedade de frutas e produtos processados de origem orgânica (CERVEIRA, CASTRO; 1999). Versiani (2016) aponta que existe grande dificuldade em encontrar produtos orgânicos, principalmente frutas. 
O selo de responsabilidade social significa a importância dada as práticas de inclusão social implementadas na agricultura orgânica. É possível perceber que os consumidores não veem como fator determinante o selo de responsabilidade social, não sendo este um fator determinante para o processo de compra de produtos orgânicos. Trevizan e Casemiro (2009) apresentam uma amostra maior de consumidores que se preocupam com características que contemplam o selo de responsabilidade social, o equivalente a $20 \%$ de toda a amostra associa os produtos orgânicos a geração de empregos no campo.

Os fatores de grupo de referência influência de amigos e família são os últimos fatores de influência no momento de compra de produtos orgânicos. É possível observar que a compra de produtos orgânicos é tomada a partir de características individuais e pouco dependentes de grupos de consumo, os consumidores são formados a partir de vontades individuais adquiridas ao longo do tempo, com baixa interferência de amigos e família. A influência de amigos e família é considerada a menor influência em grau de importância frente todas as outras variáveis pesquisadas.

A marca dos produtos orgânicos não é um fator relevante quando se analisa as prioridades do consumidor no momento da compra. A marca passa a ser aspecto subjetivo de decisão. Demonstra-se como uma variável com 59\% sem importância, ou pouco importante para o consumidor no momento da compra. Menos da metade, ou seja, $41 \%$ demonstra que esta variável é importante, muito importante ou extremamente importante. Trevisan e Casemiro (2009) evidenciam que apenas $7 \%$ de sua amostra consideram a marca um fator essencial aos produtos orgânicos.

O fator influência da mídia faz parte do marketing mix, promoção. Sendo este considerado o menor fator de influência de todas as variáveis reunidas na pesquisa. O cliente não leva como fator decisivo os anúncios, tabloides, vinculação televisiva, anúncios no rádio ou qualquer outra forma de propaganda. O consumidor de produtos orgânicos demonstra ser pouco sensível a mídia ao escolher seus produtos orgânicos. Porém, na pesquisa de Moraes et al (2014) é possível observar que os consumidores buscam como meio de procurar informações na televisão (38\%), internet (37\%), jornal (15\%) e revistas $(7 \%)$.

\subsubsection{Nível de Satisfação (Ambiente)}

Os respondentes foram indagados sobre seu nível de satisfação em relação ao lugar onde fazem compras de produtos orgânicos, para cada fator o respondente apontava seu nível de satisfação, variando de insatisfeito, pouco satisfeito, satisfeito, muito satisfeito e extremamente 
satisfeito. As perguntas foram direcionadas ao ambiente de compra com intuito de averiguar quais fatores tem importância no momento de compra além dos produtos orgânicos. É possível perceber que os consumidores não são influenciados apenas pelo produto, mas também por um conjunto de variáveis que se relacionam com o momento de compra, dentre elas o ambiente de comercialização.

Foram evidenciadas as seguintes variáveis de escolha: sensação de segurança, limpeza no ambiente de compra, localização, formas e meios de pagamento, aparência e cortesia dos funcionários, conforto, variedade de produtos orgânicos, conhecer o produtor rural, descontos e promoções e marca conforme pode ser observado na Tabela 2. Mesmo assim é possível observar que as médias estão abaixo do esperado, em uma classificação de 0-5 pontos observase que os estabelecimentos têm média inferior a 3,5.

Tabela 2 - Nível de satisfação em relação ao ambiente de compra.

Qual seu nível de satisfação em relação ao ambiente que você compra produtos orgânicos?

\begin{tabular}{|c|c|c|c|c|c|c|}
\hline Fator & 1 - Insatisfeito & $\begin{array}{l}2 \text { - Pouco } \\
\text { satisfeito }\end{array}$ & 3 - satisfeito & $\begin{array}{l}4 \text { - Muito } \\
\text { satisfeito }\end{array}$ & $\begin{array}{c}5 \text { - Extremamente } \\
\text { satisfeito }\end{array}$ & $\begin{array}{c}\text { Nota } \\
\text { Ponderada }\end{array}$ \\
\hline Sensação de segurança no momento da compra & 8 & 24 & 104 & 41 & 31 & 3,30 \\
\hline Limpeza do ambiente de compra (gôndolas, freezeı & 6 & 33 & 95 & 41 & 33 & 3,30 \\
\hline Localização & 16 & 19 & 99 & 41 & 33 & 3,27 \\
\hline Formas/Meio de pagamento & 12 & 31 & 93 & 46 & 26 & 3,21 \\
\hline Aparência/Cortesia dos funcionários & 9 & 38 & 93 & 46 & 22 & 3,16 \\
\hline Conforto & 13 & 31 & 107 & 30 & 27 & 3,13 \\
\hline Variedade de produtos orgânicos & 23 & 46 & 84 & 34 & 21 & 2,92 \\
\hline Conhecer o produtor rural (conhecido, colega, amig & 16 & 60 & 78 & 36 & 18 & 2,90 \\
\hline Descontos e promoções & 34 & 73 & 62 & 23 & 16 & 2,59 \\
\hline Marca & 60 & 62 & 65 & 14 & 7 & 2,26 \\
\hline
\end{tabular}

Fonte: Elaborado pelo autor.

As variáveis relacionadas ao ambiente físico que os consumidores mais demonstraram satisfação está relacionada a sensação de segurança no momento de compra e limpeza do ambiente de compra, ambos com médias de 3,30. É possível observar que $15 \%$ de toda amostra se sente insatisfeito ou pouco satisfeito com a sensação de segurança no ambiente de venda, e 85\% apresentam nível de satisfação, sendo estes: satisfeitos, muito satisfeitos, extremamente satisfeitos. Em relação a limpeza de compra $20 \%$ sentem-se pouco satisfeitos ou insatisfeitos, $81 \%$ se sentem satisfeitos, muito satisfeitos ou extremamente satisfeitos. As variáveis evidenciadas pela pesquisa corroboram com aquilo que já havia sido discutido pela Embrapa (2006) onde as principais variáveis que influenciam a escolha do consumidor no momento de comprar são: a qualidade dos produtos, proximidade da residência, facilidade de aquisição, presteza no atendimento, maior gama de produtos oferecidos, higiene, maior variedade, praticidade e frescor.

A sensação de satisfação em relação a variável de marketing mix, praça demonstra que os consumidores se sentem satisfeitos com a localização dos estabelecimentos que costumam 
realizar suas compras (SOLOMON, 2011; KARSAKLIAN; 2013). A localização aparece como a $3^{a}$ maior média. Onde a grande maioria dos respondentes se dizem satisfeitos (99\%) quando questionados a respeito da localização, $83 \%$ de toda amostra se sente satisfeito, muito satisfeito ou extremamente satisfeito, enquanto $17 \%$ se sentem pouco satisfeitos ou insatisfeitos.

Ao analisar o nível de satisfação dos consumidores de produtos orgânicos em relação as formas de pagamento oferecidas são possíveis observar que a grande maioria dos respondentes se sentem satisfeitos. De todos aqueles que consomem produtos orgânicos $71 \%$ se sentem satisfeitos, muito satisfeitos ou extremamente satisfeitos, e $21 \%$ de toda amostra se sente insatisfeito ou pouco satisfeitos.

A aparência e cortesia dos funcionários é outra variável levada em consideração para determinação do nível de satisfação dos consumidores de produtos orgânicos. A pesquisa demonstra que $77 \%$ dos entrevistados se sentem satisfeitos, muito satisfeitos ou extremamente satisfeitos, já $23 \%$ se sentem insatisfeitos ou pouco satisfeitos. A média de consumidores que consideram um fator importante no momento de compra é 3,16, o que demonstra ser uma variável não determinante no momento de compra.

Conforto foi analisado levando em consideração um ambiente físico agradável para realização da compra de produtos orgânicos. Sentem-se satisfeitos 107 respondentes, o que equivale a $79 \%$ de clientes satisfeitos, muito satisfeitos e extremamente satisfeitos. E, $21 \%$ de todos os entrevistados se sentem insatisfeitos ou pouco satisfeitos com o conforto oferecido pelos estabelecimentos.

A variedade de produtos orgânicos foi apontada como um fator que geral insatisfação da amostra pesquisada, $33 \%$ de toda amostra considera que a variedade de produtos orgânicos é insatisfatória ou pouco satisfatória. Já $67 \%$ da amostra se considera satisfeito, muito satisfeito ou extremamente satisfeito. Cerveira e Castro (1999) apontam que o principal fator da insatisfação dos consumidores de produtos orgânicos em São Paulo é a falta de diversidade de frutas.

Conhecer o produtor rural gerou um índice de insatisfação ou pouca satisfação de $37 \%$ nos entrevistados. E, $63 \%$ de toda amostra se sente satisfeito, muito satisfeito ou extremamente satisfeito com ao conhecer o produtor rural. Isso demonstra que existe uma relativa proximidade entre o produtor rural e o consumidor, além de demonstrar que essa variável é importante para garantia do nível de satisfação dos consumidores de produtos orgânicos (RENTING; MARSDEN; BANKS, 2003).

Ao observar a relação existente entre descontos e promoções com nível de satisfação é possível perceber que mais da metade dos entrevistados se mostram insatisfeitos ou pouco 
satisfeitos, representando $51 \%$ de toda amostra, em número absoluto 73 entrevistados demonstraram pouca insatisfação. Satisfeitos, muito satisfeitos e extremamente satisfeitos são $49 \%$ de toda a pesquisa. Essa variável representa o segundo maior índice de insatisfação relacionada ao ambiente físico de toda amostra.

Diante dos questionamentos sobre variáveis que influenciam a decisão de compra de consumidores de produtos orgânicos questionou-se qual o local de compra que os consumidores geralmente fazem as compras de seus produtos orgânicos. O objetivo desta pergunta era saber especificamente em qual ambiente de compra concentra a maior demanda de consumidores. A comercialização de produtos orgânicos pode ser feita por meio de venda direta ao consumidor, ou por meio de agentes intermediários do varejo (SEBRAE;2010). Nesta pergunta foram disponibilizados os seguintes estabelecimentos: supermercado, feira de produtos orgânicos nas proximidades da casa do consumidor, hipermercado, empórios ou lojas especializadas, feira CEASA, restaurantes de produtos orgânicos, feira de produtos orgânicos na proximidade do trabalho e internet (sites) como demonstrado na Tabela 3.

Tabela 3- Locais de compra de produtos orgânicos no DF.

Onde você costuma comprar produtos orgânicos?
\begin{tabular}{|l|r|r|}
\hline & $N$ & \\
& & \\
& & \\
& & \\
\hline Supermercado & 120 & $57,69 \%$ \\
\hline Feira de produtos orgânicos - Proximidade de Casa & 88 & $42,31 \%$ \\
\hline Hipermercado & 76 & $36,54 \%$ \\
\hline Empórios/Lojas especializadas & 51 & $24,52 \%$ \\
\hline Feira - CEASA & 49 & $23,56 \%$ \\
\hline Restaurante de produtos orgânicos & 19 & $9,13 \%$ \\
\hline Feira de produtos orgânicos - Proximidade do trabalho & 17 & $8,17 \%$ \\
\hline Internet (Sites de produtos orgânicos) & 6 & $2,88 \%$ \\
\hline
\end{tabular}

Fonte: Elaborado pelo autor.

Ao observar os resultados da pesquisa contata-se que os consumidores costumam comprar produtos orgânicos preferencialmente em supermercados, sendo está preferência responsável por $57,69 \%$. Na pesquisa sobre o perfil de consumidores de orgânicos realizada pela Vilela et $\mathrm{Al}$ (2006) os dados apresentados são bem diferentes onde é possível observar que os locais de compra mais utilizados são as feiras (42\%) e as cestas entregues em domicílio (27\%). A participação dos supermercados (17\%) e da CEASA (14\%) como locais de aquisição de produtos orgânicos ainda era bem pequeno. 
Em algumas regiões administrativas no Distrito Federal acontecem feiras de produtos orgânicos, que proporcionam a divulgação e comercialização de produtos orgânicos nas proximidades das casas de alguns consumidores. As feiras geralmente acontecem semanalmente o que proporciona tempo hábil para abastecimento das famílias, em virtude disso é possível constatar que segundo lugar de maior frequência de compra são feiras orgânicas nas proximidades da casa dos consumidores. De todos os entrevistados $42,31 \%$ optam pela compra nas feiras nas proximidades de casa.

Os grandes hipermercados passaram a oferecer em seu portifólio produtos orgânicos, a variedade de produtos, marcas, fornecedores juntamente com a quantidade de lojas e a venda de produtos que não são orgânicos, mas são necessários para alguns consumidores, como, produtos de higiene e limpeza, bazar, mercearia. Além de infraestrutura como estacionamento, rampa de acessibilidade, carrinhos adaptados para idosos e deficientes, condição de pagamento, fazem do hipermercado uma opção com grande 36,54\% da preferência de compra. O Grupo Pão de Açúcar, que detém marcas como Pão de Açúcar e Extra, aumentou seus investimentos na diversificação de seu portfólio de produtos orgânicos, incluindo bebidas orgânicas, e apresentou aumento de 29,3\% nas vendas de 2009 para 2010 (IPD, 2011)

O número de lojas especializadas passou a ser explorado como nicho de mercado lucrativo. A presença de lojas especializadas em produtos orgânicos em Brasília passa a oferecer vantagens como a proximidade com a casa, trabalho ou lugar onde estudam, e acabam por oferecer uma maior gama de produtos. Os empórios ou lojas especializadas em produtos orgânicos representam 24,52\% dos estabelecimentos que os consumidores geralmente compram produtos orgânicos.

O CEASA representa 23,56\% do lugar de compra de produtos orgânicos. O que é considerado um baixo índice, levando em consideração que é a maior concentração de produtores de orgânicos do Distrito Federal. É possível perceber que esse fator pode estar relacionado a distância entre as principais rotas dos consumidores, aos dias e horários restritos, as formas de pagamento. Versiani (2016) observou a CEASA como lugar que vende produtos de qualidade, frescos, com bastante diversidade e com bons preços.

A possibilidade de fazer suas compras perto do trabalho é uma boa opção, porém a aceitação passa a ser limitada em virtude de aspectos como o horário de funcionamento da feira que geralmente limita o horário de entrada do consumidor em seu ambiente de trabalho, ou almoço. Além, de limitar a compra de produtos perecíveis como hortaliças e frutas que exigem um ambiente ideal de acondicionamento. Com uma pequena representatividade, sendo 8,17\% 
as feiras nas proximidades do ambiente de trabalho não é o lugar que o consumidor costuma comprar.

Os restaurantes de produtos orgânicos passaram a ser uma opção para os consumidores com menos tempo, ou que buscam maior comodidade. Representam 9,34\% do lugar de compra de produto orgânicos no Distrito Federal.

A menor representação de produtos orgânicos está na compra pela Internet, com apenas $2,88 \%$. Pode-se justificar por duas possibilidades a falta de credibilidade ou um nicho ainda pouco explorado.

Esta pergunta ofereceu a possibilidade de escolha de mais de uma variável, sendo assim, para complementar a análise desenvolveu-se uma matriz de correlação para compreender como estes estabelecimentos estão associados. Ou seja, quando maior o coeficiente de Pearson, maior é a chance do consumidor comprar nos dois tipos de estabelecimentos (Tabela 04).

Tabela 4 -Locais de compra de produtos orgânicos do Distrito Federal.

\begin{tabular}{|c|c|c|c|c|c|c|c|c|}
\hline Matriz de correlação* & Feira - Casa & CEASA & Empórios & Hipermercados & Internet & Restaurantes & Supermercados & Feira Trabalho \\
\hline Feira de produtos orgânicos - Proximidade de Casa & 1,0000 & $-0,0168$ & $-0,0357$ & 0,2456 & $-0,0313$ & 0,1676 & 0,2909 & 0,1134 \\
\hline Feira - CEASA & 0,0168 & 1,0000 & 0,0786 & 0,1389 & 0,1074 & 0,0599 & 0,0979 & 0,0825 \\
\hline Empórios/Lojas especializadas & 0,0357 & 0,0786 & 1,0000 & 0,0781 & 0,1688 & 0,2460 & 0,0096 & 0,0069 \\
\hline Hipermercado & 0,2456 & $-0,1389$ & 0,0781 & 1,0000 & $-0,0711$ & 0,0367 & 0,1446 & 0,0806 \\
\hline Internet (Sites de produtos orgânicos) & 0,0313 & 0,1074 & 0,1688 & 0,0711 & 1,0000 & 0,1448 & 0,1431 & 0,0514 \\
\hline Restaurante de produtos orgânicos & 0,1676 & 0,0599 & 0,2460 & 0,0367 & 0,1448 & 1,0000 & 0,0351 & 0,0337 \\
\hline Supermercado & 0,2909 & $-0,0979$ & $-0,0096$ & 0,1446 & $-0,1431$ & 0,0351 & 1,0000 & 0,0642 \\
\hline Feira de produtos orgânicos - Proximidade do trabalho & 0,1134 & 0,0825 & $-0,0069$ & 0,0806 & $-0,0514$ & 0,0337 & 0,0642 & 1,0000 \\
\hline
\end{tabular}

Fonte: Elaborado pelo autor.

Os coeficientes em destaque aparecem como os maiores índices de correlação, ou seja, são fatores que demonstram uma maior chance do consumidor comprar em dois tipos de estabelecimento. Sendo assim, é possível observar que consumidores que optaram por estabelecimentos como feiras próximas de casa também optaram por restaurante de produtos orgânicos. Aqueles que buscam a Ceasa também estão dispostos a irem as lojas especializadas, restaurantes de produtos orgânicos e feiras nas proximidades do trabalho. Os consumidores que optam por irem ao empório também estão dispostos a comprarem seus produtos na CEASA e em hipermercados. Os consumidores que geralmente vão aos hipermercados também compram em supermercado e lojas especializadas. Os consumidores que optam por comprar produtos pela internet também estão dispostos a irem ao CEASA, lojas especializadas, e restaurantes de produtos orgânicos. Consumidores de produtos orgânicos que vão a supermercado se dispõe a comprar também em feiras de produtos orgânicos na proximidade de casa, CEASA, lojas especializadas, e pela internet. 
Dentro desses estabelecimentos os respondentes foram questionários se em algum desses ambientes que eles geralmente frequentam para comprar produtos orgânicos já fizeram algum tipo de reclamação. É possível observar que parte considerável desses clientes nunca realizaram nenhum tipo de reclamação, isso não demonstra que todos os clientes apresentam alto nível de satisfação, apenas que não se queixaram em nenhum momento.

A grande maioria dos respondentes não apresentou nenhum tipo de reclamação. Os clientes que apresentaram algum tipo de reclamação foram direcionados para explicar como se procedeu a reclamação feita, nesta pergunta os respondentes poderiam optar por mais de uma opção.

Os respondentes que apresentaram alguma reclamação (15,9\%) demonstraram insatisfação junto a um representante da loja no momento da insatisfação, sendo este funcionário ou gerente, o equivalente a $75,8 \%$ da atitude do consumidor no momento da reclamação. Em seguida é possível observar que 39\% optou em deixar de comprar naquela loja. O correspondente a 21,2\% influenciou amigos e familiares a fazerem o mesmo, deixarem de comprar naquele estabelecimento. Pouquíssimos moveram uma reclamação formal ou acionaram o meio judicial com intuito de formalizar a reclamação, apenas $3 \%$ agiu desta maneira.

Ao saber que os entrevistados já fizeram reclamações e o contexto destas reclamações, faz-se necessário questionar qual o tipo de reclamação. Nesta pergunta o entrevistado aponta se a reclamação está relacionada a qualidade do produto, ao preço cobrado, a relação de confiança quanto a origem do produto, ao ambiente de vendas, a relação com a cortesia/empatia dos funcionários, conforme descrito na Tabela 5.

Tabela 5- Reclamações dos consumidores de orgânico.

\begin{tabular}{|c|c|c|}
\hline Qual foi o tipo de reclamação? & $\mathrm{N}$ & \\
\hline Relacionada à qualidade do produto & 23 & $69,7 \%$ \\
\hline Relacionada ao preço & 13 & $39,4 \%$ \\
\hline Relacionada à origem do produto (confiança) & 10 & $30,3 \%$ \\
\hline Relacionada ao ambiente de venda dos produtos (estética) & 10 & $30,3 \%$ \\
\hline Relacionada aos funcionários (cortesia/empatia) & 4 & $12,1 \%$ \\
\hline Outros & 3 & $9,1 \%$ \\
\hline
\end{tabular}

Fonte: Elaborado pelo autor.

É possível observar que a grande maioria das reclamações estão relacionadas a qualidade do produto oferecido $69,7 \%$ dos respondentes apontaram este fator como o principal tipo de reclamação.

Logo em seguida é possível perceber um alto índice de reclamações relacionadas ao preço praticado, $39,4 \%$ da amostra diz ter reclamado dos preços praticados. Outro fator que 
gera reclamações está correlacionado a relação de confiança quanto a origem do produto, 30,3\% dos entrevistados já fizeram algum tipo de reclamação relacionada a esta variável. Com mesmo índice $(30,3 \%)$ estão as reclamações relacionadas ao ambiente de venda, as condições estéticas do lugar de comercialização.

A cortesia e empatia dos funcionários no momento de compra é um indicador de reclamação dos consumidores de produtos orgânicos, representa $12,1 \%$ das reclamações. Outros fatores como formas de pagamento, falta de produtos e falta de informação são fatores que juntos representam $9,1 \%$ de todos os respondentes.

Diante das características do mercado de produtos orgânicos faz-se necessário saber se os entrevistados têm interesse em participar de uma cooperativa de produtos orgânicos no Distrito Federal. De todos os entrevistados $60,1 \%$ disseram ter interesse em uma cooperativa de consumidores de produtos orgânicos, enquanto 39,4\% disseram não ter interesse. A cooperativa passa a ser uma alternativa para minimizar os efeitos dos altos custos, levando em consideração que possibilita uma redução nos custos e uma melhor estruturação, conforme SEBRAE (2010).

A partir do interesse de alguns consumidores de participarem de uma cooperativa de consumidores de produtos orgânicos, perguntou-se quais as vantagens de uma cooperativa de compras de produtos orgânicos você tem maior interesse? Os entrevistados poderiam escolher mais de uma variável e também descrever na opção "outros" fatores diferentes do que os disponíveis, conforme descrito na Tabela 6.

Tabela 6- Vantagens da cooperativa de consumidores de orgânico.

Quais das vantagens de uma cooperativa de compras de produtos orgânicos você tem maior interesse?

\begin{tabular}{lrr} 
& $\mathbf{N}$ & $\%$ \\
\hline Desconto - Preço & 108 & $86,4 \%$ \\
Garantia de origem do produto & 106 & $84,8 \%$ \\
Variedade de produtos & 82 & $65,6 \%$ \\
Preocupação Ambiental & 73 & $58,4 \%$ \\
Comodidade & 61 & $48,8 \%$ \\
Preocupação Social & 53 & $42,4 \%$ \\
Acesso a produtos exclusivos & 47 & $37,6 \%$ \\
\hline
\end{tabular}

Fonte: Elaborado pelo autor.

O maior interesse em participar de uma cooperativa de consumidores de produtos orgânicos está relacionado a uma vantagem monetária e a garantia de origem do produto. Desconto relacionado ao preço é a maior vantagem apontada pelos entrevistados, e representa $86,4 \%$. Garantia de origem do produto tem $84,8 \%$ representa outra vantagem relacionada a participação em uma cooperativa de orgânicos. A variedade dos produtos orgânicos disponíveis 
é um ponto de $65,6 \%$ que desperta interesse dos consumidores. A cooperativa demonstrar interesse com questões ambientais representa 58,4\% das vantagens. Comodidade representa $48,8 \%$ das possíveis vantagens que os entrevistados despertaram maior interesse. A preocupação social é outra vantagem apontada para $42,4 \%$ dos entrevistados. Acesso a produtos exclusivos representa $37,6 \%$ dos interesses dos entrevistados.

\subsection{Análise competitiva dos canais de comercialização de produtos orgânicos no Distrito Federal}

A segunda parte da pesquisa busca demonstrar o atual cenário de comercialização de produtos orgânicos no Distrito Federal. Esta pesquisa tem como objetivo principal analisar a competitividade dos canais de comercialização de produtos orgânicos no Distrito Federal. Definiu-se o perfil demográfico, os principais hábitos de consumo de produtos orgânicos,

A amostra foi dividida em consumidores e não consumidores de produtos orgânicos, ao total de 314 respondentes, $61 \%$ se manifestaram dizendo que consomem produtos orgânicos, e 38,2\% não consomem produtos orgânicos. O número de consumidores de produtos orgânicos passou a ser maior.

Após a classificação dos entrevistados passa-se a analisar o perfil sociodemográfico desta amostra.

\subsubsection{Dados Demográficos}

\subsubsection{Gênero}

Em análise ao perfil demográfico apresentado na pesquisa é possível observar que a amostra dividida por gênero e entre consumidores e não consumidores de produtos orgânicos se organiza da seguinte forma: aqueles que consomem produtos orgânicos são em sua maioria do gênero feminino e representam 63,4\% dos consumidores de produtos orgânicos, enquanto o público masculino representa 36,6\% dos consumidores de orgânicos. Em uma análise comparativa em dois anos 2004 e 2008 é possível perceber um cenário muito similar ao apresentando nesta pesquisa, ou seja, Almeida e Junqueira (2012) reafirmam que a compra de produtos orgânicos é predominantemente feito pelo gênero feminino, em 2004, (34\%) pertenciam ao gênero masculino, enquanto $(65,3 \%)$ ao gênero masculino; em 2008, $(27,7 \%)$ pertencia ao gênero masculino enquanto $(62,7 \%)$ ao gênero feminino. E, complementam afirmando que o gênero feminino é quem detém o poder de decisão em questões importantes 
relacionadas a alimentação e saúde (ALMEIDA, JUNQUEIRA; 2012 apud KOTLER, KARTAJAYA e SETIAWAN, 2010)

A análise feita por gênero, porém sobre aqueles que não consomem produtos orgânicos observa-se a seguinte divisão: $62,5 \%$ são do gênero feminino, enquanto 37,5\% gênero masculino.

Dentro de uma mesma categoria é possível observar que $62,1 \%$ do gênero feminino consome produtos orgânicos enquanto 37,9\% não consome. No gênero masculino os índices são $61,2 \%$ de consumidores e $38,8 \%$ de não consumidores de produtos orgânicos.

\subsubsection{Estado Civil}

Ao se questionar sobre o estado civil e a presença de filhos observou-se que os consumidores de produtos orgânicos são divididos em: $52,6 \%$ casados e $47,4 \%$ de solteiros, onde $47,4 \%$ não possui filho e $52,6 \%$ possuem filho.

Os entrevistados que não consomem produtos orgânicos 36,7\% deles são casados, $63,3 \%$ são solteiros, e 67,5\% não possui filhos enquanto $31,7 \%$ possuem filhos e não consomem produtos orgânicos.

Quando a amostra é dividida por categoria é possível observar que entre os casados 69,9\% da amostra consomem produtos orgânicos enquanto 30,1\% não consomem. Já entre os solteiros 54,8\% consomem produtos orgânicos e 45,2\% não consome.

Daqueles que não possuem filhos 53,2\% consomem produtos orgânicos enquanto 46,8\% não consome. As famílias que possuem filhos demonstraram que 72,9\% consomem produtos orgânicos enquanto $27,1 \%$ não consomem.

\subsubsection{Grau de Escolaridade}

Ao se analisar o grau de escolaridade dos respondentes é possível observar que em sua grande maioria possuem nível superior. A amostra de consumidores de produtos orgânicos ficou dividida da seguinte forma: $0,5 \%$ com ensino fundamental, 13,9\% com ensino médio, 47,4\% com ensino superior, 38,1\% com pós-graduação. Cenário similar ao apresentado, na pesquisa "Evolução do perfil do consumidor de hortaliças orgânicas em Brasília- DF", que apresenta dados dos anos de 2004, 2008 e 2011. Em 2004, (44\%) da amostra apresentava pelo menos ensino superior e (8,7\%) pós-graduação, em 2008, (76\%) apresentavam ensino superior e $(26,8 \%)$ pós-graduação, e em $2011,(71,8 \%)$ possuíam ensino superior e $(25,2 \%)$ pósgraduação (ALMEIDA; JUNQUEIRA; 2012). 
Aqueles que não consomem produtos orgânicos tem como grau de escolaridade: $15 \%$ ensino médio, $61,7 \%$ possuem ensino superior, $23,3 \%$ com pós-graduação.

Quando se analisa o extrato por escolaridade, é possível observar que todos aqueles que estão no ensino fundamental consomem produtos orgânicos, no ensino médio $60 \%$ consome $40 \%$ não consome, no ensino superior $55,4 \%$ consomem enquanto $44,6 \%$ não consome, com grau de especialista $72,5 \%$ consomem enquanto $27,5 \%$ não consomem.

\subsubsection{Faixa Etária}

Em uma análise de faixa etária percebe-se uma concentração de entrevistados nas idades entre 26-45 anos. Aqueles que consomem produtos orgânicos e são menores de 18 anos representam 1,5\% da amostra. Os jovens de 18-25 anos são responsáveis por 21,1\%. De 46-65 anos 22,2\% se dizem consumidores. Mais de 65 anos representa 3,6\% dos consumidores. A maior concentração de consumidores de produtos orgânicos está presente na faixa etária entre 46-65 anos, o que corrobora com os dados apresentados pelos consumidores de hortaliças orgânicos do DF, onde a concentração de consumidores tem faixa etária de 31 a 50 anos de idade, os autores Almeida e Junqueira (2012) fazem uma correlação da idade e o surgimento de doenças relacionadas a hábitos alimentares, como: diabetes, colesterol alto e hipertensão, e a preocupação com o envelhecimento saudável e qualidade de vida.

As idades daqueles que não consomem produtos orgânicos é dividida da seguinte forma: Nenhum dos entrevistados com menos de 18 anos disseram que não consomem produtos orgânicos. Os que possuem idade de 18-25 anos representam 47,5\% dos que não consomem produtos orgânicos. De 26-45 anos 45\% não são consumidores de produtos orgânicos. Entre 46-65 anos 7,5\% apontam não consumir produtos orgânicos. Nenhum entrevistado com mais de 65 anos se manifestou relatando que não consome produtos orgânicos.

Em uma avaliação que leva em consideração a idade e o consumo ou não consumo de produtos orgânicos é possível observar que: 100\% dos entrevistados com menos de 18 anos são consumidores de produtos orgânicos, entre 18-25 anos 41,8\% consomem enquanto 58,2\% não consomem, de 26-45 anos 64,9\% consomem e 35,1\% não consomem, 46-65 anos 82,7\% consomem e 17,3\% não consomem, com mais de 65 anos $100 \%$ da amostra consome.

\subsubsection{Renda}

A última característica demográfica analisada foi renda. Onde é possível perceber o poder aquisitivo dos entrevistados e segmenta-los em consumidores e não consumidores de 
produtos orgânicos. Para os consumidores de produtos orgânicos a distribuição de renda tem a seguinte característica: $16 \%$ possuem renda menor que $\mathrm{R} \$ 2.000,00$; com renda entre $\mathrm{R} \$$ $\mathrm{R} \$ 2.001-\mathrm{R} \$ 4.000$ o equivalente a $19,1 \%$; entre $\mathrm{R} \$ 4.001-\mathrm{R} \$ 6.000$ são 10,3\%, com renda entre $\mathrm{R}$ \$ 6.001-R \$10.000 são 19,1\%, acima de $\mathrm{R} \$ 10.000$ são 17,5\%, aqueles que preferiram não responder são 18\%. As pesquisas realizadas nos anos de 2004. 2008 e 2011 demonstraram que as hortaliças orgânicas são adquiridas por consumidores com alto poder aquisitivo e com alto nível de instrução (ALMEIDA, JUNQUEIRA; 2012).

Aqueles que não dizem não consumir produtos orgânicos são distribuídos da seguinte forma: $41,7 \%$ possuem renda menor que $\mathrm{R} \$ 2.000,00$; com renda entre 2.001-4.000 o equivalente a 25,8\%; entre $\mathrm{R} \$ 4.001-6.000$ são 5,8\%, com renda entre $\mathrm{R} \$$ 6.001-10.000 são 14,2\%, acima de $\mathrm{R} \$ 10.000$ são 5,00\%, aqueles que preferiram não responder são 7,5\%.

A distribuição feita por renda entre consumidores e não consumidores de produtos orgânicos quanto a renda foi feita da seguinte forma: com menos de $\mathrm{R} \$ 2.000$ equivale a 38,3\% de consumidores e $61,7 \%$ de não consumidores de produtos orgânicos, com renda ente $\mathrm{R} \$ 2.001$ - 4.000 se mostraram consumidores $54,4 \%$, e não consumidores $45,6 \%$, entre $\mathrm{R} \$ 4.001$ 6000 são 74,1\% de consumidores e 25,9\% de não consumidores, entre R \$ 6.001-10.000 são consumidores $68,5 \%$, e $31,5 \%$ não são consumidores, acima de $\mathrm{R} \$ 10.000 \quad 85 \%$ são consumidores e $15 \%$ não são consumidores. Daqueles que preferiram não responder 79,5\% são consumidores e $20,5 \%$ não são consumidores.

Após a análise sócio demográfica as análises foram direcionadas para os motivos que levam um consumidor a consumir ou não um produto orgânico, a frequência de consumo, a média de gasto mensal e o tipo de produto mais consumido.

\subsubsection{Motivos para não consumir produtos orgânicos}

Os entrevistados foram questionados a respeito do principal motivo para não consumirem produtos orgânicos, foram disponibilizadas as seguintes variáveis: preço alto, a percepção de qualidade, não perceber diferença entre os produtos orgânicos e o convencional, e o não conhecimento do que seria produtos orgânicos.

Quanto aos principais motivos que fazem os entrevistados a não consumirem a grande maioria permanece apontando como o preço sendo este o principal motivo para não consumirem produtos orgânicos. Alguns produtos são considerados produtos do mercado de luxo, classificados como premium, e geralmente são mais caros de 100 a $300 \%$ quando comparados com produtos convencionais (IPD, 2011). 
A segunda maior parcela dos entrevistados apontaram o desconhecimento do produto orgânico como maior fator que não motiva seu consumo, sendo responsáveis por $20,8 \%$ de toda a amostra. O desconhecimento limita o consumo e faz com que as pessoas não percebam diferença entre o produto convencional e o produto orgânico. A falta de informação interfere diretamente em parte da amostra que aponta não perceber diferença entre produtos convencionais e orgânicos, 7,5\%. Parte da amostra aponta que não percebe qualidade ao consumirem produtos orgânicos, representa 5,8\%. Oliveira e Marjotta-Maistro (2016) afirmam que as maiores dificuldades enfrentadas na comercialização de produtos orgânicos são o desconhecimento da qualidade do produto e o senso comum que afirma que o preço do orgânico é maior que o convencional, afastando assim possíveis consumidores.

Cenário similar ao encontrado por Sylvander (1998) em um estudo em quatro países, (Itália, Inglaterra, França e Alemanha), onde os três motivos que limitam o consumo de produtos orgânicos está relacionado aos altos preços, oferta insuficiente e a dúvida em relação a origem do produto (IPARDES; 2007 aput Sylvander; 1998).

\subsubsection{Principais motivos dos consumidores de produtos orgânicos}

Aos consumidores de produtos orgânicos fez-se as mesmas perguntas, qual o principal motivo de você consumir produtos orgânicos? As variáveis disponíveis para resposta eram preocupação com saúde, influência de família e amigos, por ser mais saboroso, preservação do meio ambiente e por ajudar o pequeno produtor, conforme descritos na Tabela 7.

Tabela 7- Motivos de consumo de orgânicos.

\begin{tabular}{lcc}
\hline Qual o principal motivos de você consumir produtos orgânicos? & $\mathrm{N}$ & $\%$ \\
\hline Preocupação com a saúde & 153 & $79,3 \%$ \\
Influência família/amigos & 15 & $7,8 \%$ \\
Por ser mais saboroso & 10 & $5,2 \%$ \\
Preservação do meio ambiente & 9 & $4,7 \%$ \\
Por ajudar o pequeno agricultor & 6 & $3,1 \%$ \\
\hline
\end{tabular}

Fonte: Elaborado pelo autor.

O principal fator motivador para o consumo de produtos orgânicos continua sendo a preocupação com a saúde, $79.3 \%$ de todos os respondentes apontam a saúde como principal fator motivador para o consumo de produtos orgânicos. Ao questionar os consumidores sobre o que os motivou a comprar produtos orgânicos e não outros - os convencionais - a maioria referiu como item de maior importância a saúde pessoal e familiar (CERVEIRA E CASTRO, 1999). Alguns benefícios relacionados a saúde favorecem as vendas de produtos orgânicos, 
como por exemplo o chá verde, considerado produto auxiliar na perda de peso e os sucos que promovem um melhor funcionamento do sistema imune e apresentam propriedades antienvelhecimento (IPD,2011).

A família e amigos exercem o segundo maior fator de influência dos consumidores a consumirem produtos orgânicos. Família e amigos formam o primeiro grupo de referência para consumo, criam hábitos e costumes que são formadores da personalidade. Cerveira e Castro (1999) afirmam que eu sua pesquisa o maior veículo de informação e influência de consumidores de produtos orgânicos é a propaganda feita por familiares e amigos.

O paladar é um fator que influencia muitas pessoas em seus hábitos de compra. Os respondentes que apontaram como produto mais saboroso, 5,2\% são fortes influenciados pelo sabor.

A preocupação com o meio ambiente representa parte da amostra que evidencia este como o principal motivador para o consumo de orgânicos (FONSECA, 2005). Nesta amostra representa 4,7\% dos respondentes. Trevizan e Casemiro (2009) afirmam que a vinculação com instituições ou movimentos ambientalistas não são determinantes na compra de produtos orgânicos, demonstraram que $(77 \%)$ da amostra dos consumidores de produtos orgânicos não possuem nenhuma relação com causa ambiental.

Ser solidário, e estar preocupado com a condição social é outro fator importante para os consumidores no momento de compra. A ajuda prestada ao pequeno agricultor é um fator motivador para a compra de produtos orgânicos. De todos os respondentes 3,1\% são motivados pela ajuda prestada ao pequeno agricultor.

\subsubsection{Frequência de Consumo}

Ao serem perguntados sobre qual a frequência de compra de produtos orgânicos as variáveis de frequência disponíveis eram: diariamente, semanalmente, quinzenalmente e mensalmente. A distribuição de entrevistados demonstra a seguinte perspectiva: semanalmente 56,5\%; mensalmente 19,7\%, 14\% quinzenalmente, 9,8\% diariamente. É importante destacar que a frequência semanal tem como fator de influência a perecibilidade dos produtos orgânicos, como frutas, legumes e verduras, além, da disponibilidade de feiras nas proximidades de casa que geralmente acontecem uma vez na semana. Cerveira e Castro (1999) ao pesquisarem sobre os consumidores de produtos orgânicos da cidade de São Paulo, reafirmam os dados onde mais de $80 \%$ fazem compras de produtos orgânico, na feira semanalmente, isto é, mantém a regularidade de suas compras. Para Vilela et al (2006) aqueles que possuem maior renda são 
aqueles que consomem em maior quantidade e adquirem com maior frequência, seja diária ou semanal, (79\%) da amostra de consumidores de também compram semanalmente, enquanto 13\% dos entrevistados compra duas vezes por semana. Versiani (2016) reafirma a preferência do seu consumidor (61\%) está em comprar semanalmente na CEASA-DF.

Além da frequência de consumo é importante saber o ticket médio deste consumidor. Foi feita a seguinte pergunta: qual o seu gasto mensal com produtos orgânicos. A escala de resposta pré-definida tem como variáveis: menos de $R$ \$ 100, entre $R \$ 101-200, R \$ 201-300$, $\mathrm{R} \$ 301-400, \mathrm{R} \$ 401-500$, e mais de $\mathrm{R} \$ 500$.

Os respondentes apontam que geralmente gastam manos de $\mathrm{R} \$ 100$ por mês com produtos orgânicos. Foram 39,9\% dos entrevistados que apontaram que gastam menos de R\$ 100. As variáveis segundo o gasto mensal foram distribuídas da seguinte forma: $28 \%$ gastam entre $\mathrm{R} \$ 101-200,19,7 \%$ gastam entre $\mathrm{R} \$ 201-300,6,2 \%$ gastam entre $\mathrm{R} \$ 301-400,2,1 \%$ gastam entre $\mathrm{R} \$ 401-500,4,1 \%$ gastam mais de $\mathrm{R} \$ 500$.

É importante destacar aspectos relacionados ao consumo de produtos orgânicos, qual o produto orgânico que o entrevistado mais consome. Dentre eles foram elencados: hortaliças, frutas, legumes, carnes, café e leite.

O produto orgânico com maior demanda é a categoria hortaliças, representa $(59,6 \%)$ de todos os produtos mais consumidos. Assim o apontado por Versiani (2016), em que (53\%) de sua amostra optaram por folhas e verduras, com preferência para: rúcula, alface, couve e brócolis. Logo em seguida vem as frutas com 23,3\%. Legumes apresenta uma demanda de $11,4 \%$, carne branca com $3,1 \%$, carne vermelha com $2,1 \%$ e café e leite com $0,5 \%$ cada um.

\subsubsection{Local de compra de produtos orgânicos}

É interessante mapear o lugar de compra dos consumidores de orgânicos, para isso o questionário faz a seguinte pergunta: qual o principal local você costuma comprar produtos orgânicos? E elenca-se as seguintes variáveis para escolha: feiras, hipermercados/supermercados, CSA e internet.

Os respondentes afirmam que o principal local de compra de produtos orgânicos são as Feiras. Com 53,9\% a feira tem a maior representatividade diante dos locais de compra. As feiras exigem geralmente um investimento inicial, diante de um baixo volume e diversidade e produção e as grandes distâncias entre a propriedade e a feira (SEBRAE;2010). A feira livre, segundo Oliveira e Marjotta-Maistro (2016), em seu trabalho Canais de comercialização de orgânicos: alternativas para os agricultores familiares do Leste Paulista, é o melhor lugar para 
o produtor rural comercializar seus produtos, em virtude do melhor preço e da fidelização dos consumidores, onde o contato direto com o consumidor facilita a organização da produção e garante aspectos de qualidade frente a elogios, críticas e sugestões do próprio consumidor.

Os hipermercados e supermercados concentram $35,2 \%$ de toda a demanda. Oliveira e Marjotta-Maistro (2016) afirmam que os hábitos de compra, exigem cada vez mais características como: diversidade de produtos, rapidez no atendimento, comodidade, entrega a domicílio, ambiente agradável, amplo estacionamento, direcionam os consumidores aos grandes hipermercados ou supermercados. Porém, esses canais de comercialização exigem do produtor rural padronização da entrega, regularidade de abastecimento, cumprimento das datas de entrega e quantidades contratadas, fatores que não irão privilegiar os pequenos produtores a não se estiverem organizados por meio de associações ou cooperativas (SEBRAE;2010). Oliveira e Marjotta-Maistro (2016) complementam a crítica evidenciando como o canal que menos remunera ao produtor rural, fazem a devolução de mercadorias vendidas sem nenhum repasse financeiro, possuem exigências como padrões de embalagens custeados pelo produtor.

Empórios e lojas especializadas representam 4,7\% dos principais locais de compra, Oliveira e Marjotta-Maistro (2016) afirmam que ao contrário dos hipermercados e supermercados, que geralmente exigem grandes volumes e pagam menos ao produtor, as lojas especializadas oferecem vantagens como a compra de pequenos produtores ou associações de produtores com uma melhor remuneração. As CSAs representam 4,1\% de toda a amostra, e torna-se interessante por ter uma relação que aproxima o produtor ao consumidor, minimiza as chances de erro de produção, com excessos ou faltas, tornando a produção mais precisa, sem grandes desperdícios, como afirmam Oliveira e Marjotta-Maistro (2016). E a internet representa apenas 2,6\% dos locais de compra favoritos dos consumidores de produtos orgânicos.

\subsubsection{Fatores ambientais que influenciam a compra de produtos orgânicos}

Elencou-se os fatores mais importantes no momento de compra de produtos orgânicos com intuito de determinar quais fatores de um ambiente de compra podem gerar competitividade.

Em uma escala de Likert classificou-se por uma média ponderada os fatores em sem importância, pouco importante, indiferente, importante e muito importante. Os fatores relacionados são: limpeza e higienização do ambiente de compra, origem do produto, aparência do produto, qualidade do atendimento, sensação de segurança no momento da compra variedade de produtos, disponibilidade de produtos, descontos e promoções, economia no momento da compra, proximidade de casa, formas de pagamento, horário de funcionamento, temperatura do 
ambiente de compra, disposição do produto na área de venda, estacionamento, atendimento pós-venda, aparência dos funcionários, número de caixas, divulgação dos produtos, proximidade com o trabalho, oferta de itens complementares, disponibilidade de marca preferida, conhecer o dono do estabelecimento, conhecer os funcionários, descritos na Tabela 8.

Tabela 8 - Fatores importantes ao realizar a compra de orgânicos.

\begin{tabular}{|c|c|c|c|c|c|c|}
\hline Quais fatores são importantes ao realizar a compra de produtos orgânicos & $\begin{array}{c}\text { Sem } \\
\text { importância }\end{array}$ & $\begin{array}{c}\text { Pouco } \\
\text { importante }\end{array}$ & Indiferente & Importante & $\begin{array}{c}\text { Muito } \\
\text { importante }\end{array}$ & $\begin{array}{c}\text { Nota } \\
\text { Ponderada }\end{array}$ \\
\hline Limpeza/higienização do ambiente de compra & 0 & 2 & 6 & 42 & 141 & 4,69 \\
\hline Origem do produto & 0 & 1 & 10 & 65 & 116 & 4,54 \\
\hline Aparência do produto & 1 & 3 & 11 & 59 & 115 & 4,50 \\
\hline Qualidade do atendimento & 0 & 3 & 15 & 66 & 102 & 4,44 \\
\hline Sensação de segurança no momento da compra & 2 & 2 & 20 & 69 & 93 & 4,34 \\
\hline Variedade dos produtos & 2 & 5 & 8 & 86 & 87 & 4,34 \\
\hline Disponibilidade do produto & 0 & 6 & 14 & 88 & 75 & 4,27 \\
\hline Descontos e promoções & 2 & 4 & 24 & 72 & 82 & 4,24 \\
\hline Economia na compra & 2 & 6 & 24 & 71 & 84 & 4,22 \\
\hline Proximidade de casa & 2 & 5 & 28 & 83 & 72 & 4,15 \\
\hline Formas de pagamento (cartão de débito, crédito, alimentação, refeição, dinheiro,cheque) & 5 & 6 & 29 & 63 & 81 & 4,14 \\
\hline Horário de funcionamento & 4 & 7 & 26 & 85 & 64 & 4,06 \\
\hline Temperatura do ambiente de compra & 6 & 10 & 24 & 88 & 55 & 3,96 \\
\hline Disposição do produto na área de compra (gôndola, freezer, geladeira, proximidade com caixa) & 9 & 8 & 31 & 70 & 66 & 3,96 \\
\hline Estacionamento & 12 & 6 & 33 & 69 & 63 & 3,90 \\
\hline Atendimento pós venda (reclamações, sugestões) & 6 & 10 & 42 & 75 & 51 & 3,84 \\
\hline Aparência dos funcionários & 8 & 11 & 41 & 81 & 40 & 3,74 \\
\hline Número de caixas & 15 & 13 & 44 & 66 & 44 & 3,61 \\
\hline Divulgação do produto (encartes, banners, cartazes) & 10 & 13 & 51 & 73 & 35 & 3,60 \\
\hline Proximidade do trabalho & 14 & 14 & 51 & 61 & 45 & 3,59 \\
\hline Oferta de itens complementares (lanchonete, praça de alimentação, farmácias, lojas) & 21 & 19 & 58 & 49 & 35 & 3,32 \\
\hline Disponibilidade da marca preferida & 14 & 19 & 75 & 46 & 28 & 3,30 \\
\hline Conhecer o dono (conhecido, colega, amigo) & 23 & 14 & 64 & 53 & 31 & 3,30 \\
\hline Conhecer os funcionários (conhecido, colega, amigo) & 23 & 12 & 74 & 54 & 21 & 3,21 \\
\hline
\end{tabular}

Fonte: Elaborado pelo autor.

A partir da das variáveis elencadas na pesquisa é possível perceber que o fator mais importante para os consumidores no momento de compra está relacionado a limpeza e higienização do ambiente de compra. Com média igual a $(4,69)$ esse fator influencia a capacidade de ser competitiva de um estabelecimento. Resultado diferente do apresentado em uma pesquisa realizada em Pelotas/RS, quando se analisa números absolutos, onde os pesquisadores consideram apenas os atributos valorizados pelos consumidores na escolha de um supermercado, e o principal fator apresentado é preço, e logo em seguida higiene e atendimento. Porém, na mesma pesquisa, quando se analisa o gênero feminino o resultado é semelhante ao da pesquisa apresentada, as mulheres elegeram o fator higiene como o mais importante em uma compra de alimentos dentro de um supermercado (GALÃO; SOUZA;2015).

Os consumidores apontam como segundo fator mais importante a origem do produto, com $(4,54)$ de média é um fator determinante para o estabelecimento demonstrar que os produtos são de origem confiável. Barbosa et al (2011), afirma em sua pesquisa, realizada em 
Goiânia-GO, para determinar o perfil do consumidor e as oscilações de preço de produtos agroecológicos, que quanto a origem do produto orgânico $32 \%$ dos consumidores recorrem a etiqueta/selo, $31 \%$ afirmaram saber a procedência do produto, $20 \%$ atribuem a confiança no vendedor principalmente em feiras e em grandes supermercados.

A aparência do produto passa a ser item de relevância para a pesquisa com média igual a (4,50). Barbosa et al (2011) em sua pesquisa evidencia que alguns consumidores preferem escolher produtos por sua aparência, sendo um total de 15,1\% daqueles que frequentam supermercados e 16,9\% daqueles que frequentam feiras, sendo o produto orgânico o produto de pior aparência. Ao contrário do que afirma Oliveira e Quevedo (2012), que em sua amostra, independe de outras variáveis os entrevistados foram unanimes em evidenciar que os produtos orgânicos têm melhor aparência do que os produtos convencionais.

$\mathrm{O}$ atendimento no estabelecimento de compra de produtos orgânicos tem média igual a 4,44, é uma variável de forte influência no comportamento de compra de produtos orgânicos. Vê-se as mesmas características no trabalho de Noronha (2008), que avaliou o comportamento do consumidor de produtos orgânicos de Belo Horizonte - MG, sendo este onde o segundo atributo mais mencionado pelos entrevistados como influenciador na compra foi o atendimento $(26,68 \%)$ de sua amostra.

dA sensação de segurança no momento de compra é um fator considerável para o ambiente concorrencial, ambientes que não promovem a segurança comprovem o nível de satisfação do consumidor logo, se tornam menos competitivos. Esta variável tem como média 4,34 .

A variedade de produtos é um fator cuja a importância é relevante pois leva-se em consideração a diversidade de produtos disponíveis para compra. Quanto maior é a variedade de produtos disponíveis maior a possibilidade de compra, sendo assim, mais competitivo será o estabelecimento. A ruptura de produtos ou a falta de produtos torna o ambiente menos competitivo, uma variável que influencia os consumidores a procurarem outro estabelecimento para compra, tornando-o menos competitivo. Um grande varejista começou a diversificar seu portfólio de orgânico com iogurtes orgânicos, azeites de oliva, biscoitos e arroz, e sua marca própria, sua diretoria decidiu ampliar os investimentos em $40 \%$ nas vendas de produtos orgânicos, incluindo alimentos frescos e a granel (IPD,2011). Galão e Souza (2015) reafirmam a importância de se ter grandes variedades de produtos em grandes redes supermercadista, e evidenciam que esse é um fator decisivo na escolha de um supermercado pelo consumidor.

A presença de descontos, promoções, e economia no momento de compra não é fator determinante para manutenção da competitividade de um estabelecimento que venda produtos 
orgânicos. O que não é possível observar na pesquisa de Galão e Souza (2015), que evidencia os três atributos mais importantes para escolha de um supermercado como local de compra, sendo eles preços baixos, ofertas e promoções.

Estar próximo de casa tem média é um fator relevante para a amostra e conta como fator que interfere na decisão do consumidor.

A forma de pagamento $(4,14)$ é uma variável importante para o consumidor, em uma relação proporcional quanto maior forem as formas de pagamento aceitas no estabelecimento maior será a competitividade do estabelecimento.

A flexibilidade do horário de funcionamento do estabelecimento é outro fator importante para o consumidor no momento de compra, é possível perceber que o horário estendido proporciona maior chance de consumidores comprarem o que tona o estabelecimento mais competitivo. Esmeraldo et al (2016) evidencia características que interferem diretamente na competitividade da feira orgânica presente em Brasília-DF, justifica que o horário de atendimento é curto e pode despertar no consumidor a busca por um supermercadista, com horário estendido.

A temperatura do ambiente de compra é um é considerada um fator importante, principalmente quando se leva em consideração a praça Distrito Federal em épocas de grande calor. A média desse item é 3,96, e é uma variável apontada como importante por 88 respondentes.

Com a mesma média $(3,96)$ está a disposição dos produtos na área de compra, sendo este um fator relevante para o consumidor. Este é apontado como um fator importante por 70 respondentes. Resultado semelhante ao apresentado na pesquisa de Silva et al (2005) que evidência barreiras para disseminação do consumo de produtos orgânicos no varejo supermercadista de Londrina-PR, a autora constatou que os consumidores de produtos orgânicos, em sua grande maioria, sabem a localização dos produtos e considera-se um fator importante que interfere diretamente no consumo, motivo induz supermercados a concentrarem em uma só secção.

O estacionamento com média $(3,90)$ é um fator apontado pela maioria dos consumidores como importante, principalmente quando se analisa as condições de estacionamento limitados da região. O desconforto para estacionar gera insatisfação para os consumidores, logo, uma menor competitividade para o estabelecimento. Galão e Souza (2015) apresentam que o fator estacionamento, para aqueles que compram gênero alimentício em supermercado na cidade de Pelotas/RS, não é determinante, justificado pela proximidade dos mercados de bairro e as entregas a domicílio. 
O atendimento pós-venda é uma variável com média 3,84 e se apresenta como fator importante par a 75 respondentes, isso demonstra que os estabelecimentos precisam ser acessíveis para receberem críticas e sugestões de melhoria.

A aparência dos funcionários é outra variável tida como importante pela maioria dos respondentes, 81 pessoas apontaram como fator importante, e 40 muito importante.

A variável número de caixas é considerada um fator importante e está diretamente ligada a qualidade no atendimento, fator que pode gerar longas filas ou pequenas filas, e como reflexo é possível ter ou não um estabelecimento competitivo.

Os fatores menos relevantes para um ambiente competitivo diante das variáveis para o consumidor são a oferta de itens complementares no ambiente de venda, como lanchonete, praça da alimentação, farmácia, lojas, tem corresponde a 53,8\% de sem importância, pouco importante ou indiferente, e se apresenta como importante ou muito importante 46,2\%. A disponibilidade de marcas preferidas não é variável importante para consumidores de produtos orgânicos. Como seu grau de importância é possível observar que 59,3\% não considera sem importância, pouco importante ou indiferente, enquanto apenas 40, 7\% considera importante. Conhecer os donos ou os funcionários também não é uma relação que gera importância para o consumidor no momento da compra. 54\% considera esse fator sem importância pouco importante ou indiferente, e apenas 45 agrega algum grau de importância.

As variáveis foram agrupadas por grupo de local de compra, ou seja, é possível observar por uma média ponderada os principais fatores que os consumidores priorizam no momento de realizar a compra de produtos orgânicos segmentados por estabelecimento de compra. Os consumidores opinaram por grau de importância os fatores que são: sem importância, pouco importantes, indiferente, importante e muito importante. Fez-se uma média ponderada com os fatores para classifica-los em ordem de importância para o consumidor.

\subsubsection{Fatores que influenciam a compra - CSA}

A primeira avaliação foi feita com os consumidores das CSAs, comunidade que suporta agricultura, eles elencaram por grau de importância fatores que interferem sua compra. A classificação dos fatores em grau de importância para os consumidores que pertencem a CSA, foram distribuídos da seguinte forma: Qualidade no Atendimento (4,63); Limpeza e higienização do ambiente de compra (4,63), Economia na compra $(4,50)$, aparência do produto $(4,50)$, origem do produto $(4,50)$, descontos e promoções $(4,38)$, sensação de segurança no momento de compra $(4,38)$, disponibilidade do produto $(4,13)$, variedade de produtos $(4,13)$, 
temperatura do ambiente de compra $(3,88)$, horário de funcionamento $(3,88)$, atendimento pós venda $(3,86)$, disposição do produto na área de compra $(3,63)$, proximidade de casa $(3,63)$, formas de pagamento $(3,63)$, aparência dos funcionários $(3,50)$, conhecer o dono $(3,50)$, conhecer os funcionários $(3,50)$, número de caixas $(3,38)$, proximidade do trabalho $(3,38)$, divulgação do produto $(3,38)$, estacionamento $(3,38)$, oferta de itens complementares $(3,25)$, disponibilidade de marca preferida $(3,00)$.

\subsubsection{Fatores que influenciam a compra - Lojas Especializadas}

Quando a análise é feita sobre empórios e lojas especializadas a ordem passa a ser: origem do produto $(4,67)$, limpeza e higienização do ambiente de compra $(4,63)$, sensação de segurança no momento da compra $(4,43)$, horário de funcionamento $(4,29)$, aparência do produto (4.25), qualidade do atendimento $(4,14)$, variedade dos produtos $(4,13)$, economia na compra $(4,00)$, atendimento pós venda $(4,00)$, estacionamento $(3,83)$, proximidade de casa $(3,75)$, formas de pagamento $(3,75)$, disponibilidade do produto $(3,63)$, proximidade do trabalho $(3,63)$, disposição dos produtos na área de venda $(3,57)$, aparência dos funcionários $(3,57)$, conhecer funcionários $(3,57)$, divulgação do produto $(3,57)$, descontos e promoções $(3,29)$, conhecer o dono $(3,29)$, número de caixas $(3,00)$, disponibilidade da marca preferida $(2,86)$, temperatura do ambiente de compra $(2,71)$, oferta de itens complementares $(2,71)$.

\subsubsection{Fatores que influenciam a compra - Feiras}

Quando a análise é feita em feiras observa-se o seguinte cenário: limpeza e higienização do ambiente de compra $(4,66)$, origem do produto $(4,56)$, qualidade do atendimento $(4,55)$, aparência do produto $(4,44)$, sensação de segurança no momento da compra $(4,32)$, variedade dos produtos $(4,25)$, disponibilidade do produto $(4,19)$, proximidade de casa $(4,17)$, economia na compra $(4,16)$, descontos e promoções $(4,16)$, horário de funcionamento $(4,10)$, formas de pagamento (4,08), temperatura do ambiente de compra $(4,08)$, estacionamento $(4,01)$, disposição do produto na área de compra $(3,95)$, atendimento pós venda $(3,91)$, aparência dos funcionários $(3,83)$, número de caixas $(3,74)$, proximidade do trabalho $(3,61)$, divulgação de produtos $(3,55)$, conhecer o dono $(3,53)$, oferta de itens complementares $(3,36)$, conhecer os funcionários $(3,33)$, disponibilidade da marca preferida $(3,07)$. 


\subsubsection{Fatores que influenciam a compra - Supermercados/Hipermercados}

Quando a análise é feita em hipermercados e supermercados observa-se o seguinte cenário: limpeza e higienização do ambiente de compra $(4,73)$, aparência do produto $(4,65)$, variedade dos produtos $(4,52)$, disponibilidade do produto $(4,49)$, origem do produto $(4,46)$, descontos e promoções $(4,45)$, formas de pagamento $(4,35)$, economia na compra $(4,31)$, sensação de segurança no momento de compra $(4,30)$, qualidade do atendimento $(4,28)$, proximidade de casa $(4,26)$, disposição do produto na área de compra $(4,19)$, temperatura do ambiente de compra $(4,10)$, horário de funcionamento $(4,07)$, estacionamento $(3,85)$, disponibilidade de marca preferida $(3,79)$, divulgação do produto $(3,73)$, atendimento pós venda $(3,72)$, aparência dos funcionários 3,73$)$, proximidade do trabalho $(3,63)$, número de caixas $(3,61)$, oferta de itens complementares $(3,41)$, conhecer os funcionários $(2,94)$, conhecer o dono da loja $(2,93)$.

\subsubsection{Fatores que influenciam a compra - Ambiente Virtual}

Quando a análise é feita diante de um ambiente virtual é possível observar a seguinte ordem de prioridade: origem do produto $(5,0)$, sensação de segurança no momento de compra $(5,0)$, limpeza e higienização do ambiente de compra $(4,80)$, qualidade no atendimento $(4,40)$, economia na compra $(4,20)$, aparência do produto $(4,20)$, variedade dos produtos $(4,20)$, descontos e promoções $(4,00)$, disponibilidade do produto $(4,00)$, atendimento pós venda ( $4,00)$, formas de pagamento $(3,80)$, proximidade de casa $(3,60)$, conhecer o dono $(3,40)$, conhecer os funcionários $(3,40)$, divulgação do produto $(3,40)$, estacionamento $(3,40)$, horário de funcionamento $(3,20)$, aparência dos funcionários $(3,00)$, proximidade do trabalho $(3,00)$, número de caixas $(2,40)$, disponibilidade da marca preferida $(2,40)$, temperatura do ambiente de compra $(2,25)$, oferta de itens complementares $(2,20)$, disposição do produto na área de compra $(2,00)$.

\subsection{Análise do mercado de produtos orgânicos}

Foram ouvidos especialistas do mercado orgânico a respeito da proposta de uma cooperativa de consumidores de produtos orgânicos no Distrito Federal. Nesta análise elencou-se alguns pontos fortes, fracos, ameaças e oportunidades relacionadas ao mercado de produtos orgânicos no Distrito Federal. Abaixo um quadro resumo sobre os principais pontos abordados na entrevista. 
Tabela 9 - Análise do mercado de produtos orgânicos do Distrito Federal.

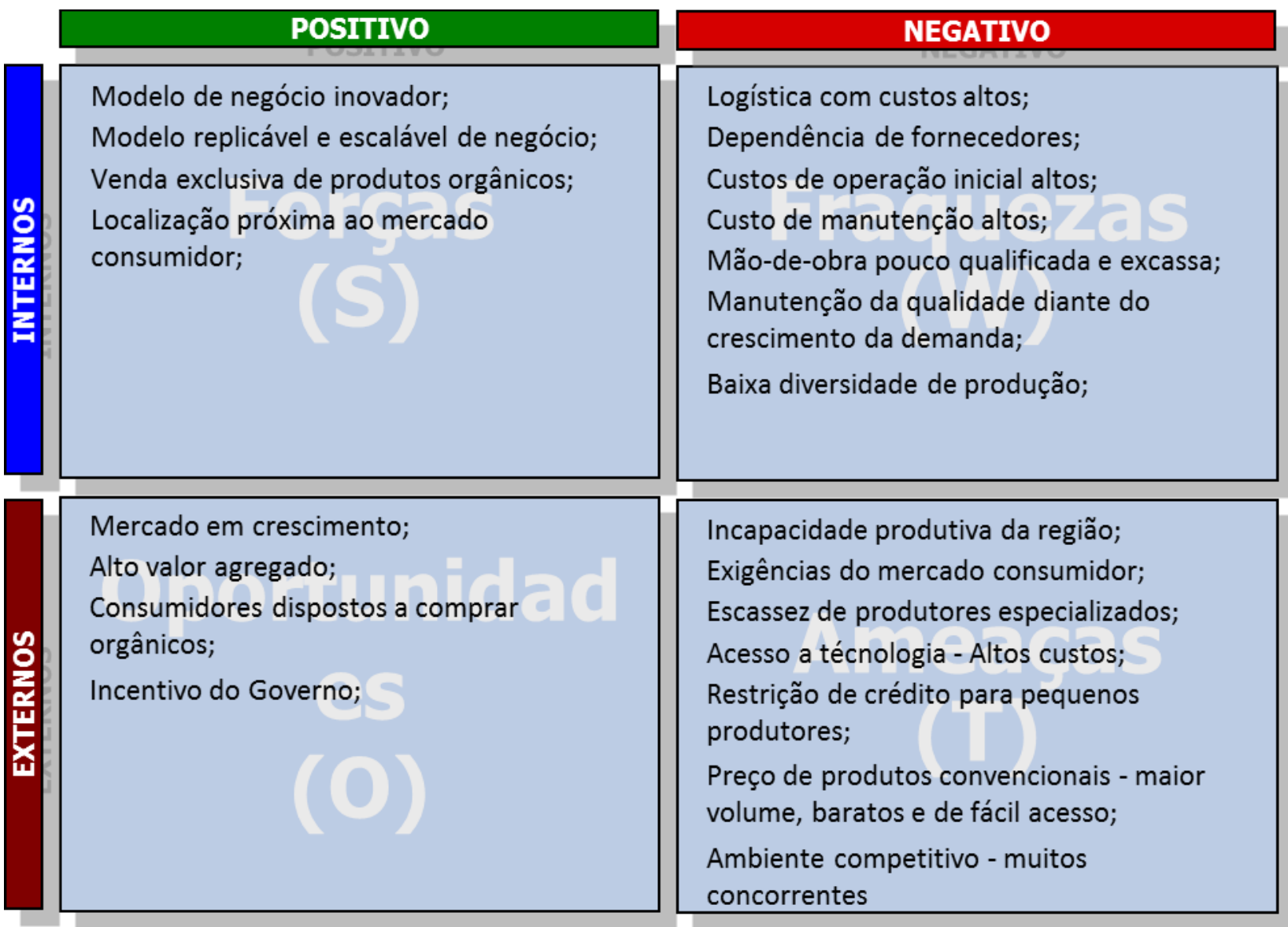

Fonte: elaborado pelo próprio autor.

Na Tabela 9 é possível observar os principais pontos relacionados ao desenvolvimento do mercado de consumidores de produtos orgânicos no Distrito Federal.

Quando questionados sobre avaliação da ideia reagiram de forma positiva, e apontaram que a ideia ter caráter inovador no Distrito Federal. O Entrevistado 01 evidencia que serão necessários alguns ajustes para a viabilidade do mercado de consumidores de produtos orgânicos do Distrito Federal, sendo estes relacionados a aspectos de logística, capacidade produtiva da região, mix de produtos oferecidos, mão de obra qualificada, qualidade do produto ofertado e os custos de toda a operação. Descreve a realidade do mercado local e aponta que existem poucos produtores certificados por OPAC, meio de certificação que garante a revenda de produtos orgânicos, logo, a cooperativa terá que buscar produtores fora da região do Distrito Federal para manter a oferta de seus produtos. A sua sugestão para essa limitação de capacidade produtiva é buscar produtores do estado do Goiás, Minas Gerais e/ou São Paulo, mas essa estratégia tem como consequência o aumento dos custos de todo o processo, indo contra um dos objetivos da cooperativa, e limitando sua capacidade competitiva. Além da incapacidade produtiva do mercado local, tem-se um agravo relacionado a baixa diversidade de produção, 
como a área de fruticultura, por exemplo, que não apresenta capacidade produtiva, e diversidade de produção, para ofertar para o mercado do Distrito Federal, e ressalta que a cooperativa.

A mão de obra qualificada é outro impedimento relacionado ao desenvolvimento da cooperativa de consumidores orgânicos no DF. A mão de obra presente nas produções é escassa, não qualificada e exige do produtor grandes investimentos para capacita-los. Esse aumento de custo é repassado para o mercado consumidor, o que pode tornar inviável a venda de alguns produtos. Além de problemas que ainda acontecem com frequência como: a garantia de entrega no dia e horário acordados, as grandes variações no custo de produção e qualidade do produto oferecido.

A região não possui volume o suficiente para atender o possível aumento de demanda, o que pode acarretar aumento de preços em todo o mercado, a possível perda de qualidade, e ruptura em loja. A obrigação de entrega em grandes volumes pode forçar o produtor a aumentar a frequência de plantio, o que pode comprometer a qualidade do produto orgânico.

Um dos pontos a serem ressaltados é a economia gerada na compra em grandes quantidades, estratégia que auxilia o produtor rural e o consumidor. O produtor rural a partir do poder de barganha junto aos seus fornecedores, reduz assim seus custos de produção, convertidos em descontos ou em uma maior margem. Os consumidores com acesso a produtos de qualidade e a preço acessível, com maior diversidade de produtos, e fácil acesso. Com isso, justifica que o mercado Brasiliense é adapto a novas formas de comercialização, como o modelo sugerido neste trabalho.

Aspectos relacionados a acesso ao mercado consumidor, que está concentrado em feiras, e grandes redes varejistas, que impedem o desenvolvimento dos pequenos produtores de produtos orgânicos ao mercado consumidor, e os tornam pouco competitivos. 


\section{CONCLUSÃO}

Observa-se que a produção de alimentos no modo orgânico é o um setor promissor, que cresce dentro de todo um sistema agrícola com bastante destaque. É possível perceber que as áreas de crescimento englobam tanto o mercado nacional, que está no início do seu desenvolvimento, quanto o mercado internacional. $\mathrm{O}$ grande crescimento do mercado de orgânico se deu de forma determinante pela valorização dos produtos pelo mercado consumidor, em busca de produtos com maior qualidade. A agricultura orgânica no Brasil já se instalou com capacidade de ofertar um sortimento com variedade de produtos de origem animal e vegetal, além de insumos produtivos como pastagens e adubos orgânicos.

As práticas de agricultura orgânica no Brasil são recentes, logo, o material científico relacionado ao tema são ainda insuficientes para uma análise aprofundada, principalmente no que diz respeito à cooperativa de consumidores. Por se tratar de um campo de estudo interdisciplinar, vê-se a possibilidade de contribuição para o desenvolvimento da agricultura no país, em aspectos sociais, econômicos e ecológicos.

Ao se analisar o nível de satisfação dos consumidores e não consumidores de produtos orgânicos no Distrito Federal, aqueles que não consomem produtos orgânicos evidenciam o fator preço como um impeditivo no momento da compra, e um grande causador de insatisfação, por se mostrar inacessível, ser considerado alto, caro. Alguns varejistas se tornaram especialistas na venda de orgânicos, porém, tornam o produto inacessível a grande parte da população em virtude do preço cobrado. As classes C, D e E fazem suas compras baseados no orçamento familiar disponível, não favorecendo o acesso aos produtos orgânicos. Esse fator se complementa a falta de conhecimento de alguns consumidores que não conseguem distinguir entre produtos convencionais e orgânicos, dando preferência ao mais barato, em virtude de seu baixo orçamento. A análise do segundo maior fator que impede o consumidor a ter acesso a produtos orgânicos, está na necessidade de satisfazer os desejos pessoais. O público que não consome orgânicos evidencia ter dificuldade em encontrar produtos de sua preferência, um grande impeditivo relacionado ao comportamento do consumidor brasiliense, onde muitos não respeitam a oferta de produtos a partir da época, sua sazonalidade.

Quando a análise comtempla aqueles que consomem produtos orgânicos com frequência, estes se sentem satisfeitos, e demonstram um cenário inverso. Pertencem predominantemente as classes A e B, e demonstram ser preocupados com a saúde, riqueza nutricional, sabor, aparência e aspecto visual, origem do produto, valorizam aspectos relacionados a atributos específicos do produto, características relacionadas aos valores subjetivos de compra. Os 
consumidores de orgânicos não utilizam o fator preço como determinante no momento de compra e respeitam a sazonalidade dos produtos. Para esse consumidor, a agricultura orgânica oferece maior saúde, confiabilidade e consequentemente a percepção de qualidade do produto, além de criar um valor cultural de preservação do meio ambiente. Os produtos são certificados, criar-se uma aproximação do consumidor com o produtor, com a oferta de informações de plantio, colheita, vivência do produtor para garantia da saúde e segurança alimentar do consumidor.

Quando se relaciona o nível de competitividade dos canais de comercialização de produtos orgânicos no Distrito Federal é possível observar a feira sendo o principal local de compra, seguido pelas vendas em supermercados e hipermercados, empórios, CSA, e internet. Os principais fatores relacionados a competitividade que o consumidor leva em consideração no momento de compra estão relacionados a limpeza do ambiente, origem do produto, aparência do produto, qualidade do atendimento, sensação de segurança, os fatores menos importantes estão relacionados a conhecer os funcionários e os donos do estabelecimento. Preço continua sendo o maior fator de influencia do consumidor, determinante para tornar o ambiente de compra competitivo. Além de correlacionar características como a presença de descontos, promoções, e a sensação de economia no momento de compra. A variedade e disponibilidade de produtos, a sensação e economia no momento de compra impactam diretamente na competitividade dos canais de comercialização.

Sob a perspectiva da comunidade, a agricultura orgânica incentiva o desenvolvimento socioeconômico por meio da geração de empregos, inclusão social, permanência e circulação do capital da região produtora. Para o governo incentiva-se a geração de emprego, desenvolvimento econômico, políticas de incentivo comercial, e o mais importante a preservação ambiental dos recursos disponíveis.

Quando se analisa a viabilidade da cooperativa percebe-se a oportunidade de atender as preferências dos dois públicos. A cooperativa propõe a oferta de conhecimento e produtos orgânicos de qualidade, juntamente com a cobrança de valores acessíveis, contato direto com o produtor, respeito a sazonalidade de produção. 
Os steakholders como pessoas influenciadoras, e tomares de decisão do mercado de orgânicos, se mostraram interessados, e receptivos a ideia do mercado de consumidores de orgânicos no Distrito Federal. Analisaram suas características detalhadamente e evidenciaram suas opiniões, com o objetivo de melhorar o projeto apresentado. Com as sugestões apontadas por cada um deles é possível tornar o projeto viável, melhorar sua estrutura física, organizacional, de recursos humanos, rentabilidade, armazenagem e logística, fazer previsão de compra, se preparar para a possível falta de alguns produtos. A apresentação do projeto norteou o entendimento dos entrevistados quanto ao seu objetivo que é gerar benefícios relacionados ao ambiente de consumo. A cooperativa torna popular e acessível os produtos orgânicos, oferece um preço justo, cria possibilidades de diversificação dos seus produtos no DF, e no mercado regional, e sugere uma nova alternativa ao consumidor com objetivo de minimizar as barreiras impostas por grandes varejistas.

Como sugestão de estudos futuros propõe-se o aprofundamento da análise dos consumidores de produtos orgânicos a partir da implementação de canais de comercialização alternativos, que aproximem o consumidor do produtor rural, com o mínimo de interferência varejista, como por exemplo: comunidades que sustentam a agricultura, associações e cooperativas de consumidores de produtos orgânicos. É interessante também aprofundar o estudo de viabilidade da cooperativa a partir das sugestões apresentadas pelos steakholders, com o intuito de implementar a cooperativa. 


\section{REFERÊNCIAS}

ALMEIDA IL; JUNQUEIRA AMR. 2012. Evolução do perfil dos consumidores de hortaliças orgânicas em Brasília - DF. Horticultura Brasileira 30: S765-S772, 2012.

ANGELO, Claudio; SILVEIRA, José. Varejo Competitivo. 1. ed. São Paulo: Atlas, 1999.

ALTIERI, M. A. Entrevista. Agricultura Sustentável, Jaguariúna, v. 2, n. 2, p. 5-11, jul./dez. 1995.

ARAÚJO, Cidália; PINTO, Emília M. F.; LOPES, José; NOGUEIRA, Luís; PINTO, Ricardo. Métodos de Investigação em Educação. Instituto de Educação e Psicologia, Universidade do Minho, 2008. Disponível em: <http://grupo4te.com.sapo.pt/estudo_caso.pdf>. Acesso em: 08 de mar. 2016.

BARNEY, Jay; HESTERLY, William. Administração Estratégica e Vantagem

Competitiva. Tradução de ROSEMBERG, Mônica. 1. ed. São Paulo: Pearson / Prentice Hall, 2007.

BRASIL. Lei nº 10.831, de 23 de Dezembro de 2003. Dispõe sobre a agricultura orgânica e dá outras providências. Diário Oficial [da] República Federativa do Brasil, Brasília DF, 24 dez. 2003.

BRASIL. Ministério da Agricultura, Pecuária e Abastecimento. Cadeia produtiva de produtos orgânicos / Ministério da Agricultura, Pecuária e Abastecimento, Secretaria de Política Agrícola, Instituto Interamericano de Cooperação para a Agricultura; coordenadores Antônio Márcio Buainain e Mário Otávio Batalha. - Brasília : IICA : MAPA/SPA, 2007.

BROYDRICK, Stephen. Valorizando o Consumidor: Como Conquistar Clientes e Influenciar Mercados. Tradução de PINHEIRO, Mauro. 1. ed. São Paulo: Futura, 1997.

CERTO, C. Samuel; Administração estratégica: planejamento e implantação de estratégias. 3. ed. - São Paulo: Pearson Education do Brasil, 2010.

CERVEIRA, Ricardo; CASTRO, Manoel Cabral de. Consumidores de produtos orgânicos da cidade de São Paulo: características de um padrão de consumo. Informações econômicas.v.29, n. 12, São Paulo, 1999. 
CHIAVENATO, Idalberto. Empreendedorismo: Dando Asas ao Espírito Empreendedor. 2. ed. São Paulo: Saraiva, 2008.

COSTA, Eliezer Arantes. Gestão estratégica: da empresa que temos para empresa que queremos. 2. ed. São Paulo: Saraiva, 2007. CRESWELL, J. W. Projeto de Pesquisa: métodos qualitativo, quantitativo e misto. 3. ed. Porto Alegre: Artmed, 2010.

DAROLT, M.R. A sustentabilidade do sistema de agricultura orgânica: um estudo na região metropolitana de Curitiba. Curitiba, PR. Tese de Doutorado. UFPR/ParisVII, 310 p. 2000.

DOMINGUEZ, Sigfried Vasques. O valor percebido como elemento estratégico para obter lealdade dos clientes. Caderno de Pesquisas em Administração, São Paulo, v. 07, n. 04, out./dez. 2000.

EHLERS, E. Agricultura sustentável: origens e perspectivas de um novo paradigma. 2. ed. Guaíba: Agropecuária, 1999. 157 p.

ELL, Erica; SILVA, Denise Oliveira; NAZARENO, Eleusis Ronconi; BRANDENBURG, Alfio. Concepções de agricultores do Paraná sobre alimentação saudável. Revista Saúde Pública. 2012. p. 218-225.

EMBRAPA, 2007; Produção orgânica de hortaliças - Coleção de 500 perguntas e respostas O produtor pergunta e a Embrapa responde.

EMBRAPA, 2008; Circular Técnica 63 - Embrapa Hortaliças - Organização da propriedade no sistema orgânico de produção - Brasília Julho; 2008.

FIGUEIREDO; Elsio Antônio Pereira; SOARES, João Paulo Guimarães. Sistemas orgânicos de produção animal: dimensões técnicas e econômicas. Brasília. Julho; 2012.

FOLHA DE SÃO PAULO. Brasil prepara terreno para crescimento dos orgânicos. São Paulo, 17 out. 2000. Caderno Agrofolha.

FONSECA, Maria Fernanda de Albuquerque Costa. A institucionalização do mercado orgânico no mundo e no Brasil: uma interpretação. Tese (Desenvolvimento, Agricultura e Sociedade) - Instituto de Ciências Humanas e Sociais, Universidade Federal Rural do Rio de Janeiro, Rio de Janeiro, 2005. 
FONSECA, M. C. P.; SILVA, M. A. A. P.; SALAY, E. Atitudes dos consumidores com relação à compra de hortifrutícolas em hipermercados e feiras livres na cidade de CampinasSP. Cadernos de Ciência \& Tecnologia, Brasília, v. 16, n. 1, p. 87-113, 1999

ILBERY, B.; MAYE, D. Food supply chains and sustainability: evidence from specialist food producers in the Scottish/English borders. Land Use Policy, v. 22, n. 4, p. 331-344, out. 2005.

GALÃO, Fabiano P.; SOUZA, S. A. . Atributos valorizados pelos consumidores na escolha de um supermercado. In: Congresso internacional de Administração, 2015, Ponta Grossa. Congresso internacional de Administração, 2015.

GARCEZ, D.; MIELITZ NETTO, C. G. A. Sistemas de produção de base ecológica: relocalização e reativação do espaço rural no litoral norte do Rio Grande do Sul. Agrária, n. 8, p. $23-48,2008$.

GIL, A. C. Como elaborar projetos de pesquisa. 5. ed. São Paulo: Atlas, 2010.

GIL, A. C. Métodos e técnicas e pesquisa social. 6. ed. São Paulo: Atlas, 2008.

HOPPE, Alexia; BARCELLOS, Marcia Dutra de; VIEIRA, Luciana Marques; MATOS, Celso Augusto de. Comportamento do Consumidor de Produtos Orgânicos: Uma Aplicação da Teoria do Comportamento Planejado. Revista Base (Admnistração e Contabilidade) da UNISINOS, abr./jun. 2012.

HOOLEY, Graham; SAUNDERS, John. Posicionamento Competitivo: Como Estabelecer e Manter uma Estratégia de Marketing no Mercado. Tradução de LISKE, Luiz. 1. ed. São Paulo: Makron Books, 1996.

IPARDES; O mercado de orgânicos no Paraná : caracterização e tendências / Instituto Paranaense de Desenvolvimento Econômico e Social e Instituto Agronômico do Paraná. Curitiba : IPARDES, 2007.

KARSAKLIAN, Eliane. Comportamento do Consumidor. 2. ed. São Paulo: Atlas, 2013. KLEIN, Adriano Diego. Cadeia de Produtos Orgânicos em Cooperativas de Consumo de SC e RS. Dissertação (Agronegócios) - Centro de Estudos e Pesquisas, Universidade Federal do Rio Grande do Sul, Porto Alegre - RS, 2014. 
KOTLER, Philip. Administração de Marketing: Análise, Planejamento, Implementação e Controle. 5. ed. São Paulo: Atlas, 1998.

KOTLER, Philip; KELLER, Kelvin Lane. Administração de Marketing. Tradução Yamamoto, Sônia Midori. 14. ed. São Paulo: Pearson Education do Brasil, 2012.

LARENTIS, Fabiano. Comportamento do Consumidor. Curitiba, PR: IESDE, 2012. 192p.

LEVITT, Theodore. The Marketing Imagination. 1. Ed. Nova Iorque: The Free Press, 1986.

MORAES, Mirian Lorena1; GUILHERME, Denilson de Oliveira1; FERNADES, Fernanda Matos de Brito1; CASAGRANDE, Vitor Melo Godoy1; MELO, Anthony Melo Silva Vaz1; DE PAIVA, Auricleia Sarmento1; CEREDA, Marney Pascoly. Análise do Perfil dos Consumidores de Produtos Orgânicos de Campo Grande, Mato Grosso do Sul. Agroecol. Dourados- MS. 2014.

MOWEN, John C; MINOR, Michael S. Comportamento do consumidor. Tradução de Jordan, Luiz. 1. ed. São Paulo: Pearson Prentice Hall, 2003.

NAMORADO, Rui. Cooperativismo - um horizonte possível. Coimbra - Portugal: Centro de Estudos Sociais. 2005. Disponível em: http://hdl.handle.net/10316/11126>. Acesso em: 20 de mar. 2016.

OLIVEIRA, Dario de Lima; QUEVEDO, Filipe. Percepção do consumidor sobre produtos orgânicos. Revista Brasileira de Marketing, vol. 11, núm. 1, enero-abril, 2012, pp. 29-46 Universidade Nove de Julho São Paulo, Brasil.

OLIVEIRA, Djalma de Pinho Rebouças. Planejamento Estratégico: Conceitos, Metodologia, Práticas. 31. ed. - São Paulo: Atlas, 2013.

OLIVEIRA, Priscila Silveira de. Canais de Comercialização de orgânicos: desafios e alternativas de agricultores familiares do leste paulista. Dissertação (Agroecologia e Desenvolvimento Rural) - Centro de Ciências Agrárias, Universidade Federal de São Carlos, Araras, 2014.

OLIVEIRA, Priscila Silveira de; MARJOTTA-MAISTRO, Marta Cristina. Canais de Comercialização de orgânicos: desafios e alternativas de agricultores familiares do leste 
paulista. Revista Brasileira de Gestão e Desenvolvimento Regional. V.12, n. 3 - Taubaté/SP, 2016.

ORMOND, José Geraldo Pacheco; PAULA, Sérgio Roberto Lima; FILHO VAVERET, Paulo; ROCHA, Luciana Thiabau M. Agricultura Orgânica: quando o passado é futuro. BNDES Setorial, Rio de Janeiro, n. 15, p. 3-34, mar. 2002.

PASCHOAL, A. D. Produção orgânica de alimentos: agricultura sustentável para os séculos XX e XXI. Piracicaba: Adilson D. Paschoal, 1994. 191 p.

PEROSA, J.M.; MOORI, R.G.; LOMBARDI, M.F.S.; PEROSA, B.B. O estímulo local e o consumo de produtos orgânicos em Botucatu, SP. Revista de Estudos Sociais, 2(22):59-77. 2009.

PETER, J. Paul. OLSON, Jerry C. Comportamento do Consumidor e Estrtégia de Marketing. Porto Alegre: AMGH, 2010.

PINHEIRO, Roberto et al. Comportamento do Consumidor e Pesquisa de Mercado. 3. ed. Rio de Janeiro: FGV, 2006.

PORTER, Michael. Estratégia Competitiva: Técnicas para Análise de Indústrias e da Concorrência. Tradução de BRAGA, Elizabeth. 7. ed. Rio de Janeiro: Campus, 1986. PORTER, Michael. Vantagem Competitiva: Criando e Sustentando um Desempenho Superior. Tradução de BRAGA, Elizabeth. 21. ed. Rio de Janeiro: Campus, 1989. PRODANOV, Cleber Cristiano; FREITAS, Ernani Cesar. Metodologia do trabalho científico: métodos e técnicas da pesquisa e do trabalho acadêmico. 2 ed. Rio Grande do Sul: Feevale, 2013.

RENTING, H.; MARSDEN, T. K.; BANKS, J. Understanding alternative food networks: exploring the role of short food supply chains in rural development. Environment and Planning A, v. 35, n. 3, p. 393-411, 2003.

RESENDE, 2007. Produção orgânica de hortaliças: o produtor pergunta, a Embrapa responde/ editores técnicos, Gilmar Paulo Henz, Flávia Aparecida de Alcântara,-- Brasília, DF: Embrapa Informação Tecnológica, 2007. 
REZENDE, C.L.; FARINA, E.M . Assimetria informacional do mercado de alimentos orgânicos. In: II Seminário Brasileiro da Nova Economia Institucional, 2001, Campinas. II Seminário Brasileiro da Nova Economia Institucional, 2001.

RICHARDSON, R. J.; PERES, J. A. S.; WANDERLEY, J. C. V.; CORREIA; PERES, M. H. M. Pesquisa social: métodos e técnicas. São Paulo: Atlas, 2010.

RODRIGUES, Marcia Aparecida; JUPI, Viviane da Silva. O comportamento do consumidor Fatores que influenciam na sua decisão de compra. Revista de Administração Nobel, n. 03, p.59-70, jan./jun. 2004.

SAMARA, Beatriz S.; MORSCH, Marco A. Comportamento do consumidor: conceitos e casos. São Paulo: Prentice Hall. 2005.

SOLOMON, Michael. O Comportamento do Consumidor: Comprando, Possuindo e Sendo. Tradução de FARIA, Luiz. 9. ed. Porto Alegre: Bookman, 2011.

SOUZA, Jacimar Luís de. Agricultura Orgânica: Tecnologia para a produção de alimentos saudáveis. Vitória, ES: EMCAPA, 1998. SILVA, Sandro Pereira. Políticas Públicas, Agricultura Familiar e Desenvolvimento Territorial. Caderno Gestão Pública e Cidadania, v.16. n. 58, São Paulo: 2011.

SOUZA, Jacimar Luis de; Manual de horticultura orgânica - 2. Ed. Atual. e ampl. - Viçosa, MG: Aprenda Fácil, 2006.

SÉRGIO, Saner e Moisés V. Balestro (orgs); 2005 - Agroecologia e os desafios da transição agroecológica.

SLACK, Nigel. Vantagem Competitiva em Manufatura: Atingindo Competitividade nas Operações Industriais. Tradução de CORRÊA, Sônia. 2. ed. São Paulo: Editora Atlas, 2002. SOLOMON, Michael. O Comportamento do Consumidor: Comprando, Possuindo e Sendo. Tradução de FARIA, Luiz. 9. ed. Porto Alegre: Bookman, 2011.

SOUZA, J. L., RESENDE, P. Manual de horticultura orgânica. 2. Ed. Viçosa, MG: Editora Aprenda fácil, 843p. 2006. 
STOLTENBORG, Joop. O que o consumidor dos orgânicos espera do produtor orgânico. 2011. Disponível em: http://www.aboaterra.com.br/produtor.php?id=40...produtor.. $>$. Acesso em: 19 de mar. 2016.

Trevizan SDP, Casemiro AD. Consumidores de produtos orgânicos em Vitória da Conquista, Bahia - BA. Key Elements For A Sustainable World: Energy, Water And Climate Change. São Paulo; Brazil; May 20th-22nd; 2009.

VENTURA, Rodrigo. Mudanças no perfil do consumo no Brasil: principais tendências nos próximos 20 anos. Macroplan - Prospectiva, Estratégia e Gestão. 2009. Disponível em: <http://www.macroplan.com.br/documentos/artigomacroplan2009103018108.pdf>. Acesso em: 20 de mar. 2016.

VERSIANI, Raíza de Oliveira. Percepção dos Consumidores e Tomada de Decisão na Compra de Alimentos Orgânicos: O Caso do Mercado Orgânico e da Feira da Agricultura Familiar / CEASA - Brasília/DF, 2016.

VIEIRA, Valter Afonso. Comportamento do Consumidor. Revista de Administração Contemporânea. 6. ed. Rio de Janeiro: Editora LTC, 2000.

VILAS BOAS, Luiz Henrique de Barros. Comportamento do Consumidor de Produtos Orgânicos: Uma Análise na Perspectiva da Teoria da Cadeia de Meios en Fins. Dissertação (Administração) - Departamento de Administraçãoe Economia, Universidade Federal de Lavras, Minas Gerais, 2005.

VILAS BOAS, Luis Henrique de Barros; SETTE, Ricardo de Souza; BRITO, Mozar José de. Comportamento do Consumidor de Produtos Orgânicos: Uma Aplicação da Teoria da Cadeia de Meios e Fins. Revista Organizações Rurais \& Agroindústriais, v. 8, n. 1, 2006.

VILAS BOAS, L.H. de B.; PIMENTA, M.L.; SETTE, R. de S. Percepções no consumo de alimentos orgânicos em supermercados: A influência de valores individuais como determinante de compra. Organizações Rurais \& Agroindustriais, Lavras, 10(2): p. 264278. 2008.

VILELA; Francisco - Organização da Propriedade no Sistema Orgânico de Produção; Francisco Vilela Resende Mariane Carvalho Vidal. 
VILELA, N.J.; RESENDE, F.V. de; GUIDUCCI FILHO E.; SAMINÊS, T. C.; VALLE J.C.V; JUNQUEIRA, L.P. Perfil dos consumidores de produtos orgânicos no Distrito Federal. Comunicado Técnico. EMBRAPA. Dezembro. 2006.

VIGLIO, Eliana Conde Barroso Leite. Produtos orgânicos uma tendência para o futuro? Agronalysys, 1996. Disponível em: <file:///C:/Users/User/Downloads/48428-96402-1PB.pdf>. Acesso em: 19 de mar. 2016.

WELLS, William; Reynolds, Fred. Consumer Behaviour. 1. ed. Nova Iorque: McGraw-Hill, 1977.

WILLER, H.; YUSSEFI, M. The World of Organic Agriculture - Statistics and Emerging Trends 2006. International Federation of Organic Agriculture Movements (IFOAM), Bonn, Germany, 2006.

WERNERFELT, Birger. A Resource-Based View of the Firm. 5. ed. Chicago: Strategic Management Journal, 1984. 


\section{APÊNDICE A - PROJETO}

\section{Apresentação da cooperativa}

O projeto do mercado de consumidores de produtos orgânicos surgiu no Departamento de Agricultura e Veterinária da Universidade de Brasília. O empreendedor Lucas Esmeraldo juntamente com a professora orientadora Ana Maria Resende Junqueira vislumbraram a oportunidade de criar um mecanismo que unisse os consumidores e produtores de produtos orgânicos em uma nova proposta, que integrasse de forma única os produtores e consumidores de produtos orgânicos no Distrito Federal, diferente da forma tradicional de compra que geralmente envolve um intermediário.

A intenção é agrupar pessoas com mesmo interesse que façam parte das cotas da cooperativa, em troca de descontos no momento de compra, ou seja, todos os associados prestarão serviços a cooperativa em função de descontos concedidos a partir de horas voluntárias de trabalho não remunerado na cooperativa.

Após duas pesquisas realizadas neste trabalho, com intuito de conhecer o perfil dos consumidores de produtos orgânicos, seu nível de satisfação com os produtos, seus hábitos de consumo, e o mercado concorrencial deu-se início o projeto com o desenvolvimento do presente plano de negócio com objetivo de suprir as principais dificuldades deste mercado.

O modelo do negócio criado foi inspirado em algumas cooperativas de consumidores orgânicos instaladas e em pleno funcionamento no Brasil, como a EcoTorres (Rio Grande do Sul), Rede Moinho (Bahia), Rede Ecológica (Rio de Janeiro). Da mesma forma que os estabelecimentos tradicionais de venda de produtos orgânicos como, feiras, supermercados, hipermercados, atacados, e CSAs a cooperativa busca inovar a relação de consumo, propondo um novo modelo de comercialização de produtos orgânicos. A cooperativa de consumidores une consumidores com interesses comuns.

A Cooperativa tem como propósito ser inovadora no ramo de autosserviço, onde o próprio cliente terá acesso aos produtores rurais para atender suas necessidades, evitando as limitações oferecidas pelos intermediários. O resultado esperado é um nível de satisfação maior do consumidor de orgânicos no Distrito Federal, com propostas que suprem as principais falhas apontadas nas pesquisas feitas neste trabalho. Será oferecido uma relação de pertencimento aos cooperados, por não serem apenas clientes e sim associados, com poder de decisão e a possibilidade de desempenhar atividades laborais no estabelecimento, uma maior diversidade de produtos, a um preço competitivo, sem a dependência de intermediários que podem aumentar os custos, as garantias de origem dos produtos oferecidos e práticas sustentáveis de produção. 
A cooperativa terá seu primeiro ponto localizado no centro de Brasília. Este trabalho optou por escolher o Bairro Sudoeste para ter uma projeção de custos e trabalhar com valores reais. A ideia da localização se deu pela a grande quantidade de consumidores de produtos orgânicos morando na região e a pela facilidade de acesso aos dados comerciais da região.

Em um mesmo modelo de cooperativa serão apresentados três formatos de venda, que irão variar de acordo com a disponibilidade de recursos financeiros e interesse dos cooperados. Os modelos terão exatamente a mesma estrutura interna, como a hierarquia, plano de cargos e salários, processos internos, horário de funcionamento, são padronizados independentemente do tamanho da cooperativa, mas a área de venda, o capital investido, o número de máquinas, equipamentos e funcionários, portifólio de produtos oferecidos irão variar de acordo com o modelo escolhido. O plano de negócios comtempla uma mercearia $\left(30 \mathrm{~m}^{2}\right)$, mercado $\left(150 \mathrm{~m}^{2}\right)$, e um supermercado $\left(300 \mathrm{~m}^{2}\right)$.

O objetivo da empresa é de futuramente ampliar sua área de atendimento e estar presente em outras regiões, com intuito de propagar a alimentação saudável e tornar o produto orgânico acessível. Abaixo estão listadas algumas características do estabelecimento:

- Setor de atividade: Comercial;

- Ramo de atuação: Autosserviço;

-Forma jurídica: Cooperativa;

-Capital social: 20 cotas;

- Produto a ser comercializado: Produtos orgânicos no Geral;

- Horário de funcionamento: 06:00 às 00:00

- Classe social a ser atingida: A, B e C;

\subsection{Empreendedor Responsável}

Lucas Augusto Esmeraldo de Oliveira, CPF 720.240.031-68, solteiro, brasileiro, formando do curso de Administração de empresas no Instituto de Ensino Superior de Brasília - IESB. Com grande apreço por produtos orgânicos e motivação elevada para a abertura de um negócio no ramo, o empreendedor analisa o mercado em busca de oportunidades de negócio.

\subsection{Visão de futuro do Empreendedor}

A ideia inicial do empreendedor é consolidar o nome da marca no mercado alvo, estruturar e padronizar a empresa com a finalidade de expandir o modelo de cooperativa.

\subsection{Cooperativa de consumidores de produtos orgânicos}

Este capítulo tem como principal objetivo demonstrar as características de marketing, operacionais, logísticas e financeiras, de uma cooperativa de consumidores de produtos orgânicos implementada no Distrito Federal. 
A cooperativa de consumidores de produtos orgânicos é estruturada a partir da união de consumidores que buscam desenvolver atividades em conjunto. A cooperativa tem como premissa identidade de interesses entre seus membros, ação conjunta e voluntária, obtenção de um resultado útil e comum a todos os integrantes (SEBRAE, 2016).

\section{Plano de Marketing}

Este plano de marketing possui o propósito de apresentar a cooperativa, e direcionar as estratégias que a cooperativa terá ao ingressar no mercado de produtos orgânicos na cidade de Brasília. O marketing desenvolvido irá proporcionar a identidade da cooperativa, transformando-a em algo inovador. A seguir a apresentação do logotipo da cooperativa.

\subsection{Logotipo:}

Figura 1: Logotipo Cooperativa de Consumidores.

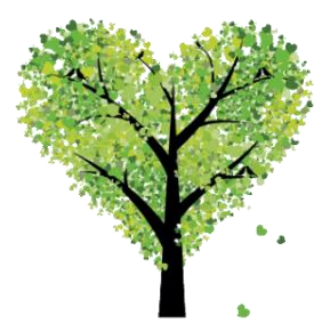

Cooperativa de Consumidores

Produtos Orgânicos do DF

Fonte: Elaborado pelo autor.

O logotipo tem como objetivo apresentar características essenciais da cooperativa, que reforçam seus valores e busca criar uma identidade com seu público alvo. A cor utilizada juntamente com a arvore em forma de coração ressaltam a necessidade de respeito a natureza. Características como a simplicidade, o respeito e a preservação ambiental são evidenciados na imagem juntamente com a descrição do estabelecimento, que restringe a uma cooperativa de consumidores de produtos orgânicos do Distrito Federal.

Abaixo serão apresentados a estratégia central da cooperativa, com a descrição da missão, visão e valores da organização.

2.1.1 Missão: Proporcionar aos nossos cooperados uma experiência única de pertencer a um mercado justo e sustentável.

2.1.2 Visão: Ser uma cooperativa de referência na comercialização de produtos orgânicos no Distrito Federal.

2.1.3 Valores: Meritocracia, responsabilidade socioambiental, foco no desenvolvimento de pessoas, com processo de melhoria contínua, criatividade e inovação. 
A determinação da estratégia central cria sentido e direcionamento para os objetivos da cooperativa. A missão evidencia o motivo de existência da cooperativa, a visão possibilita determinar objetivos quantificáveis para a cooperativa, os valores geram harmonia organizacional e reforçam a cultura organizacional.

\subsection{Caracterização do empreendimento}

O empreendimento em questão busca suprir uma área carente do comercio do Distrito Federal que é a venda produtos orgânicos de alta qualidade, a um preço acessível na cidade de Brasília. A cooperativa investe em um modelo de negócio com foco na colaboração do próprio consumidor para desempenhar atividades laborais para manutenção do empreendimento, em prol de descontos concedidos em suas compras.

Com o objetivo de atingir consumidores de produtos orgânicos que buscam pagar um preço justo, a cooperativa escolheu um método de comercio direto. Ou seja, uma loja em um ponto físico estabelecido, aberta para seus cooperados em dia e horário pré-determinados, onde será possível a escolha dos produtos orgânicos com garantia de origem, qualidade e preço justo.

O público alvo que a empresa pretende atingir é composto pelas classes A, B e C, uma vez que o produto possui grande aceitação em todas as classes e terá um preço acessível em virtude principalmente da redução de custos. Mesmo atingindo as três classes sociais a empresa terá o foco principal voltado para a classe B e C, composta por famílias com renda menor de $\mathrm{R} \$ 2.000,00$, que corresponde a grande parcela da pesquisa que menos consomem produtos orgânicos.

\subsection{Benchmarking}

Com o intuito de atingir a melhor estratégia possível a Cooperativa fez uso do Benchmarking para analisar o mercado. A abordagem utilizada proporcionou uma comparação do processo de venda de uma cooperativa de consumidores de produtos orgânicos instalada em Torres - Rio Grande do Sul. O resultado da análise feita a partir da comparação entre os processos de comercialização da Eco Torres.

A cooperativa se localiza na Av. Gen. Osório, 158 - Centro em Torres no Rio Grande do Sul. Foi criada há dezessete anos atrás, em 2000, com objetivo de suprir uma necessidade dos moradores de Torres que tinham que se deslocar até Porto Alegre para ter acesso a produtos orgânicos. Na união de um grupo de doze consumidores resolveram criar uma cooperativa, fizeram uma reunião e fundaram a cooperativa. A ideia da cooperativa foi divulgada e cento e vinte pessoas se cadastraram, entre produtores e consumidores.

Foi estipulada uma anuidade para os participantes, um valor equivalente a $\mathrm{R} \$ 60,00$ (sessenta reais), e era concedido um desconto para compra dos cooperados, como a cooperativa 
era recente o desconto era maior do que os custos da cooperativa, o que tornava a cooperativa insustentável. A partir daí o desconto foi cortado, injetado recurso financeiro para reestruturação da cooperativa.

Tabela 10 - Entrevista EcoTorres.

\begin{tabular}{|c|c|}
\hline \multicolumn{2}{|l|}{ Quadro de entrevista } \\
\hline Cooperados & Número limitado de cooperados. \\
\hline Localização & $\begin{array}{l}\text { Buscou-se uma localização privilegiada para a } \\
\text { reestruturação da empresa. Hoje está se } \\
\text { encontra em um ponto privilegiado no centro } \\
\text { da cidade. }\end{array}$ \\
\hline Preço & $\begin{array}{l}\text { A formação de preço leva em consideração } \\
\text { uma margem pequena para manutenção dos } \\
\text { custos da cooperativa. }\end{array}$ \\
\hline \multirow{2}{*}{ Formas de pagamento } & Dinheiro, cartões de crédito e débito, cheque. \\
\hline & Aceitam parcelamento. \\
\hline \multirow[t]{2}{*}{ Divulgação } & $\begin{array}{l}\text { Foco em preservação ambiental. A divulgação } \\
\text { é feita pela internet (site e mídias sociais); }\end{array}$ \\
\hline & Apoio de centros de preservação ambiental. \\
\hline \multirow{4}{*}{ Principais dificuldades } & Gestão de estoque eficiente; \\
\hline & Burocracia da cooperativa; \\
\hline & $\begin{array}{l}\text { Incompreensão do público pela falta de alguns } \\
\text { produtos em virtude da época (mamão). }\end{array}$ \\
\hline & Durabilidade dos produtos. \\
\hline \multirow[b]{2}{*}{ Diferenciais competitivos } & Garantia de origem do produto; \\
\hline & $\begin{array}{l}\text { Cafeteria orgânica com produção interna, } \\
\text { produtos orgânicos, integral, área de interação }\end{array}$ \\
\hline Certificadores e auditoria & $\begin{array}{l}\text { Produtos "frescos"; Semi industrializados, } \\
\text { cafeteria, todos com certificação. "Preferimos } \\
\text { não vender a arriscar um produto sem } \\
\text { certificação". }\end{array}$ \\
\hline \multirow{2}{*}{ Fornecedores e processos } & Produtores previamente cadastrados; \\
\hline & Agenda com dias certos de entrega. \\
\hline \multirow[b]{2}{*}{ Concorrentes } & Sete lojas de produtos naturais; \\
\hline & $\begin{array}{l}\text { Oferecem menos produtos, são menos } \\
\text { estruturados. Apenas } 1 \text { oferece hortaliças. }\end{array}$ \\
\hline
\end{tabular}

Fonte: Elaborado pelo autor.

A EcoTorres se demonstrou uma referência como modelo de negócio. Foram evidenciados aspectos que podem minimizar os possíveis erros do mercado de consumidores de produtos orgânicos no Distrito Federal.

\section{Plano Operacional}

A cooperativa é composta por vários processos, que padronizam todas as suas áreas, e abrange a seguinte estrutura: a apresentação de todo organograma, o fluxo de processos, a adesão de um membro participante, o cadastro dos produtores rurais, 
Os processos são divididos em áreas de e seus respectivos responsáveis. O organograma da organização irá apresentar e descrever as áreas e suas principais atribuições.

\subsection{Organograma}

A cooperativa tem como organograma os cargos descritos que respeitam a legislação e mantém uma estrutura adequada e eficiente para manutenção do mercado de consumidores de produtos orgânicos. Os cargos são divididos da seguinte forma: assembleia geral, conselho fiscal e contábil, diretoria e conselho de administração, gerente de loja, tesoureiro, líderes de secção, repositores, serviços gerais, copa e caixas. Essa estrutura se mantem em todos os moldes da cooperativa, com exceção dos líderes de secção, serviços gerais e caixas em virtude das dimensões dos modelos apresentados, ou seja, quanto maior a área de venda maior será o número de caixas, por exemplo.

Figura 2: Organograma Cooperativa de Consumidores.

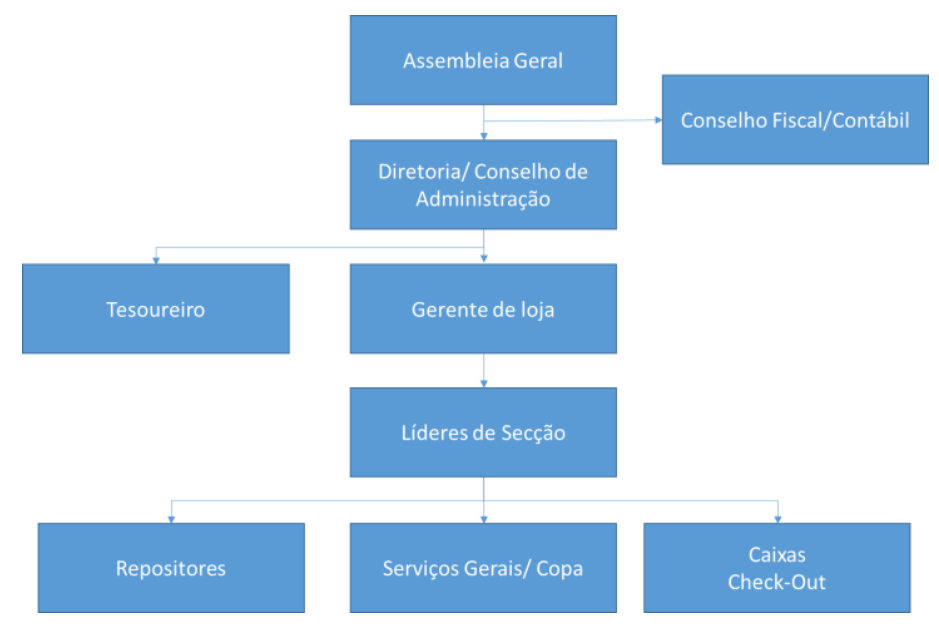

Fonte: Elaborado pelo autor.

Os cargos são estruturados com objetivo de hierarquizar e determinar responsabilidades para todos os participantes da cooperativa. Abaixo serão descritas as responsabilidades de cada cargo.

\subsection{Adesão e saída de membros participantes}

Os membros da cooperativa são divididos em 03 (três) categorias:

1. Cotistas;

2. Produtores;

3. Varejistas;

4. Atacadistas.

Cada uma das classificações terá um conjunto de responsabilidades determinadas pela assembleia geral. 


\subsubsection{Cotistas}

Os cotistas são parte integrante do contrato social da cooperativa. Os cotistas são divididos em: Cota Investidor, Cota Consumidor, Cota Produtor, Cota Atacadista. Nenhum cotista poderá ter mais de um terço do total de cotas distribuídas.

A cota investidor tem como principal característica a disponibilidade do recurso financeiro inicial para o início das atividades. O valor disponibilizado será ofertado como um empréstimo para no futuro ser resgatado com a disponibilidade de uma correção monetária. O objetivo é angariar fundo para que para implantação e capital de giro para os primeiros períodos da cooperativa. Essa cota não habilita ao consumo com desconto, e pode ser concedida por pessoa física, iniciativa privada, publica ou organizações não governamentais.

A cota consumidor destina-se a usuários frequentes da cooperativa, consumidores finais que irão pagar uma mensalidade e manter atividades laborais voluntárias em função da concessão de descontos na compra de alimentos. Estas cotas não comtemplam compras em atacado, e não garantem nenhum tipo de rentabilidade. Essa cota em condições ideias habilita os consumidores a participarem de cargo eletivos na estrutura organizacional da cooperativa.

A cota atacadista ou revendedor é destinada apenas ao terceiro modelo de cooperativa, com estrutura supermercadista, em virtude da capacidade de atendimento das outras lojas. Os donos de restaurantes e lanchonetes que tem uma estimativa de compra pré-definida, e que compartilham dos valores da cooperativa serão público-alvo da cota atacadista. Os atacadistas que compram em grandes quantidades terão descontos proporcionais a sua compra, e são expressamente proibidos de revender os produtos orgânicos para sua subsistência. A sua compra está condicionada a transformação do produto em um bem de valor agregado. $\mathrm{O}$ número de atacadistas é limitado, e depende do cadastro na cooperativa.

\subsubsection{Adesão}

A entrada de membros não estipula nenhuma restrição de público, contanto que respeite e aceite as condições de funcionamento da cooperativa, que são determinados a partir do pagamento ininterrupto das mensalidades e a impossibilidade de venda dos produtos para gerar vantagem comercial.

\subsubsection{Desligamento}

Os cooperados podem solicitar o desligamento da rede com pelo menos 1 mês de antecedência, sendo este formalizado pessoalmente ou por e-mail. Em caso do não cumprimento das atividades estipuladas pela cooperativa, o cooperado poderá ser desligado por determinação de sua assembleia geral. 


\subsubsection{Agenda de trabalho voluntário}

Os cooperados tem como obrigação disponibilizar horas de trabalho para a cooperativa. As horas de trabalho são divididas de acordo com a necessidade da cooperativa, as funções escolhidas e a disponibilidade do cooperado. As horas de trabalho na cooperativa são convertidas em descontos nos produtos, ou seja, quanto maior o horário disponibilizado na cooperativa maior o desconto proporcional nos produtos.

Figura 3- Agenda de Trabalho Voluntário Cooperativa de Consumidores.

\begin{tabular}{|c|c|c|c|c|c|c|}
\hline SEGUNDAFEIRA & TERCCA-FEIRA & QUARTA-FEIRA & QUINTA-FEIRA & SEXTAFEIRA & SABADO & DOMINGO \\
\hline 31 & 01 & 02 & $\begin{array}{l}03 \\
\text { Horário - Caixa }\end{array}$ & 04 & $\begin{array}{l}05 \\
\text { Horário - Caixa }\end{array}$ & 06 \\
\hline 07 & 08 & $\begin{array}{l}09 \\
\text { Horário - Caixa }\end{array}$ & 10 & $\begin{array}{l}11 \\
\text { Horário - Caixa }\end{array}$ & 12 & 13 \\
\hline 14 & $\begin{array}{l}15 \\
\text { Horário - Caixa }\end{array}$ & 16 & 17 & $\begin{array}{l}18 \\
\text { Horário - Caixa }\end{array}$ & 19 & 20 \\
\hline 21 & 22 & $\begin{array}{l}23 \\
\text { Horário - Caixa }\end{array}$ & 24 & 25 & 26 & 27 \\
\hline 28 & 29 & 30 & $\begin{array}{l}31 \\
\text { Horário - Caixa }\end{array}$ & 01 & 02 & 03 \\
\hline 04 & 05 & \multicolumn{5}{|c|}{$\begin{array}{l}\text { Anotaçōes: } \\
\text { Os horário disponibilizados no caixa serão convertidos em descontos na mensalidade e compras feitas na prórpria loja. } \\
\text { Ou seja, neste caso um cooperado trabalhou como caixa durante } 1 \text { hora em nove dias, um total de } 09 \text { horas de } \\
\text { trabalho disponibilizadas a cooperativa. }\end{array}$} \\
\hline
\end{tabular}

Fonte: Elaborado pelo autor.

A agenda de trabalho será disponibilizada 30 dias antes do mês de trabalho execução, ficará disponível durante 15 dias para candidatura de forma virtual, pelo site ou presencialmente na secretaria da cooperativa. Durante 5 (cinco) dias a cooperativa será responsável pelo lançamento da lista definitiva de trabalho para o próximo mês, com os nomes e responsáveis de cada área.

Figura 4 - Escala de trabalho dos cooperados.

ESCALA DE TRABALHO - MÊS DE __/2017

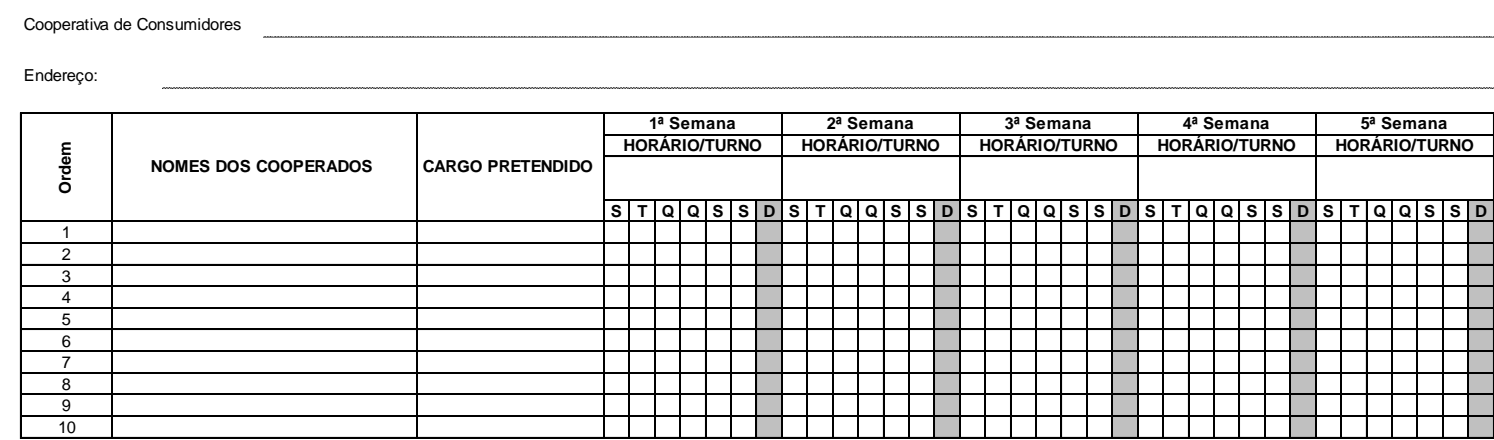

Fonte: Elaborado pelo autor. 
Os cotistas terão acesso aos cargos e os horários disponíveis para se cadastrarem, o não cumprimento do calendário pelo cotista incorrerá em multa. $\mathrm{O}$ calendário acima ilustra um exemplo de um cotista que se cadastrou para trabalhar de forma voluntária e não remunerada, se propôs a trabalhar como caixa durante uma hora por dia, no período de 09 (nove) dias, isso irá gerar um desconto proporcional na mensalidade ou nas compras realizadas durante o mês posterior.

Figura 5 - Folha de ponto dos cooperado.

FOLHA DE PONTO INDIVIDUAL DO COOPERADO

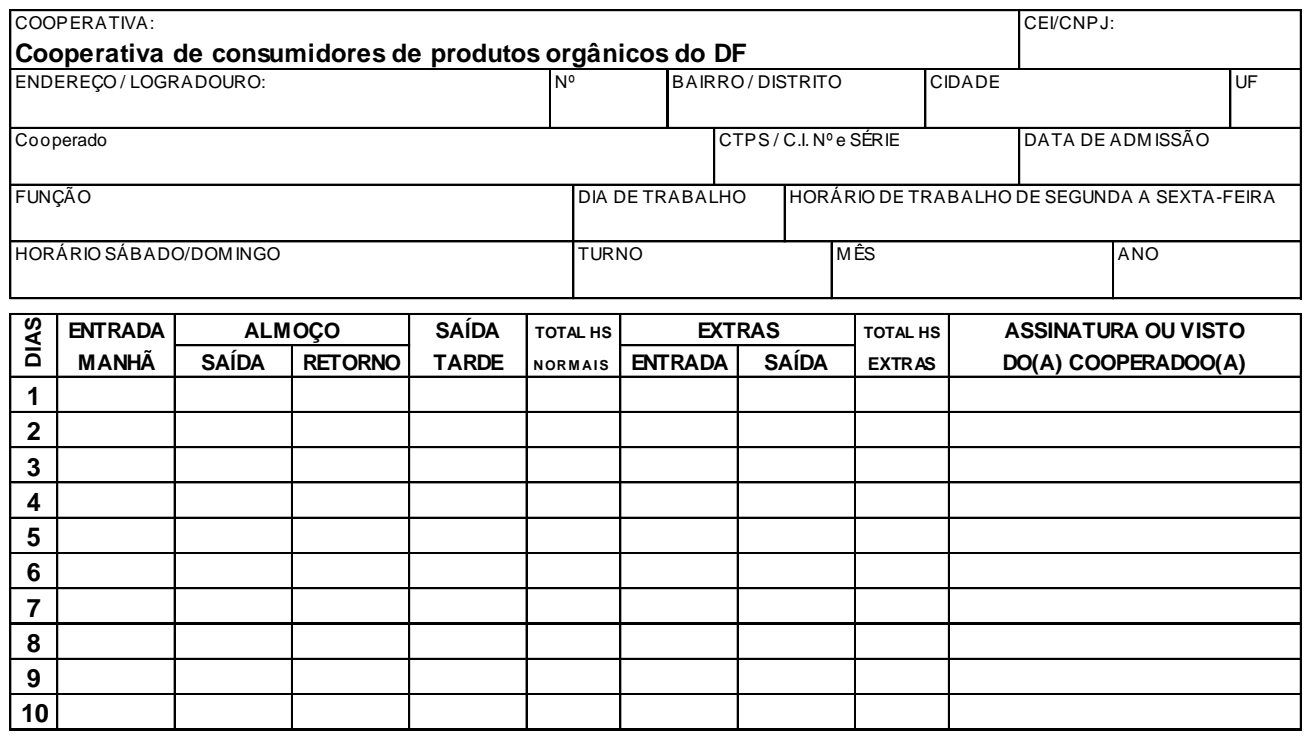

Fonte: Elaborado pelo autor.

Os cooperados terão que preencher uma folha de ponto nos dias de trabalho, com controle de horas de trabalho descriminando horário de entrada de manhã, saída para almoço, saída a tarde e o cumprimento de horas extras, conforme o modelo acima.

\subsubsection{Adesão de produtores rurais}

Os produtores rurais que desejarem participar do mercado de consumidores de produtos orgânicos dos Distrito Federal deverão preencher o formulário disponível no Apêndice. Os critérios de avaliação levados em consideração no momento de cadastro do produtor rural são:

1. Tempo de produção de produtos orgânicos;

2. Capacidade produtiva de produtos orgânicos;

3. Disponibilidade de entrega;

4. Número de empregos gerados;

5. Práticas produtivas empregadas na propriedade;

6. Diversidade de produção; 
Preenchido o formulário de intenção para participação da cooperativa, este será avaliado pela assembleia geral. Sendo aprovado o produtor terá uma quantia mínima ofertada periodicamente para suprimento da cooperativa. A não aprovação do cadastro do produtor tornará a vaga disponível para outro produtor. O número de produtores cadastrados dependerá exclusivamente da demanda, da diversidade de produtos oferecidos e da capacidade da cooperativa, quanto maior a demanda para um determinado produto maior deverá ser a capacidade produtiva do produtor e/ou maior será o número de produtores cadastrados.

Será necessário o cadastro de fornecedores fora da região do distrito Federal em virtude da capacidade produtiva limitada da região.

\subsubsection{Desligamento de produtores rurais}

Os produtores poderão solicitar o desligamento da cooperativa com um mês de antecedência. E esta solicitação deverá ser formalizada pessoalmente junto a comissão de cadastro, caso o produtor não respeite o cumprimento das obrigações dele será cobrado multa contratual.

\subsubsection{Varejistas}

O público em geral que não faz parte das cotas de cooperados, e também não são produtores orgânicos serão denominados varejistas, porém não possuem os benefícios, ou seja, a cooperativa não impede o livre acesso ao público em geral. Porém, o preço passa a ser considerado preço de varejo, sem benefício monetário.

\subsubsection{Mensalidade}

O preço cobrado pela cooperativa é destinado à manutenção de toda a sua estrutura. Os valores são destinados a mensalidade dos cooperados, não haverá cobrança de taxa inicial ou matrícula, apenas mensalidade.

As mensalidades são cobradas em todos os meses do ano, sendo assim, épocas festivas como Natal, Ano Novo e Carnaval não suspendem o pagamento de mensalidades.

Os cooperados que não pagarem sua mensalidade até a data limite será considerado não associado, e terá como prejuízo o pagamento do valor integral dos produtos, sem o desconto de associado. O cooperado tem apenas 2 meses para ajustar seus débitos, após esse período corre o risco de ser desligado da cooperativa.

\subsubsection{Arranjo físico}

O arranjo físico da loja tem como objetivo dimensionar as três possíveis estruturas para funcionamento da cooperativa, as quais busca otimizar os espaços disponíveis para torna-los amplos e adequados para o desempenho das atividades comerciais. Todas as lojas são 
semelhantes em diversos aspectos, sendo necessária, apenas, a decisão quanto a melhor estrutura física para a disposição da área de vendas.

\subsubsection{O projeto}

A primeira loja tem área total de $30 \mathrm{~m}^{2}$ e foi dimensionada para ter uma área de vendas para um fluxo menor de cooperados. A loja terá 03 (três) corredores, sendo ao total 05 (cinco) gôndolas de 1,98m. Além de uma fruteira lateral, medindo 2,4 metros de cumprimento, e um expositor refrigerado vertical com 02 (duas) portas. Além de um caixa de 1,30 metros e uma cadeira para atendente.

As gondolas foram dimensionadas para aproveitar da melhor maneira possível a área de venda, criando um fluxo de clientes que minimize momentos tumultos ou desconforto em um momento de maior demanda. A área de frutas, legumes e verduras, em virtude de seu grande fluxo ocupa uma área de maior dimensão e são posicionadas na porta de abertura da loja, o que irá proporcionar visibilidade para os produtos, e agilidade e fluidez no momento de compra. Como é possível observar na planta baixa da loja abaixo:

Figura 6 - Planta baixa e 3D Cooperativa de Consumidores $30 \mathrm{~m}^{2}$.
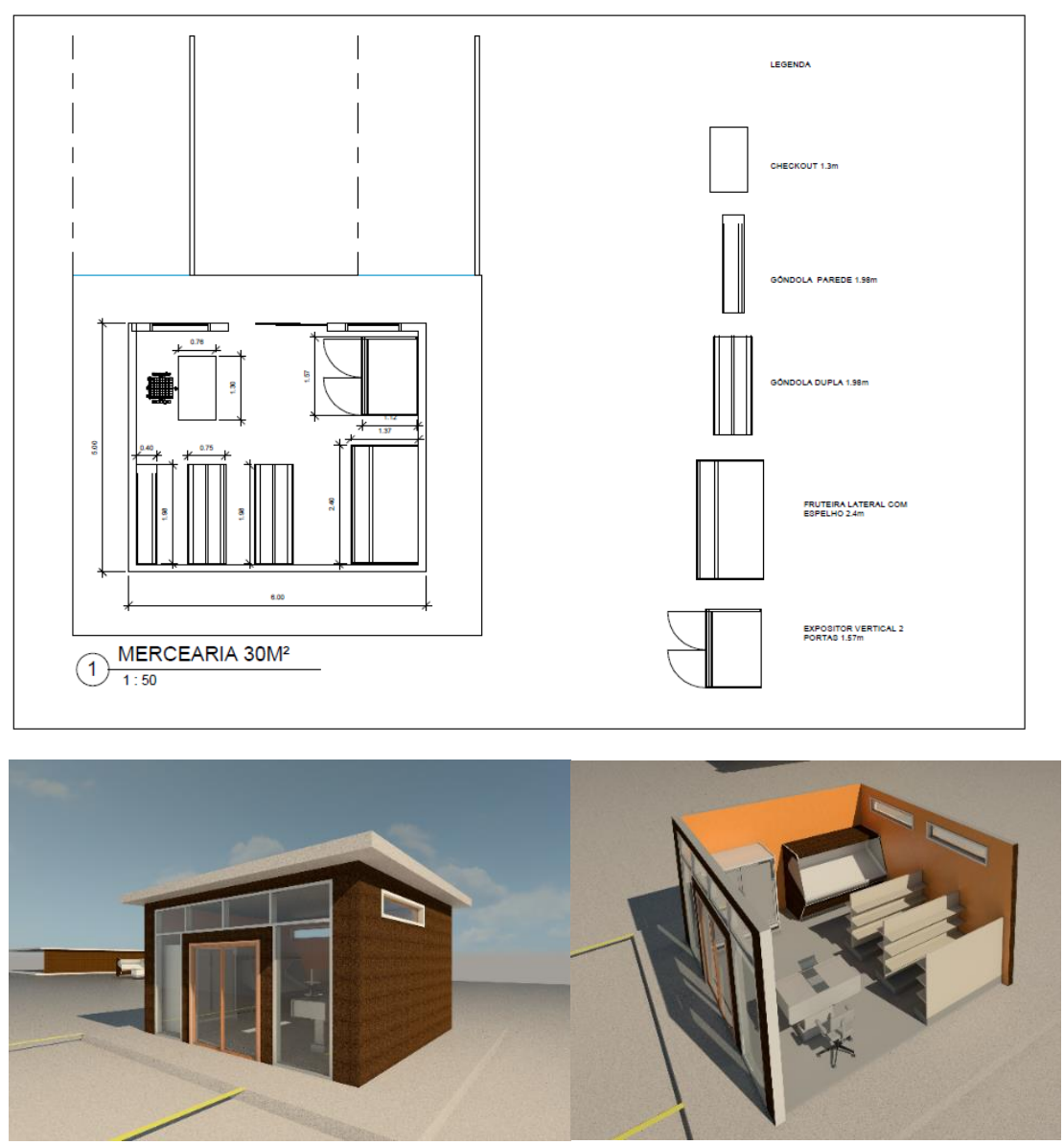

Fonte: Elaborado pelo autor. 
O segundo projeto é cinco vezes maior que a loja de $30 \mathrm{~m}^{2}$, ao total são $150 \mathrm{~m}^{2}$ de área comercial, destinada exclusivamente ao comércio de produtos orgânicos. Em uma área de exposição maior o consumidor terá a seu acesso 06 corredores de produtos distribuídos em áreas de interesse, com 22 prateleiras, de cumprimento igual a 1,98 cada. Ao total são 05 caixas para atendimento ao público, dois expositores para laticínios e frios, um expositor vertical, dois balcões refrigerados, duas ilhas para congelados, dois expositores verticais de duas portas e duas fruteiras lateral com espelho.

Figura 7 - Planta baixa e 3D Cooperativa de Consumidores $150 \mathrm{~m}^{2}$.
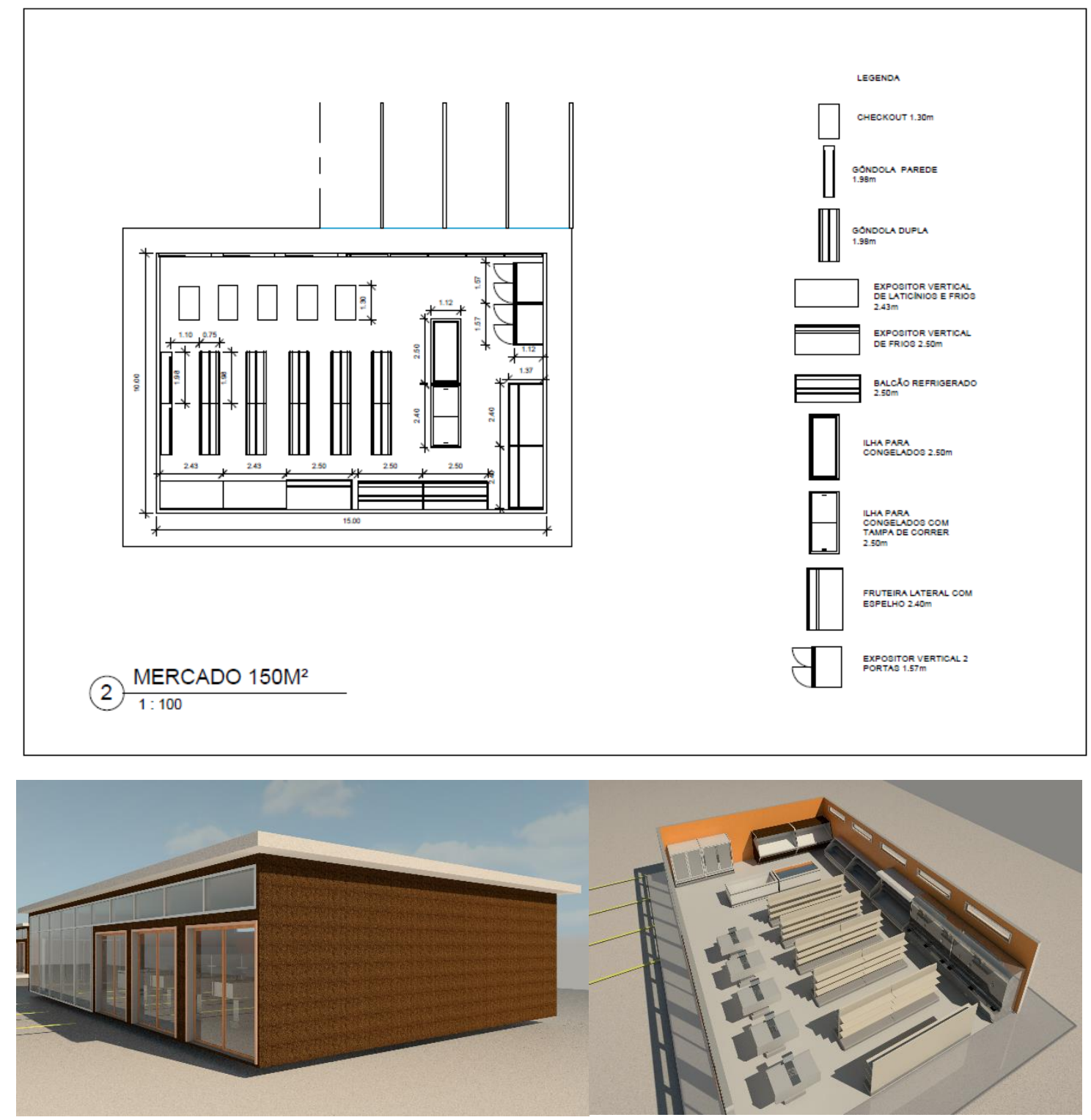

Fonte: Elaborado pelo autor.

O terceiro projeto diz respeito a um supermercado com área total de $300 \mathrm{~m}^{2}$, com a divisão do supermercado em setores de compra, como área de líquida, bazar, mercearia, frutas legumes e verduras, laticínios e higiene e limpeza. Ao total são 06 corredores com 40 gôndolas 
de 1,98 metros cada para exposição de produtos. Quatro expositores verticais com duas portas cada um, dois expositores de laticínios e frios, 2 expositores de frios, dois balcões refrigerados, uma ilha para congelados, duas ilhas para congelados com tampa de correr. Uma área de frutas, legumes e verduras com quatro fruteiras laterais com espelho e mais quatro fruteiras centrais. Além de ofertar 5 caixas para atendimento dos cooperados.

Figura 8: Planta baixa e 3D Cooperativa de Consumidores 300 $\mathrm{m}^{2}$.
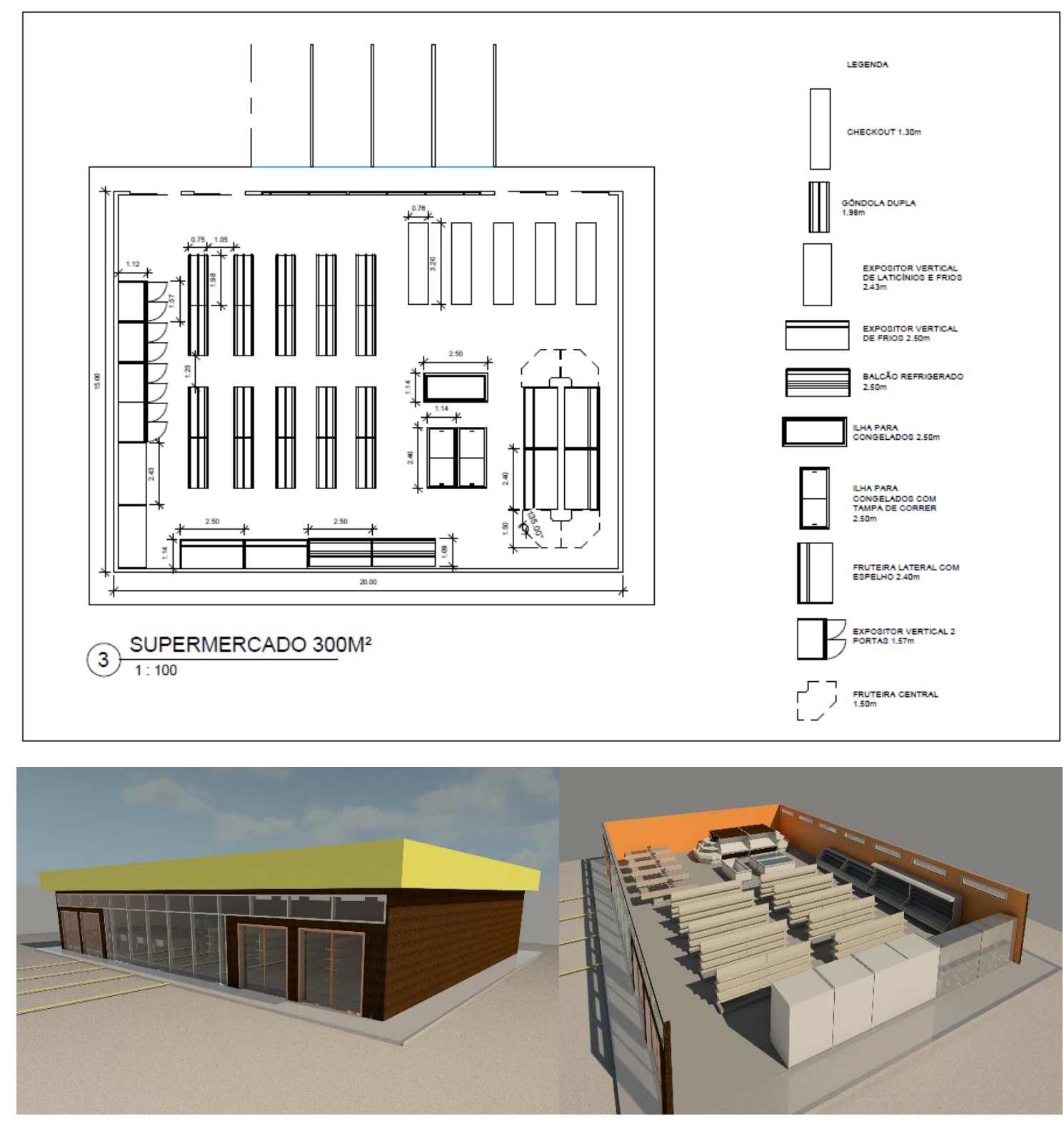

Fonte: Elaborado pelo autor.

As plantas foram desenvolvidas com o objetivo de otimizar a área interna da cooperativa e mensurar o valor do investimento inicial a área interna. Com essa estratégia é possível preservar o espaço interno, oferecer conforto, e mensurar com exatidão os custos relacionados a infraestrutura de três possíveis áreas de funcionamento da cooperativa de produtos orgânicos no Distrito Federal. 


\section{Plano de Recursos Humanos}

A empresa está ciente que seu ativo mais precioso é o capital humano, por isso desenvolveu algumas estratégias para que tenha o melhor ambiente de trabalho possível.Com o propósito de motivar os colaboradores e minimizar a rotatividade deles a empresa trabalhará com uma política de desempenho diferenciada juntamente com incentivos por cumprimento de metas.

\subsection{Descrição dos cargos}

Os cargos serão descritos quanto aos seus objetivos dentro da cooperativa, competências técnicas, competências estratégicas. O cargo será descrito quanto ao cargo, principais funções, pré-requisitos para ocupar o cargo, exigências e competências técnicas. A descrição de cada cargo se encontra abaixo.

Cargo: Repositor

Descrição: Realizar a precificação, comprovação de validade e acondicionamento da mercadoria, efetuando as anotações e controles necessários; Prestar o atendimento ao cliente, sugerindo, divulgando e promovendo a vendados produtos; Responder por sua seção, verificando a validade, limpeza, organização e qualidade dos produtos; Organizar as seções de acordo com o padrão de layout estabelecido, mantendo o endereçamento e planograma atualizados; Responder pela falta de produto, bem como o manuseio adequado e preços corretos dos mesmos; Analisar e acompanhar o giro dos produtos e os níveis de estoques, interagindo com o líder de mercearia; Cumprir com as normas internar de segurança e higiene; Atender com excelência; Atuar e coordenar os promotores de vendas.

Formatação: Ensino Fundamental;

Experiência: Mínima: 6 meses;

Competências técnicas: Processos e Rotinas; Administração Patrimonial; Recursos de Tecnologia da Informação; Administração do Tempo; Relacionamento Interno e Externo; Consciência do Contexto Organizacional; Comunicação Escrita.

Competências estratégicas: Trabalho em Equipe; Adaptação à Mudança; Iniciativa e Dinamismo; Conhecimento da Organização; Aquisição e Transferência de Conhecimentos; Foco no Cliente.

Competências de liderança: Exigido. Desenvolver liderança junto aos promotores de venda. Cargo: Caixa/ Checkout

Descrição: Atender com excelência; Registrar produto por produto; Efetuar a cobrança em espécie, cheques e outros; Manter a gaveta organizada e abastecida, e ainda, pedir troco para 
o cliente; Auxiliar no empacotamento dos produtos; Cumprir com as normas internas de segurança e higiene.

Formatação: Ensino Fundamental;

Experiência: Mínima: 6 meses;

Competências técnicas: Processos e Rotinas; Administração Patrimonial; Recursos de Tecnologia da Informação; Administração do Tempo; Relacionamento Interno e Externo; Consciência do Contexto Organizacional; Comunicação Escrita.

Competências estratégicas: Atenção concentrada; Memória visual; Percepção; Comunicação; Relacionamento interpessoal; Raciocínio numérico; Dinamismo.

Competências de liderança: Não exigido.

Cargo: Serviços gerais

Descrição: Atender com excelência; Auxiliar no empacotamento dos produtos; Cumprir com as normas internas de segurança e higiene. Executar serviços gerais de limpeza e conservação das instalações. Movimentar produtos, limpar, organizar e conservar o ambiente de trabalho. Carregar e descarregar material e realizar manutenção predial.

Formatação: Ensino Médio Completo

Experiência: Mínima: 1 ano;

Competências técnicas: Processos e Rotinas; Administração Patrimonial; Administração do Tempo; Relacionamento Interno e Externo;

Competências estratégicas: Qualidade no Trabalho; Organização; Agilidade; Relacionamento interpessoal Competências de liderança: Não exigido.

Cargo: Líder de seção

Descrição: Liderar com excelência;

Formatação: Ensino Superior Cursando/Completo

Experiência: Mínima: 1 ano;

Competências técnicas: Lidera e orienta as atividades de equipe; acompanha processos e produtividade da área; elabora relatórios de acompanhamento dos resultados.

Competências estratégicas: Flexível; Proativo; Ágil; Qualidade no Trabalho; Organização; Relacionamento interpessoal.

Competências de liderança: Pré-requisito para ocupação do cargo. Sua atividade tem como foco a liderança de grandes equipes.

Cargo: Gerente de loja

Descrição: Planejamento, organização, desenvolvimento, coordenação e controle de técnicas capazes de conquistar e manter os objetivos organizacionais. 
Formatação: Graduação/Pós-graduação

Experiência: Mínima: 3 anos;

Competências técnicas: Controle interno e externo da loja (cumprimento do horário de funcionamento, limpeza, organização, acessibilidade); Controle interno de funcionários (horário, apresentação, capacitação);

Controle de mercadorias (vencimento, perda, organização interna); Controle de estoque; Controle de pedidos e entregas; Planejamento de ações de marketing e publicidade; estipula e acompanha o atingimento de metas (globais e por seção); Mediador de conflitos; responsável por informações estratégicas da cooperativa;

Competências estratégicas: Flexível; Proativo; Ágil; Qualidade no Trabalho; Organização; Relacionamento interpessoal.

Competências de liderança: Pré-requisito para ocupação do cargo. Sua atividade tem como foco a liderança de grandes equipes.

Cargo: Tesoureiro

Descrição: Responsável pelo planejamento, organização, desenvolvimento, coordenação e controle de lançamentos e baixas referentes a recebimentos de toda a cooperativa.

Formatação: Graduação/Pós-graduação

Experiência: Mínima: 5 anos;

Competências técnicas: Atuar com rotinas administrativas e financeiras de tesouraria; Lançamentos contábeis e conciliações bancárias; Efetuar conferência do movimento financeiro, acompanhar orçamentos e do fluxo de caixa, Responsabilizar pela contabilidade, pelas contas e cobranças a receber ou a pagar, controle dos orçamentos, o fluxo financeiro e pela organização da caixa da cooperativa e aplicação de recursos financeiros, Competências estratégicas: Flexível; Proativo; Ágil; Qualidade no Trabalho; Organização.

Competências de liderança: Sugerido, mas não é uma exigência.

Cargo: Diretoria/Conselho de Administração

Descrição: Assegurar o cumprimento dos objetivos, promovendo a rentabilidade, crescimento e resultados definidos nos planos operacionais e administrativos da cooperativa.

Formatação: Graduação/Pós-graduação

Experiência: Mínima: 5 anos;

Competências técnicas: Supervisionar as operações da empresa para garantir a eficiência, qualidade, serviço e custo-eficaz na gestão dos recursos financeiros; Conduzir a elaboração e implementação dos planos estratégicos e operacionais, Identificar oportunidades, avaliar a viabilidade e fazer recomendações sobre novos investimentos ou desenvolvimento de novos 
negócios; Aprovar os procedimentos operacionais da empresa, políticas normativas, relatórios de atividade de revisão, demonstrações financeiras para determinar o progresso, o status na prossecução de objetivos, rever os objetivos e planos de acordo com as condições atuais; Avaliar o desempenho dos gerentes para o cumprimento das políticas estabelecidas, objetivos da empresa e contribuições para atingir objetivos; Promover a empresa através da mídia; Manter contatos com a direção de outras empresas, entidades de classe e órgãos governamentais, visando harmonizar esforços que se traduzam em benefícios para os clientes, o mercado e a comunidade em geral;

Competências estratégicas: Carisma; Liderança; Diplomacia; Comunicação; Relacionamento interpessoal;

Persuasão; Raciocínio numérico; Percepção; Mediador de conflitos.

Competências de liderança: Exigência.

Cargo: Conselho fiscal

Descrição: Assegurar o cumprimento dos objetivos, promovendo a rentabilidade, crescimento e resultados definidos nos planos operacionais e administrativos da cooperativa.

Formatação: Graduação/Pós-graduação

Experiência: Mínima: 5 anos;

Competências técnicas: Verificar se existem reclamações dos associados nos diversos assuntos da cooperativa;

Examinar livros e documentos; examinar balanços e balancetes; Convocar gerente e o contador para esclarecimentos; Convocar o Conselho de Administração (ou Diretoria), quando necessário; Examinar e dar parecer sobre a prestação de contas da Administração; Verificar o cumprimento da legislação cooperativista, trabalhista e fiscal; Participar ativa e efetivamente dos trabalhos da cooperativa. Planejar e traçar normas para as operações e serviços da cooperativa; Prestar contas e informar sobre as propostas e as limitações existentes;

Zelar pelo equilíbrio da cooperativa;

Competências estratégicas: Disponibilidade de tempo; Análise numérica; Minuciosidade; Ponderação e equilíbrio; Prudência.

Competências de liderança: Não é uma exigência.

\subsection{Estrutura salarial}

O salário de cada funcionário varia de acordo com seu cargo e nível profissional. A empresa terá metas de vendas quinzenais a ser atingidas em grupo com gratificações variadas. 


\subsubsection{Recrutamento e seleção}

A equipe de seleção usará as seguintes técnicas de recrutamento externo como:

a) Indicação de candidatos por parte de funcionários;

b) Linkedin;

c) Agências de recrutamento;

d) Anúncios em Jornais e listas de email.

A seleção da empresa se dará através dos seguintes passos:

a) Analise do currículo;

b) Entrevista pessoal;

c) Dinâmica de grupo;

d) Avaliação do trabalho.

\subsubsection{Avaliação de desempenho}

A avaliação de desempenho da empresa será feita de duas maneiras, avaliação interna pelos próprios colaboradores e gerente de caixa e avaliação por uma pessoa treinada para avaliar, de forma anônima, imparcial e objetiva, a qualidade percebida de atendimento e produtos, conhecida como cliente oculto.

\subsubsection{Treinamento e desenvolvimento}

A Cooperativa irá proporcionar para seus colaboradores oportunidades para que ele se desenvolva, em capacidades técnicas e habilidades relacionadas a cultura da cooperativa. Ao entrar na cooperativa o funcionário e o cooperado voluntário terão um treinamento especifico para o desenvolvimento do trabalho.

\subsubsection{Uniforme}

Todos os colaboradores terão que utilizar o uniforme fornecido pela cooperativa, composta por: calça jeans, bota com bico de aço (EPI), camiseta polo na cor branca e com a logo da cooperativa bordada do lado direito do peito disponibilizada pela empresa e um avental de cor verde bordada com a logo e o dia da semana a ser utilizado. O único colaborador que não irá precisar utilizar o avental será o que estiver operando o caixa da empresa.

\section{Plano Financeiro}

O plano financeiro diz respeito ao planejamento da cooperativa, cuja o objetivo é o planejamento financeiro e orçamentário para implementação e manutenção da cooperativa. $\mathrm{O}$ plano financeiro se faz importante para se ter uma projeção dos investimentos necessários, dos custos, das vendas, as quais direcionam vários outros parâmetros para tomada de decisão dos cooperados. 
Neste modelo é importante ressaltar que os valores correspondentes as receitas estão com os devidos descontos incidentes sobre as vendas, como impostos, e os valores projetados correspondem a quantidade máxima de produtos que podem ser realizados em um dia de venda na cooperativa, além de evidenciar possível descontos como perda de produtos.

A estimativa de investimentos para abertura da cooperativa foi dividida em três modelos que busca determinar o modelo de negócio mais viável para os consumidores de produtos orgânicos, onde é possível de forma comparativa encontrar um modelo adequado para um grupo de consumidores de produtos orgânicos.

A Tabela 11 - Custos Operacionais evidencia os gastos relacionados a implementação do modelo 01 de cooperativa, ou seja, correspondente a uma loja de $30 \mathrm{~m}^{2}$, preenchida com todos os acessórios necessário para funcionamento da loja.

Tabela 11 - Custos Operacionais mercearia $30 \mathrm{~m}^{2}$.

\begin{tabular}{|c|c|c|c|c|c|}
\hline \multicolumn{6}{|c|}{ MERCEARIA 30M² } \\
\hline \multicolumn{6}{|c|}{ Área de Venda } \\
\hline Item & Quantidade & \multicolumn{2}{|c|}{ Custo Unitário } & \multicolumn{2}{|c|}{ Valor Total } \\
\hline Checkout & 1 & $\mathrm{R} \$$ & $1.497,23$ & $\mathrm{RS}$ & $1.497,23$ \\
\hline Cadeira para caixa & 1 & $\mathrm{R} \$$ & 170,00 & $\mathrm{R} \$$ & 170,00 \\
\hline Impressora Fiscal & 1 & $\mathrm{R} \$$ & $1.400,00$ & $\mathrm{RS}$ & $1.400,00$ \\
\hline Gôndola Parede & 1 & $\mathrm{R} \$$ & 460,00 & $\mathrm{R} \$$ & 460,00 \\
\hline Gôndola dupla & 2 & $\mathrm{R} \$$ & 700,00 & $\mathrm{R} \$$ & $1.400,00$ \\
\hline Fruteira Lateral c/ Espelho & 1 & $\mathrm{R} \$$ & $2.190,00$ & $\mathrm{R} \$$ & $2.190,00$ \\
\hline Expositor Vertical de Frios & 1 & $\mathrm{R} \$$ & $9.990,00$ & $\mathrm{R} \$$ & $9.990,00$ \\
\hline Expositor Vertical 2 portas & 1 & $\mathrm{RS}$ & $3.730,00$ & $\mathrm{R} \$$ & $3.730,00$ \\
\hline Expositor Vertical de Frios e Laticinios & 0 & $\mathrm{RS}$ & $7.590,00$ & $\mathrm{RS}$ & - \\
\hline Balcão Refrigerado & 0 & $\mathrm{R} \$$ & $3.390,00$ & $\mathrm{R} \$$ & - \\
\hline Ilha para congelados & 0 & $\mathrm{RS}$ & $4.290,00$ & $\mathrm{R} \$$ & - \\
\hline Ilha para congelados $\mathrm{c} /$ tampa de correr & 0 & $\mathrm{R} \$$ & $1.333,00$ & $\mathrm{RS}$ & - \\
\hline Fruteira lateral com espelho & 0 & $\mathrm{R} \$$ & $2.190,00$ & $\mathrm{R} \$$ & - \\
\hline Fruteira central & 0 & $\mathrm{RS}$ & $4.410,00$ & $\mathrm{R} \$$ & - \\
\hline Cestinha Plastica & 20 & $\mathrm{R} \$$ & 29,00 & $\mathrm{R} \$$ & 580,00 \\
\hline Carrinho de supermercado duplo & 5 & $\mathrm{R} \$$ & 390,00 & $\mathrm{R} \$$ & $1.950,00$ \\
\hline \multicolumn{4}{|c|}{ TOTAL } & $\mathbf{R} \$$ & $23.367,23$ \\
\hline
\end{tabular}

Fonte: Elaborado pelo autor.

Os equipamentos da área de vendas custarão $\mathrm{R} \$ 23.367,23$ (vinte e três mil trezentos e sessenta e sete reais e vinte e três centavos aproximadamente. Nesse orçamento é possível observar a presença de 1 (um) caixa, uma cadeira, uma impressora fiscal, uma gôndola de parede, uma gôndola dupla, uma fruteira lateral, com espelho, um expositor vertical de frios, um expositor vertical duas portas, vinte cestas plásticas para transporte de compras, e cinco carrinhos de supermercado. 
Tabela 12 - Móveis e utensílios escritório da cooperativa.

\begin{tabular}{|c|c|c|c|c|c|}
\hline \multicolumn{6}{|c|}{ Moveis e utensílios } \\
\hline Descrição & Quantidade & & itário & & to Total \\
\hline Ar condicionado & 1 & $\mathrm{R} \$$ & $2.116,00$ & $\mathrm{R} \$$ & $2.116,00$ \\
\hline Computador & 1 & $\mathrm{R} \$$ & $2.000,00$ & $\mathrm{R} \$$ & $2.000,00$ \\
\hline Impressora para escritório (multifuncional) & 1 & $\mathrm{R} \$$ & $1.200,00$ & $\mathrm{R} \$$ & $1.200,00$ \\
\hline Cartucho & 1 & $R \$$ & 100,00 & $\mathrm{R} \$$ & 100,00 \\
\hline Aparelho telefônico & 1 & $\mathrm{R} \$$ & 180,00 & $\mathrm{R} \$$ & 180,00 \\
\hline Cadeira de escritório & 1 & $\mathrm{R} \$$ & 250,00 & $\mathrm{R} \$$ & 250,00 \\
\hline Mesa & 1 & $\mathrm{R} \$$ & 400,00 & $\mathrm{R} \$$ & 400,00 \\
\hline Purificador de água & 1 & $\mathrm{R} \$$ & 300,00 & $\mathrm{R} \$$ & 300,00 \\
\hline Relógio parede & 1 & $\mathrm{R} \$$ & 20,00 & $\mathrm{R} \$$ & 20,00 \\
\hline Lixeira & 5 & $\mathrm{R} \$$ & 25,00 & $\mathrm{R} \$$ & 125,00 \\
\hline Armário & 2 & $\mathrm{R} \$$ & 450,00 & $\mathrm{R} \$$ & 900,00 \\
\hline Utensílios diversos (escritório) & 1 & $\mathrm{R} \$$ & 200,00 & $\mathrm{R} \$$ & 200,00 \\
\hline \multicolumn{4}{|l|}{ Publicidade e propaganda } & $\mathrm{R} \$$ & $2.000,00$ \\
\hline \multicolumn{4}{|c|}{ TOTAL } & $\mathbf{R} \$$ & $9.791,00$ \\
\hline \multicolumn{4}{|l|}{ Estoque inicial + Enxoval } & $\mathrm{R} \$$ & $100.000,00$ \\
\hline \multicolumn{4}{|l|}{ Total Investimentos } & $\mathbf{R} \$$ & $133.158,23$ \\
\hline
\end{tabular}

Fonte: Elaborado pelo próprio autor.

Para compor o ambiente interno da cooperativa será necessário o investimento em móveis e utensílios, a Tabela 12 - Móveis e utensílios demonstra os insumos necessários para compor essa loja. Serão necessários: 1 ar condicionado 18 Btus, 1 computador, 1 impressora multifuncional, 1 cartucho, um aparelho telefônico, uma cadeira de escritório, uma mesa, um purificador de água, um relógio de parede, cinco lixeiras, dois armários, e um pequeno orçamento disponível para material de escritório. Será investido em publicidade e propaganda neste primeiro momento o valor de dois mil reais, otimizados em mídia social, e campanhas nas redondezas da loja.

O estoque inicial da loja tem orçamento de cem mil reais mais um enxoval concedido pelos fornecedores, neste caso produtor rural. O enxoval de fornecedores é uma prática do varejo e tem como objetivo divulgar a inauguração da loja e divulgação das principais marcas.

Ao total o custo estimado da cooperativa de $30 \mathrm{~m}^{2}$ tem orçamento de $\mathrm{R} \$ 133.158,23$, cento e trinta e três mil cento e cinquenta e oito reais e vinte e três centavos, com maquinários, gôndolas, primeiro estoque, verba disponível para publicidade e móveis e utensílios.

Em uma loja maior é possível observar um aumento proporcional de custos, neste caso a loja em questão tem área de venda equivalente a $150 \mathrm{~m}^{2}$, ou seja cinco vezes o tamanho da loja de $30 \mathrm{~m}^{2}$. É possível observar na Tabela 58, o aumento do investimento. 
Tabela 13 - Mercearia $150 \mathrm{~m}^{2}$ área de vendas.

\begin{tabular}{|c|c|c|c|c|c|}
\hline \multicolumn{6}{|c|}{ MERCEARIA $150 \mathrm{M}^{2}$} \\
\hline \multicolumn{6}{|c|}{ Área de Venda } \\
\hline Item & Quantidade & \multicolumn{2}{|c|}{ Custo Unitário } & \multicolumn{2}{|c|}{ Valor Total } \\
\hline Checkout & 5 & $\mathrm{R} \$$ & $1.497,23$ & $\mathrm{RS}$ & $7.486,15$ \\
\hline Cadeira para caixa & 5 & $\mathrm{R} \$$ & 170,00 & $\mathrm{R} \$$ & 850,00 \\
\hline Impressora Fiscal & 5 & $\mathrm{R} \$$ & $1.400,00$ & $\mathrm{R} \$$ & $7.000,00$ \\
\hline Gôndola Parede & 2 & $\mathrm{R} \$$ & 460,00 & $\mathrm{R} \$$ & 920,00 \\
\hline Gôndola dupla & 10 & 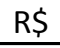 & 700,00 & $\mathrm{R} \$$ & $7.000,00$ \\
\hline Fruteira Lateral c/ Espelho & 2 & $\mathrm{R} \$$ & $2.190,00$ & $\mathrm{R} \$$ & $4.380,00$ \\
\hline Expositor Vertical de Frios & 1 & $\mathrm{R} \$$ & $9.990,00$ & $\mathrm{R} \$$ & $9.990,00$ \\
\hline Expositor Vertical 2 portas & 2 & 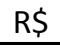 & $3.730,00$ & $\mathrm{R} \$$ & $7.460,00$ \\
\hline Expositor Vertical de Frios e Latic & 2 & $\mathrm{R} \$$ & $7.590,00$ & $\mathrm{R} \$$ & $15.180,00$ \\
\hline Balcão Refrigerado & 2 & $\mathrm{R} \$$ & $3.390,00$ & $\mathrm{R} \$$ & $6.780,00$ \\
\hline Ilha para congelados & 1 & $\mathrm{R} \$$ & $4.290,00$ & $\mathrm{R} \$$ & $4.290,00$ \\
\hline Ilha para congelados c/ tampa de & 1 & 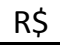 & $1.333,00$ & $\mathrm{R} \$$ & $1.333,00$ \\
\hline Fruteira lateral com espelho & 2 & $\mathrm{R} \$$ & $2.190,00$ & $\mathrm{R} \$$ & $4.380,00$ \\
\hline Fruteira central & 0 & $\mathrm{R} \$$ & $4.410,00$ & $\mathrm{R} \$$ & - \\
\hline Cestinha Plastica & 30 & $\mathrm{R} \$$ & 29,00 & $\mathrm{R} \$$ & 870,00 \\
\hline Carrinho de supermercado duplo & 10 & $\mathrm{R} \$$ & 390,00 & $\mathrm{R} \$$ & $3.900,00$ \\
\hline Camara fria & 1 & $\mathrm{R} \$$ & $8.856,00$ & $\mathrm{R} \$$ & $8.856,00$ \\
\hline \multicolumn{4}{|c|}{ TOTAL } & $\mathrm{R} \$$ & $90.675,15$ \\
\hline
\end{tabular}

Fonte: Elaborado pelo próprio autor.

Ao todo serão gastos na área de vendas $\mathrm{R} \$ 90.675,15$, noventa mil seiscentos e setenta e cinco reais e quinze centavos. $\mathrm{O}$ equivalente a: cinco caixas, cinco cadeiras para caixa, cinco impressoras fiscais, duas gôndolas de parede, dez gôndolas duplas, duas fruteiras lateral com espelho, um expositor vertical de frios, dois expositores verticais de frios com duas portas, dois expositores verticais de frios e laticínios, dois balcões refrigerados, uma ilha para congelados, uma ilha para congelados com tampa de vidro, duas fruteiras laterias com espelho, trinta cestinhas plásticas, dez carrinhos de supermercado e uma câmara fria média para garantir o estoque de itens perecíveis. Para compor a área de vendas serão necessários móveis e utensílios como descreve a Tabela 14. Ao todo o investimento é de $\mathrm{R} \$ 22.214,00$ vinte e dois mil duzentos e quatorze reais. 
Tabela 14 - Móveis e utensílios - Área de venda 150m².

\begin{tabular}{|c|c|c|c|c|c|}
\hline \multicolumn{6}{|c|}{ Moveis e utensílios - área de venda } \\
\hline Descrição & Quantidade & \multicolumn{2}{|c|}{ Custo Unitário } & \multicolumn{2}{|c|}{ Custo Total } \\
\hline Ar condicionado & 4 & $\mathrm{R} \$$ & $2.116,00$ & $\mathrm{R} \$$ & $8.464,00$ \\
\hline Computador & 5 & $\mathrm{R} \$$ & $2.000,00$ & $\mathrm{R} \$$ & $10.000,00$ \\
\hline $\begin{array}{l}\text { Impressora para escritório } \\
\text { (multifuncional) }\end{array}$ & 1 & $\mathrm{R} \$$ & $1.200,00$ & $\mathrm{R} \$$ & $1.200,00$ \\
\hline Cartucho & 1 & $\mathrm{R} \$$ & 100,00 & $\mathrm{R} \$$ & 100,00 \\
\hline Aparelho telefônico & 1 & $\mathrm{R} \$$ & 180,00 & $\mathrm{R} \$$ & 180,00 \\
\hline Cadeira de escritório & 1 & $\mathrm{R} \$$ & 250,00 & $\mathrm{R} \$$ & 250,00 \\
\hline Mesa & 1 & $\mathrm{R} \$$ & 400,00 & $\mathrm{R} \$$ & 400,00 \\
\hline Purificador de água & 1 & $\mathrm{R} \$$ & 300,00 & $\mathrm{R} \$$ & 300,00 \\
\hline Relógio parede & 1 & $\mathrm{R} \$$ & 20,00 & $\mathrm{R} \$$ & 20,00 \\
\hline Lixeira & 8 & $\mathrm{R} \$$ & 25,00 & $\mathrm{R} \$$ & 200,00 \\
\hline Armário & 2 & $\mathrm{R} \$$ & 450,00 & $\mathrm{R} \$$ & 900,00 \\
\hline Utensílios diversos (escritório) & 1 & $\mathrm{R} \$$ & 200,00 & $\mathrm{R} \$$ & 200,00 \\
\hline \multicolumn{4}{|c|}{ TOTAL } & $\mathbf{R} \$$ & $22.214,00$ \\
\hline
\end{tabular}

Fonte: elaborado pelo próprio autor.

Ao total serão necessários: quatro condicionadores de ar, cinco computadores, uma impressora multifuncional, um cartucho, um aparelho telefônico, uma cadeira de escritório, uma mesa, um purificador de ar, um relógio de parede, oito lixeiras, dois armários, e duzentos reais para caixa que compõe utensílios diversos.

Além dos custos para móveis e assessórios da loja será necessário o aluguel de uma sala de $30 \mathrm{~m}^{2}$ para ser o escritório da cooperativa. Nestes escritórios serão disponibilizados um ar condicionado, cinco computadores, duas impressoras, dois cartuchos, cinco mesas para escritório, cinco cadeiras, dois purificadores de água, um relógio de parede, cinco lixeiras, oito armários, e quatrocentos reais para utensílios diversos.

A verba de propaganda disponível para esse modelo de cooperativa é de dez mil reais, e a composição de seu estoque inicial é o equivalente a duzentos e cinquenta mil reais mais o enxoval que será negociado com fornecedores cadastrados.

Ao total a loja de $150 \mathrm{~m}^{2}$ mais o escritório tem valor aproximado de $\mathrm{R} \$ 396.500,15$, trezentos e noventa e seis mil e quinhentos reais e quinze centavos, conforme Tabela 60 descrita abaixo. 
Tabela15 - Custos escritório 30m².

\begin{tabular}{|c|c|c|c|c|c|}
\hline \multicolumn{6}{|c|}{ Escritório $\left(30 \mathrm{~m}^{2}\right)$} \\
\hline Descrição & Quantidade & & itário & & o Total \\
\hline Ar condicionado & 1 & $\mathrm{R} \$$ & $2.116,00$ & $\mathrm{R} \$$ & $2.116,00$ \\
\hline Computador & 5 & $\mathrm{R} \$$ & $2.000,00$ & $\mathrm{R} \$$ & $10.000,00$ \\
\hline $\begin{array}{lll}\text { Impressora para } & \text { escritório } \\
\text { (multifuncional) }\end{array}$ & 2 & $\mathrm{R} \$$ & $1.200,00$ & $\mathrm{R} \$$ & $2.400,00$ \\
\hline Cartucho & 2 & $\mathrm{R} \$$ & 100,00 & $\mathrm{R} \$$ & 200,00 \\
\hline Aparelho telefônico & 5 & $\mathrm{R} \$$ & 180,00 & $\mathrm{R} \$$ & 900,00 \\
\hline Cadeira de escritório & 5 & $\mathrm{R} \$$ & 250,00 & $\mathrm{R} \$$ & $1.250,00$ \\
\hline Mesa & 5 & $\mathrm{R} \$$ & 400,00 & $\mathrm{R} \$$ & $2.000,00$ \\
\hline Purificador de água & 2 & $\mathrm{R} \$$ & 300,00 & $\mathrm{R} \$$ & 600,00 \\
\hline Relógio parede & 1 & $\mathrm{R} \$$ & 20,00 & $\mathrm{R} \$$ & 20,00 \\
\hline Lixeira & 5 & $\mathrm{R} \$$ & 25,00 & $\mathrm{R} \$$ & 125,00 \\
\hline Armário & 8 & $\mathrm{R} \$$ & 450,00 & $\mathrm{R} \$$ & $3.600,00$ \\
\hline Utensílios diversos (escritório) & 2 & $\mathrm{R} \$$ & 200,00 & $\mathrm{R} \$$ & 400,00 \\
\hline \multicolumn{4}{|c|}{ TOTAL } & $\mathbf{R} \$$ & $23.611,00$ \\
\hline \multicolumn{4}{|l|}{ Publicidade e propaganda } & $\mathrm{R} \$$ & $10.000,00$ \\
\hline \multicolumn{4}{|l|}{ Total Investimentos } & $\mathbf{R} \mathbf{S}$ & $146.500,15$ \\
\hline \multicolumn{4}{|l|}{ Estoque inicial + Enxoval } & $\mathrm{R} \$$ & $250.000,00$ \\
\hline \multicolumn{4}{|l|}{ Total Investimentos } & $\mathbf{R} \$$ & $396.500,15$ \\
\hline
\end{tabular}

Fonte: Elaborado pelo autor.

Para o projeto de um supermercado de $300 \mathrm{~m}^{2}$ os investimentos iniciais estão dispostos na Tabela 16 - Supermercado $300 \mathrm{~m}^{2}$.

Tabela 16 - Supermercado $300 \mathrm{~m}^{2}$ - área de vendas.

\begin{tabular}{|c|c|c|c|c|c|}
\hline \multicolumn{6}{|c|}{ MERCEARIA 300M ${ }^{2}$} \\
\hline \multicolumn{6}{|c|}{ Área de Venda } \\
\hline Item & Quantidade & \multicolumn{2}{|c|}{ Custo Unitário } & \multicolumn{2}{|c|}{ Valor Total } \\
\hline Checkout & 5 & $\mathrm{R} \$$ & $1.497,23$ & $\mathrm{R} \$$ & $7.486,15$ \\
\hline Cadeira para caixa & 5 & $\mathrm{R} \$$ & 170,00 & $\mathrm{RS}$ & 850,00 \\
\hline Impressora Fiscal & 5 & $\mathrm{R} \$$ & $1.400,00$ & $\mathrm{R} \$$ & $7.000,00$ \\
\hline Gôndola Parede & 0 & $\mathrm{R} \$$ & 460,00 & $\mathrm{RS}$ & - \\
\hline Gôndola dupla & 20 & $\mathrm{R} \$$ & 700,00 & $\mathrm{R} \$$ & $14.000,00$ \\
\hline Fruteira Lateral c/ Espelho & 4 & $\mathrm{R} \$$ & $2.190,00$ & $\mathrm{R} \$$ & $8.760,00$ \\
\hline Expositor Vertical de Frios & 2 & $\mathrm{R} \$$ & $9.990,00$ & $\mathrm{RS}$ & $19.980,00$ \\
\hline Expositor Vertical 2 portas & 4 & $\mathrm{R} \$$ & $3.730,00$ & $\mathrm{RS}$ & $14.920,00$ \\
\hline Expositor Vertical de Frios e Laticinios & 2 & $\mathrm{R} \$$ & $7.590,00$ & $\mathrm{R} \$$ & $15.180,00$ \\
\hline Balcão Refrigerado & 2 & $\mathrm{R} \$$ & $3.390,00$ & $\mathrm{R} \$$ & $6.780,00$ \\
\hline Ilha para congelados & 1 & $\mathrm{R} \$$ & $4.290,00$ & $\mathrm{R} \$$ & $4.290,00$ \\
\hline Ilha para congelados c/ tampa de correr & 2 & $\mathrm{R} \$$ & $1.333,00$ & $\mathrm{R} \$$ & $2.666,00$ \\
\hline Fruteira lateral com espelho & 4 & $\mathrm{R} \$$ & $2.190,00$ & $\mathrm{RS}$ & $8.760,00$ \\
\hline Fruteira central & 2 & $\mathrm{R} \$$ & $4.410,00$ & $\mathrm{R} \$$ & $8.820,00$ \\
\hline Cestinha Plastica & 60 & $\mathrm{R} \$$ & 29,00 & $\mathrm{R} \$$ & $1.740,00$ \\
\hline Carrinho de supermercado duplo & 20 & $\mathrm{R} \$$ & 390,00 & $\mathrm{RS}$ & $7.800,00$ \\
\hline Camara fria & 1 & $\mathrm{R} \$$ & $15.000,00$ & $\mathrm{R} \$$ & $15.000,00$ \\
\hline \multicolumn{4}{|c|}{ TOTAL } & $\mathrm{RS}$ & $144.032,15$ \\
\hline
\end{tabular}

Fonte: Elaborado pelo próprio autor. 
O investimento inicial em maquinário e equipamentos para compor a loja de $300 \mathrm{~m}^{2}$ tem orçamento total de $\mathrm{R} \$ 144.032,15$, cento e quarenta e quatro mil e trinta e dois reais e quinze centavos. Para composição desta loja estima-se os seguintes equipamentos: cinco caixas, cinco cadeiras, cinco impressoras fiscais, vinte gôndolas duplas, quatro fruteiras lateral com espelho, dois expositores verticais de frios, quatro expositores verticais com duas portas, dois expositores verticais de frios e laticínios, dois balcões refrigerados, uma ilha para congelados, duas ilhas para congelados com tampa de correr, quatro fruteiras laterais com espelho, duas fruteiras centrais, sessenta cestinhas plásticas, vinte carrinhos de supermercado, e uma câmara fria.

Para compor os móveis e utensílios internos da loja destinados a área burocrática será necessário o investimento total de $\mathrm{R} \$ 22.214,00$, vinte e dois mil duzentos e quatorze reais. Distribuídos em: quatro condicionadores de ar, cinco computadores, uma impressora multifuncional, um cartucho, um aparelho telefônico, uma cadeira de escritório, uma mesa, um purificador de ar, um relógio de parede, oito lixeiras, dois armários, e duzentos reais para caixa que compõe utensílios diversos. Os valores são descriminados na Tabela 17, descrita abaixo.

Tabela 17 - Móveis e utensílios - Escritório da Cooperativa.

\begin{tabular}{|c|c|c|c|c|c|}
\hline \multicolumn{6}{|c|}{ Moveis e utensílios - área de venda } \\
\hline Descrição & Quantidade & \multicolumn{2}{|c|}{ Custo Unitário } & \multicolumn{2}{|c|}{ Custo Total } \\
\hline Ar condicionado & 4 & $\mathrm{R} \$$ & $2.116,00$ & $\mathrm{R} \$$ & $8.464,00$ \\
\hline Computador & 5 & $\mathrm{R} \$$ & $2.000,00$ & $\mathrm{R} \$$ & $10.000,00$ \\
\hline Impressora para escritório (multifuncional) & 1 & $\mathrm{R} \$$ & $1.200,00$ & $\mathrm{R} \$$ & $1.200,00$ \\
\hline Cartucho & 1 & $R \$$ & 100,00 & $\mathrm{R} \$$ & 100,00 \\
\hline Aparelho telefônico & 1 & $\mathrm{R} \$$ & 180,00 & $\mathrm{R} \$$ & 180,00 \\
\hline Cadeira de escritório & 1 & $\mathrm{R} \$$ & 250,00 & $\mathrm{R} \$$ & 250,00 \\
\hline Mesa & 1 & $\mathrm{R} \$$ & 400,00 & $\mathrm{R} \$$ & 400,00 \\
\hline Purificador de água & 1 & $\mathrm{R} \$$ & 300,00 & $\mathrm{R} \$$ & 300,00 \\
\hline Relógio parede & 1 & $\mathrm{R} \$$ & 20,00 & $\mathrm{R} \$$ & 20,00 \\
\hline Lixeira & 8 & $\mathrm{R} \$$ & 25,00 & $\mathrm{R} \$$ & 200,00 \\
\hline Armário & 2 & $\mathrm{R} \$$ & 450,00 & $\mathrm{R} \$$ & 900,00 \\
\hline Utensílios diversos (escritório) & 1 & $\mathrm{R} \$$ & 200,00 & $R \$$ & 200,00 \\
\hline \multicolumn{4}{|c|}{ TOTAL } & $\mathbf{R} \$$ & $22.214,00$ \\
\hline
\end{tabular}

Fonte: Elaborado pelo próprio autor.

Em virtude da dimensão da cooperativa de orgânicos vê-se a necessidade de criar um Escritório para auxiliar as operações burocráticas, de retaguarda de venda. O investimento necessário para compor esse escritório está descrito na Tabela 63, abaixo. 
Tabela 18 - Custo Escritório 30m².

\begin{tabular}{|c|c|c|c|c|c|}
\hline \multicolumn{6}{|c|}{ Escritório $\left(30 \mathrm{~m}^{2}\right)$} \\
\hline Descrição & Quantidade & \multicolumn{2}{|c|}{ Custo Unitário } & \multicolumn{2}{|c|}{ Custo Total } \\
\hline Ar condicionado & 1 & $\mathrm{R} \$$ & $2.116,00$ & $\mathrm{R} \$$ & $2.116,00$ \\
\hline Computador & 5 & $\mathrm{R} \$$ & $2.000,00$ & $\mathrm{R} \$$ & $10.000,00$ \\
\hline Impressora para escritório (multifuncional) & 2 & $\mathrm{R} \$$ & $1.200,00$ & $\mathrm{R} \$$ & $2.400,00$ \\
\hline Cartucho & 2 & $\mathrm{R} \$$ & 100,00 & $\mathrm{R} \$$ & 200,00 \\
\hline Aparelho telefônico & 5 & $\mathrm{R} \$$ & 180,00 & $\mathrm{R} \$$ & 900,00 \\
\hline Cadeira de escritório & 5 & $\mathrm{R} \$$ & 250,00 & $\mathrm{R} \$$ & $1.250,00$ \\
\hline Mesa & 5 & $\mathrm{R} \$$ & 400,00 & $\mathrm{R} \$$ & $2.000,00$ \\
\hline Purificador de água & 2 & $\mathrm{R} \$$ & 300,00 & $\mathrm{R} \$$ & 600,00 \\
\hline Relógio parede & 1 & $\mathrm{R} \$$ & 20,00 & $\mathrm{R} \$$ & 20,00 \\
\hline Lixeira & 5 & $\mathrm{R} \$$ & 25,00 & $\mathrm{R} \$$ & 125,00 \\
\hline Armário & 8 & $\mathrm{R} \$$ & 450,00 & $\mathrm{R} \$$ & $3.600,00$ \\
\hline Utensílios diversos (escritório) & 2 & $\mathrm{R} \$$ & 200,00 & $\mathrm{R} \$$ & 400,00 \\
\hline \multicolumn{4}{|c|}{ TOTAL } & $\mathbf{R} \$$ & $23.611,00$ \\
\hline \multicolumn{4}{|l|}{ Publicidade e propaganda } & $\mathrm{R} \$$ & $10.000,00$ \\
\hline \multicolumn{4}{|l|}{ Total Investimentos } & $\mathbf{R} \mathbf{\$}$ & $199.857,15$ \\
\hline \multicolumn{4}{|l|}{ Estoque inicial + Enxoval } & $\mathrm{R} \$$ & $400.000,00$ \\
\hline \multicolumn{4}{|l|}{ Total Investimentos } & $\mathbf{R} \$$ & $599.857,15$ \\
\hline
\end{tabular}

Fonte: Elaborado pelo próprio autor.

O investimento no escritório tem como valor total $\mathrm{R} \$ 23.611,00$, vinte e três mil seiscentos e onze reais, e será composto por: um ar condicionado, cinco computadores, duas impressoras, dois cartuchos, cinco aparelhos de telefone, cinco mesas para escritório, cinco cadeiras, dois purificadores de água, um relógio de parede, cinco lixeiras, oito armários, e quatrocentos reais para utensílios diversos.

A descrição dos custos do escritório para a loja de $300 \mathrm{~m}^{2}$ é idealizada para suportar o atendimento a fornecedores, sendo disponível uma área comercial para negociação de compras e possíveis acordos comerciais.

A verba de propaganda disponível para esse modelo de cooperativa é de dez mil reais que será investido em campanhas que contemplam mídia televisiva, rádio difusão e impressão e distribuição de tabloide.

A composição de seu estoque inicial é o equivalente a quatrocentos mil reais para estoque em loja, mais o enxoval concedido no mês de inauguração da loja.

\subsection{Custos Fixos Operacionais Mensais}

Para estimativa dos custos fixos operacionais mensais levantou-se os vencimentos essenciais para manutenção da loja. A estimativa levou em consideração os valores do aluguel, condomínio, água, energia elétrica, telefone e internet, honorários do contador, manutenção de equipamentos, salários e encargos, material de limpeza, material de escritório, possíveis perdas na loja, e o valor diluído mensalmente do IPTU. 
Para o cálculo utilizou-se como referência os valores reais, descriminam os custos do valor de aluguel, condomínio, energia elétrica, e IPTU, de uma loja equivalente de 30 metros quadrados, para as lojas de $150 \mathrm{~m}^{2}$ e $300 \mathrm{~m}^{2}$ utilizou-se um fator de proporcionalidade linear. $\mathrm{Na}$ estimativa de gasto com aluguel chegou-se ao valor de $\mathrm{R} \$ 115,96$ cento e quinze reais e noventa e seis centavos sendo valor do metro quadrado, ou seja, para uma loja de $30 \mathrm{~m}^{2}$ o valor do aluguel é a metragem da loja multiplicado pelo valor do metro quadrado. Para encontrar esse valor elegeu-se três lojas no bairro que se pretende abrir a cooperativa, e fez-se uma média do valor do metro quadrado de cada uma, para então conseguir levantar o custo médio do metro quadrado.

O valor do consumo de água, telefone e internet, honorários do contador, manutenção dos equipamentos, material de limpeza e escritório utilizou-se uma estimativa de custos a partir de um consumo médio de uma loja similar e busca em sítios de busca, como site de operadores de telefonia, conselho regional de contabilidade e pesquisas similares.

Tabela 19 - Custo fixo mensal mercearia $30 \mathrm{~m}^{2}$.

\begin{tabular}{|l|lr|}
\hline \multicolumn{3}{|c|}{ MERCEARIA 30M } \\
\hline Descrição & \multicolumn{2}{|c|}{ Custo total mensal (R\$) } \\
\hline Aluguel & $\mathrm{R} \$$ & $3.478,80$ \\
\hline Condomínio & $\mathrm{R} \$$ & 233,10 \\
\hline Água & $\mathrm{R} \$$ & 444,00 \\
\hline Energia elétrica & $\mathrm{R} \$$ & 229,85 \\
\hline Telefone + Internet & $\mathrm{R} \$$ & 260,00 \\
\hline Honorários do contador & $\mathrm{R} \$$ & 800,00 \\
\hline Manutenção dos equipamentos & $\mathrm{R} \$$ & 400,00 \\
\hline Salários + encargos & $\mathrm{R} \$$ & $19.502,29$ \\
\hline Material de limpeza & $\mathrm{R} \$$ & 200,00 \\
\hline Material de escritório & $\mathrm{R} \$$ & 150,00 \\
\hline Perda & $\mathrm{R} \$$ & 250,00 \\
\hline Total & $\mathrm{R} \$$ & $25.948,04$ \\
\hline IPTU & $\mathrm{R} \$$ & 161,00 \\
\hline Total + IPTU & $\mathbf{2 6 . 1 0 9 , 0 4}$ \\
\hline
\end{tabular}

Fonte: Elaborado pelo autor.

A loja de $30 \mathrm{~m}^{2}$ tem como valor total de custos fixos mensal de $\mathrm{R} \$ 26.109,04$, vinte e seis mil cento e nove reais e quatro centavos. 
Tabela 20 - Custo fixo mensal mercearia $150 \mathrm{~m}^{2}$

\begin{tabular}{|c|c|c|}
\hline \multicolumn{3}{|c|}{ LOJA 150M² } \\
\hline \multirow{2}{*}{$\begin{array}{l}\text { Descrição } \\
\text { Aluguel }\end{array}$} & \multicolumn{2}{|c|}{ Custo total mensal (R\$) } \\
\hline & $\mathrm{R} \$$ & $17.394,00$ \\
\hline Condomínio & $\mathrm{R} \$$ & $1.165,50$ \\
\hline Água & $\mathrm{R} \$$ & 444,00 \\
\hline Energia elétrica & $\mathrm{R} \$$ & 591,35 \\
\hline Telefone + Internet & $\mathrm{R} \$$ & 260,00 \\
\hline Honorários do contador & $\mathrm{R} \$$ & 800,00 \\
\hline Manutenção dos equipamentos & $\mathrm{R} \$$ & 400,00 \\
\hline Salários + encargos & $\mathrm{R} \$$ & $46.434,62$ \\
\hline Material de limpeza & $\mathrm{R} \$$ & 400,00 \\
\hline Material de escritório & $\mathrm{R} \$$ & 250,00 \\
\hline Perda & $\mathrm{R} \$$ & 400,00 \\
\hline Total & $\mathrm{R} \$$ & $68.539,47$ \\
\hline IPTU & $\mathrm{R} \$$ & 805,00 \\
\hline Total + IPTU & 69.3 & \\
\hline
\end{tabular}

Fonte: Elaborado pelo autor.

Para a loja de 150 metros quadrados o custo mensal estimado para manutenção da loja é de $\mathrm{R} \$ 69.344,47$ sessenta e nove mil trezentos e quarenta e quatro reais e quarenta e sete centavos.

Tabela 21 - Custo fixo mensal supermercado $300 \mathrm{~m}^{2}$

\begin{tabular}{|l|lc|}
\hline \multicolumn{3}{|c|}{ SUPERMERCADO 300M } \\
\hline Descrição & \multicolumn{2}{|c|}{ Custo total mensal (R\$) } \\
\hline Aluguel & $\mathrm{R} \$$ & $34.788,00$ \\
\hline Condomínio & $\mathrm{R} \$$ & $2.331,00$ \\
\hline Água & $\mathrm{R} \$$ & $1.000,00$ \\
\hline Energia elétrica & $\mathrm{R} \$$ & $1.083,71$ \\
\hline Telefone + Internet & $\mathrm{R} \$$ & 260,00 \\
\hline Honorários do contador & $\mathrm{R} \$$ & 800,00 \\
\hline Manutenção dos equipamentos & $\mathrm{R} \$$ & 400,00 \\
\hline Salários + encargos & $\mathrm{R} \$$ & $82.073,43$ \\
\hline Material de limpeza & $\mathrm{R} \$$ & 400,00 \\
\hline Material de escritório & $\mathrm{R} \$$ & 300,00 \\
\hline Perda & $\mathrm{R} \$$ & 250,00 \\
\hline Total & $\mathrm{R} \$$ & $123.686,14$ \\
\hline IPTU & $\mathrm{R} \$$ & $1.610,00$ \\
\hline Total + IPTU & $\mathbf{1 2 5 . 2 9 6 , 1 4}$ \\
\hline
\end{tabular}

Fonte: Elaborado pelo autor.

Para a loja de 300 metros quadrados serão necessários $\mathrm{R} \$ 125.296,14$ cento e vinte cinco duzentos e noventa e seis reais e quatorze centavos. 


\subsection{Custos de mão-de-Obra}

Os custos de mão de obra foram definidos a partir da descrição de todos os cargos que a cooperativa tem, a quantidade de funcionários, que depende do tamanho da loja, o valor do salário líquido, juntamente com os encargos sobre os salários. Para definição do valor dos salários multiplica-se a quantidade de funcionários pela soma do salário líquido mais impostos.

Para determinação dos cargos utilizou-se a legislação vigente em questão, Lei Geral do Cooperativismo. Para determinação dos cargos utilizou-se como base os Artigos 47 e 56, que relatam sobre os órgãos de administração e o conselho físcal. É necessário a presença de um diretor, eleito em assembleia geral com matado de quatro anos, e a possibilidade de reeleição, juntamente com o conselho fiscal, composto por no mínimo 03 eleitos em assembleia geral, onde apenas $1 / 3$ destes poderão ser reeleitos. Logo, tendo como base os salários de mercado estipula-se os custos de mão-de-obra segundo a necessidade da loja e as exigências legais.

Tabela 22 - Custos salários mercearia $30 \mathrm{~m}^{2}$.

\begin{tabular}{|c|c|c|c|c|c|c|c|}
\hline \multicolumn{8}{|c|}{ MERCEARIA 30m² } \\
\hline Cargos & Quantidade & \multicolumn{2}{|c|}{ Salários } & \multicolumn{2}{|c|}{ Encargos } & \multicolumn{2}{|c|}{ Custo total com salários } \\
\hline Diretoria & 1 & $\mathrm{R} \$$ & $6.580,00$ & $\mathrm{R} \$$ & $2.222,07$ & $\mathrm{R} \$$ & $8.802,07$ \\
\hline Conselho Fiscal & 3 & $\mathrm{R} \$$ & $2.500,00$ & $\mathrm{R} \$$ & 844,25 & $\mathrm{R} \$$ & $10.032,75$ \\
\hline Tesoureiro & 1 & $\mathrm{R} \$$ & $2.740,29$ & $\mathrm{R} \$$ & 925,39 & $\mathrm{R} \$$ & $3.665,68$ \\
\hline Gerente de Loja & 1 & $\mathrm{R} \$$ & $4.387,50$ & $\mathrm{R} \$$ & $1.481,66$ & $\mathrm{R} \$$ & $5.869,16$ \\
\hline Líderes de Secção & 0 & $\mathrm{R} \$$ & $3.287,05$ & $\mathrm{R} \$$ & $1.110,04$ & $\mathrm{R} \$$ & - \\
\hline Repositores & 2 & $\mathrm{R} \$$ & $1.569,28$ & $\mathrm{R} \$$ & 529,95 & $\mathrm{R} \$$ & $4.198,45$ \\
\hline Serviços Gerais & 2 & $\mathrm{R} \$$ & $1.424,60$ & $\mathrm{R} \$$ & 481,09 & $\mathrm{R} \$$ & $3.811,37$ \\
\hline Caixas & 1 & $\mathrm{R} \$$ & $1.463,43$ & $\mathrm{R} \$$ & 494,20 & $\mathrm{R} \$$ & $1.957,62$ \\
\hline \multicolumn{6}{|l|}{ Total } & $\mathrm{R} \$$ & $38.337,10$ \\
\hline
\end{tabular}

Fonte: Elaborado pelo autor.

A Tabela 22 descreve os cargos segundo organograma da cooperativa de $30 \mathrm{~m}^{2}$ composto por: um diretor, três conselheiros fiscais, um tesoureiro, um gerente de loja, dois repositores, dois serviços gerais e um caixa. A folha de pagamento mensal desta loja é equivalente a R\$ $38.337,10$ trinta e oito mil trezentos e trinta e sete reais e dez centavos. 
Tabela 23 - Custos salários loja $150 \mathrm{~m}^{2}$.

\begin{tabular}{|c|c|c|c|c|c|c|c|}
\hline \multicolumn{8}{|c|}{ LOJA $150 \mathrm{~m}^{2}$} \\
\hline Cargos & Quantidade & \multicolumn{2}{|c|}{ Salários } & \multicolumn{2}{|c|}{ Encargos } & \multicolumn{2}{|c|}{ Custo total com salários } \\
\hline Diretoria & 1 & $\mathrm{R} \$$ & $6.580,00$ & $\mathrm{R} \$$ & $2.222,07$ & $\mathrm{R} \$$ & $8.802,07$ \\
\hline Conselho Fiscal & 3 & $\mathrm{R} \$$ & $2.500,00$ & $\mathrm{R} \$$ & 844,25 & $\mathrm{R} \$$ & $10.032,75$ \\
\hline Tesoureiro & 1 & $\mathrm{R} \$$ & $2.740,29$ & $\mathrm{R} \$$ & 925,39 & $\mathrm{R} \$$ & $3.665,68$ \\
\hline Gerente de Loja & 1 & $\mathrm{R} \$$ & $4.387,50$ & $\mathrm{R} \$$ & $1.481,66$ & $\mathrm{R} \$$ & $5.869,16$ \\
\hline Líderes de Secção & 3 & $\mathrm{R} \$$ & $3.287,05$ & $\mathrm{R} \$$ & $1.110,04$ & $\mathrm{R} \$$ & $13.191,24$ \\
\hline Repositores & 3 & $\mathrm{R} \$$ & $1.569,28$ & $\mathrm{R} \$$ & 529,95 & $\mathrm{R} \$$ & $6.297,68$ \\
\hline Serviços Gerais & 4 & $\mathrm{R} \$$ & $1.424,60$ & $\mathrm{R} \$$ & 481,09 & $\mathrm{R} \$$ & $7.622,75$ \\
\hline Caixas & 5 & $\mathrm{R} \$$ & $1.463,43$ & $\mathrm{R} \$$ & 494,20 & $\mathrm{R} \$$ & $9.788,12$ \\
\hline \multicolumn{6}{|l|}{ Total } & $\mathrm{R} \$$ & $65.269,44$ \\
\hline
\end{tabular}

Fonte: Elaborado pelo autor.

A loja de $150 \mathrm{~m}^{2}$ tem folha salarial equivalente a $\mathrm{R} \$ 65.269,44$ sessenta e cinco mil duzentos e sessenta e nova reais e quarenta e quatro centavos. O corpo funcional é composto por: uma diretoria, três conselheiros fiscais, um tesoureiro, um gerente de loja, três líderes de secção, três repositores, quatro serviços gerais e cinco caixas.

Tabela 24 - Custo mensal salários supermercado $300 \mathrm{~m}^{2}$

\begin{tabular}{|c|c|c|c|c|c|c|c|}
\hline \multicolumn{8}{|c|}{ SUPERMERCADO 300m² } \\
\hline Cargos & Quantidade & \multicolumn{2}{|c|}{ Salários } & \multicolumn{2}{|c|}{ Encargos } & \multicolumn{2}{|c|}{ Custo total com salários } \\
\hline Diretoria & 1 & $\mathrm{R} \$$ & $6.580,00$ & $\mathrm{R} \$$ & $2.222,07$ & $\mathrm{R} \$$ & $8.802,07$ \\
\hline Conselho Fiscal & 3 & $\mathrm{R} \$$ & $2.500,00$ & $\mathrm{R} \$$ & 844,25 & $\mathrm{R} \$$ & $10.032,75$ \\
\hline Tesoureiro & 1 & $\mathrm{R} \$$ & $2.740,29$ & $\mathrm{R} \$$ & 925,39 & $\mathrm{R} \$$ & $3.665,68$ \\
\hline Gerente de Loja & 1 & $\mathrm{R} \$$ & $4.387,50$ & $\mathrm{R} \$$ & $1.481,66$ & $\mathrm{R} \$$ & $5.869,16$ \\
\hline Líderes de Secção & 5 & $\mathrm{R} \$$ & $3.287,05$ & $\mathrm{R} \$$ & $1.110,04$ & $\mathrm{R} \$$ & $21.985,40$ \\
\hline Repositores & 5 & $\mathrm{R} \$$ & $1.569,28$ & $\mathrm{R} \$$ & 529,95 & $\mathrm{R} \$$ & $10.496,13$ \\
\hline Serviços Gerais & 6 & $\mathrm{R} \$$ & $1.424,60$ & $\mathrm{R} \$$ & 481,09 & $\mathrm{R} \$$ & $11.434,12$ \\
\hline Caixas & 5 & $\mathrm{R} \$$ & $1.463,43$ & $\mathrm{R} \$$ & 494,20 & $\mathrm{R} \$$ & $9.788,12$ \\
\hline \multicolumn{6}{|l|}{ Total } & $\mathrm{R} \$$ & $82.073,43$ \\
\hline
\end{tabular}

Fonte: Elaborado pelo autor.

A loja de $300 \mathrm{~m}^{2}$ tem folha salarial equivalente a $\mathrm{R} \$ 82.073,43$, oitenta e dois mil e setenta e três reais e quarenta e três centavos. Composta por: uma diretoria, três conselheiros fiscais, um tesoureiro, um gerente de loja, cinco líderes de secção, cinco repositores, seis serviços gerais e cinco caixas. 


\subsection{Desconto de mão-de-obra voluntário}

Como a proposta da cooperativa é tornar acessível o produto orgânico a toda população, e a principal vantagem observada para os consumidores de produtos orgânicos participarem de uma cooperativa de produtos orgânicos no Distrito Federal é a relação de preço e desconto, como demonstrado na pesquisa, $86,4 \%$ afirmam que o principal motivo para participarem de uma cooperativa seria o preço/desconto no momento da compra.

Em uma análise financeira uma das possibilidades para se conseguir diminuir o preço para o consumidor final é tentar minimizar os custos por meio da mão-de-obra, neste caso, a cooperativa sugere a possibilidade de os cooperados terem a possibilidade de dedicar parte de seu tempo para desempenhar atividades laborais de forma voluntária.

As tabelas de desconto de mão-de-obra levam em consideração descontos que variam de $20 \%$ até $50 \%$ de custos relacionados a salários e encargos, ou seja, neste trabalho os modelos de cooperativa podem reduzir até $50 \%$ do valor total gasto com mão de obra.

Tabela 25 - Desconto de mão de obra voluntária $30 \mathrm{~m}^{2}$

\begin{tabular}{|c|c|c|c|c|c|c|c|c|c|c|}
\hline \multicolumn{11}{|c|}{ 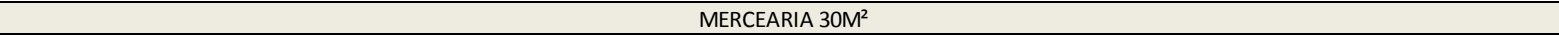 } \\
\hline Descrição & Cust & ensal ( $R \$$ ) & Des & de $20 \% \mathrm{MO}$ & DESC & $\mathrm{TO} 30 \% \mathrm{MO}$ & DESC & $\mathrm{MO}$ & DESC & TO 50\% MO \\
\hline Aluguel & $\mathrm{R} \$$ & $3.478,80$ & $\mathrm{R} \$$ & $3.478,80$ & $\mathrm{RS}$ & $3.478,80$ & $\mathrm{RS}$ & $3.478,80$ & $\mathrm{R} \$$ & $3.478,80$ \\
\hline Condomínio & $\mathrm{R} \$$ & 233,10 & $\mathrm{R} \$$ & 233,10 & $\mathrm{R} \$$ & 233,10 & $\mathrm{RS}$ & 233,10 & $\mathrm{R} \$$ & 233,10 \\
\hline Água & $\mathrm{R} \$$ & 444,00 & $\mathrm{R} \$$ & 444,00 & $\mathrm{R} \$$ & 444,00 & $\mathrm{R} \$$ & 444,00 & $\mathrm{R} \$$ & 444,00 \\
\hline Energia elétrica & $\mathrm{R} \$$ & 229,85 & $\mathrm{R} \$$ & 229,85 & $\mathrm{R} \$$ & 229,85 & $\mathrm{RS}$ & 229,85 & $\mathrm{R} \$$ & 229,85 \\
\hline Telefone + Internet & $\mathrm{R} \$$ & 260,00 & $\mathrm{R} \$$ & 260,00 & $\mathrm{R} \$$ & 260,00 & $\mathrm{RS}$ & 260,00 & $\mathrm{R} \$$ & 260,00 \\
\hline Honorários do contador & $\mathrm{R} \$$ & 800,00 & $\mathrm{R} \$$ & 800,00 & $\mathrm{R} \$$ & 800,00 & $\mathrm{RS}$ & 800,00 & $\mathrm{R} \$$ & 800,00 \\
\hline Manutenção dos equipamentos & $\mathrm{R} \$$ & 400,00 & $\mathrm{R} \$$ & 400,00 & $\mathrm{RS}$ & 400,00 & $\mathrm{RS}$ & 400,00 & $\mathrm{RS}$ & 400,00 \\
\hline Salários + encargos & $\mathrm{R} \$$ & $38.337,10$ & $\mathrm{R} \$$ & $30.669,68$ & $\mathrm{R} \$$ & $26.835,97$ & $\mathrm{R} \$$ & $23.002,26$ & $\mathrm{R} \$$ & $19.168,55$ \\
\hline Material de limpeza & $\mathrm{R} \$$ & 200,00 & $\mathrm{R} \$$ & 200,00 & $\mathrm{R} \$$ & 200,00 & $\mathrm{RS}$ & 200,00 & $\mathrm{R} \$$ & 200,00 \\
\hline Material de escritório & $\mathrm{RS}$ & 150,00 & $\mathrm{R} \$$ & 150,00 & $\mathrm{RS}$ & 150,00 & $\mathrm{RS}$ & 150,00 & $\mathrm{RS}$ & 150,00 \\
\hline Perda & $\mathrm{RS}$ & 250,00 & $\mathrm{R} \$$ & 250,00 & $\mathrm{R} \$$ & 250,00 & $\mathrm{R} \$$ & 250,00 & $\mathrm{R} \$$ & 250,00 \\
\hline Total & $\mathrm{R} \$$ & $44.782,85$ & $\mathrm{R} \$$ & $37.115,43$ & $\mathrm{R} \$$ & $33.281,72$ & $\mathrm{RS}$ & $29.448,01$ & $\mathrm{R} \$$ & $25.614,30$ \\
\hline IPTU & $\mathrm{R} \$$ & 161,00 & $\mathrm{R} \$$ & 161,00 & $\mathrm{RS}$ & 161,00 & $\mathrm{RS}$ & 161,00 & $\mathrm{RS}$ & 161,00 \\
\hline Total + IPTU & $\mathrm{RS}$ & $44.943,85$ & $\mathrm{RS}$ & $37.276,43$ & $\mathrm{RS}$ & $33.442,72$ & $\mathrm{RS}$ & $29.609,01$ & $\mathrm{RS}$ & $25.775,30$ \\
\hline
\end{tabular}

Fonte: Elaborado pelo próprio autor.

Na loja de $30 \mathrm{~m}^{2}$ é possível observar o desconto gradual no valor da mão de obra mensal que apresenta desconto gradativo de $20 \%, 30 \%, 40 \%$ e $50 \%$. No caso da loja de $30 \mathrm{~m}^{2}$ o objetivo é ter apenas o quadro obrigatório por lei para compor os custos relacionados ao salário, ou seja, diretoria e conselho fiscal para manutenção da loja, e redução em $50 \%$ dos custos com gasto de funcionários. Essa redução se dará não só com as obrigações da loja sendo desempenhadas pela diretoria, mas com um conjunto de cooperados voluntários que desempenharão atividades laborais em troca de desconto em seus produtos.

É possível observar a dimensão da economia gerada com o desempenho de atividades laborais voluntárias, o valor de salários e encargos sem nenhum desconto é de $\mathrm{R} \$ 38.337,10$, trinta e oito mil trezentos e trinta e sete reais e dez centavos, e passa a ser $\mathrm{R} \$ 19.168,55$ dezenove mil cento e sessenta e oito reais e cinquenta e cinco centavos de economia mensal. 
Tabela 26 - Desconto de mão de obra voluntária $150 \mathrm{~m}^{2}$

\begin{tabular}{|c|c|c|c|c|c|c|c|c|c|c|}
\hline \multicolumn{11}{|c|}{ MERCEARIA $150 \mathrm{M}^{2}$} \\
\hline \multirow[t]{2}{*}{ Descrição } & \multicolumn{2}{|c|}{ Custo total mensal (R\$) } & \multicolumn{2}{|c|}{ Desconto de $20 \%$ MO } & \multicolumn{2}{|c|}{ DESCONTO $30 \%$ MO } & \multicolumn{2}{|c|}{ DESCONTO 40\% MO } & \multicolumn{2}{|c|}{ DESCONTO 50\% MO } \\
\hline & $R \$$ & $17.394,00$ & $R \$$ & $17.394,00$ & $R \$$ & $17.394,00$ & $R \$$ & $17.394,00$ & $\mathrm{R} \$$ & $17.394,00$ \\
\hline Condomínio & $\mathrm{R} \$$ & $1.165,50$ & $\mathrm{R} \$$ & $1.165,50$ & $R \$$ & $1.165,50$ & $\mathrm{R} \$$ & $1.165,50$ & $\mathrm{R} \$$ & $1.165,50$ \\
\hline Água & $\mathrm{R} \$$ & 444,00 & $\mathrm{R} \$$ & 444,00 & $\mathrm{R} \$$ & 444,00 & $\mathrm{R} \$$ & 444,00 & $\mathrm{R} \$$ & 444,00 \\
\hline Energia elétrica & $\mathrm{R} \$$ & 591,35 & $\mathrm{R} \$$ & 591,35 & $\mathrm{R} \$$ & 591,35 & $\mathrm{R} \$$ & 591,35 & $\mathrm{R} \$$ & 591,35 \\
\hline Telefone + Internet & $\mathrm{R} \$$ & 260,00 & $\mathrm{R} \$$ & 260,00 & $\mathrm{R} \$$ & 260,00 & $\mathrm{R} \$$ & 260,00 & $\mathrm{R} \$$ & 260,00 \\
\hline Honorários do contador & $\mathrm{R} \$$ & 800,00 & $\mathrm{R} \$$ & 800,00 & $\mathrm{R} \$$ & 800,00 & $\mathrm{R} \$$ & 800,00 & $\mathrm{R} \$$ & 800,00 \\
\hline Manutenção dos equipamentos & $\mathrm{R} \$$ & 400,00 & $\mathrm{R} \$$ & 400,00 & $\mathrm{R} \$$ & 400,00 & $\mathrm{R} \$$ & 400,00 & $\mathrm{R} \$$ & 400,00 \\
\hline Salários + encargos & $\mathrm{R} \$$ & $65.269,44$ & $\mathrm{RS}$ & $52.215,55$ & $\mathrm{RS}$ & $45.688,61$ & $\mathrm{RS}$ & $39.161,66$ & $\mathrm{R} \$$ & $32.634,72$ \\
\hline Material de limpeza & $\mathrm{R} \$$ & 400,00 & $\mathrm{R} \$$ & 400,00 & $\mathrm{R} \$$ & 400,00 & $\mathrm{R} \$$ & 400,00 & $\mathrm{R} \$$ & 400,00 \\
\hline Material de escritório & $\mathrm{R} \$$ & 250,00 & $\mathrm{R} \$$ & 250,00 & $\mathrm{R} \$$ & 250,00 & $\mathrm{R} \$$ & 250,00 & $\mathrm{R} \$$ & 250,00 \\
\hline Perda & $\mathrm{R} \$$ & 400,00 & $\mathrm{R} \$$ & 400,00 & $\mathrm{R} \$$ & 400,00 & $\mathrm{R} \$$ & 400,00 & $\mathrm{R} \$$ & 400,00 \\
\hline Total & $\mathrm{R} \$$ & $87.374,29$ & $\mathrm{R} \$$ & $74.320,40$ & $\mathrm{R} \$$ & $67.793,46$ & $\mathrm{R} \$$ & $61.266,51$ & $\mathrm{R} \$$ & $54.739,57$ \\
\hline IPTU & $\mathrm{R} \$$ & 805,00 & $\mathrm{R} \$$ & 805,00 & $R \$$ & 805,00 & $\mathrm{R} \$$ & 805,00 & $\mathrm{R} \$$ & 805,00 \\
\hline Total + IPTU & & $175.553,58$ & $\mathbf{R S}$ & $149.445,80$ & $\mathbf{R} \$$ & $136.391,92$ & R\$ & $123.338,03$ & R\$ & $110.284,14$ \\
\hline
\end{tabular}

Fonte: Elaborado pelo próprio autor.

Em uma loja de $150 \mathrm{~m}^{2}$ é possível observar que a mão de obra representa $37 \%$ de todos os custos mensais da cooperativa. Com a possibilidade de mão de obra voluntária isso pode-se reduzir a $29 \%$ dos custos mensais, ou seja, uma economia de $8 \%$ que poderá ser convertida no valor final do alimento orgânico. É possível observar que os custos com mão de obra podem diminuir em até $\mathrm{R} \$ 32.634,72$ mensais.

Tabela 27 - Desconto de mão de obra voluntária 300m².

\begin{tabular}{|c|c|c|c|c|c|c|c|c|c|c|}
\hline \multicolumn{11}{|c|}{ MERCEARIA $300 \mathrm{~m}^{2}$} \\
\hline \multirow[t]{2}{*}{ Descrição } & \multicolumn{2}{|c|}{ Custo total mensal (R\$) } & \multicolumn{2}{|c|}{ Desconto de $20 \%$ MO } & \multicolumn{2}{|c|}{ DESCONTO $30 \%$ MO } & \multicolumn{2}{|c|}{ DESCONTO $40 \%$ MO } & \multicolumn{2}{|c|}{ DESCONTO 50\% MO } \\
\hline & $\mathrm{R} \$$ & $34.788,00$ & $\mathrm{R} \$$ & $34.788,00$ & $\mathrm{R} \$$ & $34.788,00$ & $\mathrm{R} \$$ & $34.788,00$ & $\mathrm{R} \$$ & $34.788,00$ \\
\hline Condomínio & $\mathrm{R} \$$ & $2.331,00$ & $\mathrm{R} \$$ & $2.331,00$ & $\mathrm{R} \$$ & $2.331,00$ & $\mathrm{R} \$$ & $2.331,00$ & $\mathrm{R} \$$ & $2.331,00$ \\
\hline Água & $\mathrm{R} \$$ & $1.000,00$ & $\mathrm{R} \$$ & $1.000,00$ & $\mathrm{R} \$$ & $1.000,00$ & $\mathrm{R} \$$ & $1.000,00$ & $\mathrm{R} \$$ & $1.000,00$ \\
\hline Energia elétrica & $\mathrm{R} \$$ & $1.083,71$ & $\mathrm{R} \$$ & $1.083,71$ & $\mathrm{R} \$$ & $1.083,71$ & $\mathrm{R} \$$ & $1.083,71$ & $\mathrm{R} \$$ & $1.083,71$ \\
\hline Telefone + Internet & $\mathrm{R} \$$ & 260,00 & $\mathrm{R} \$$ & 260,00 & $R \$$ & 260,00 & $\mathrm{R} \$$ & 260,00 & $R \$$ & 260,00 \\
\hline Honorários do contador & $\mathrm{R} \$$ & 800,00 & $\mathrm{R} \$$ & 800,00 & $\mathrm{R} \$$ & 800,00 & $\mathrm{R} \$$ & 800,00 & $\mathrm{R} \$$ & 800,00 \\
\hline Manutenção dos equipamentos & $\mathrm{R} \$$ & 400,00 & $\mathrm{R} \$$ & 400,00 & $\mathrm{R} \$$ & 400,00 & $\mathrm{R} \$$ & 400,00 & $\mathrm{R} \$$ & 400,00 \\
\hline Salários + encargos & $\mathrm{R} \$$ & $82.073,43$ & $\mathrm{RS}$ & $65.658,74$ & $\mathrm{RS}$ & $57.451,40$ & $\mathrm{RS}$ & $49.244,06$ & $\mathrm{RS}$ & $41.036,71$ \\
\hline Material de limpeza & $\mathrm{R} \$$ & 400,00 & $\mathrm{R} \$$ & 400,00 & $\mathrm{R} \$$ & 400,00 & $\mathrm{R} \$$ & 400,00 & $\mathrm{R} \$$ & 400,00 \\
\hline Material de escritório & $\mathrm{R} \$$ & 300,00 & $\mathrm{R} \$$ & 300,00 & $\mathrm{R} \$$ & 300,00 & $\mathrm{R} \$$ & 300,00 & $\mathrm{R} \$$ & 300,00 \\
\hline Perda & $\mathrm{R} \$$ & 250,00 & $\mathrm{R} \$$ & 250,00 & $\mathrm{R} \$$ & 250,00 & $\mathrm{R} \$$ & 250,00 & $\mathrm{R} \$$ & 250,00 \\
\hline Total & $\mathrm{R} \$$ & $123.686,14$ & $\mathrm{R} \$$ & $107.271,45$ & $\mathrm{R} \$$ & $99.064,11$ & $\mathrm{R} \$$ & $90.856,77$ & $\mathrm{R} \$$ & $82.649,42$ \\
\hline IPTU & $\mathrm{R} \$$ & $1.610,00$ & $\mathrm{R} \$$ & $1.610,00$ & $\mathrm{R} \$$ & $1.610,00$ & $\mathrm{R} \$$ & $1.610,00$ & $\mathrm{R} \$$ & $1.610,00$ \\
\hline Total + IPTU & & $248.982,27$ & $\mathbf{R S}$ & $216.152,90$ & $\mathbf{R S}$ & $199.738,22$ & R\$ & $183.323,53$ & $\mathbf{R S}$ & $166.908,85$ \\
\hline
\end{tabular}

Fonte: Elaborado pelo próprio autor.

Na loja de $300 \mathrm{~m}^{2}$ o custo total sem trabalho voluntário é equivalente a $32 \%$ de todos os custos mensais da cooperativa. Com o desconto gradual esse custo passa a ser o equivalente a $24 \%$ do valor dos custos totais da cooperativa. Podendo este a economizar até R\$ 41.036,71 (quarenta e um mil e trinta e seis reais e setenta e um centavos) de custos mensais, que poderão ser convertidos em benfeitorias aos cooperados.

\subsubsection{Estimativa de faturamento}

Para determinação de uma estimativa de faturamento foi necessário a divisão da loja em áreas de venda. As áreas de venda geralmente presentes no autosserviço brasileiro são FLV (Frutas, legumes e verduras), padaria, açougue, peixaria, área líquida, higiene e limpeza e bazar. As tabelas de estimativa de faturamento foram divididas em três modelos de loja, sendo $30 \mathrm{~m}^{2}$, 
$150 \mathrm{~m}^{2}, 300 \mathrm{~m}^{2}$, cada tabela apresenta as áreas de venda, o valor percentual da correspondência de venda, ou seja, o quanto se espera que cada área venda, o valor proporcional a receita, a margem de contribuição e o valor ponderado da receita com a margem de contribuição.

É possível observar que a margem de contribuição cobrada pela cooperativa oferece vantagens aos seus cooperados em relação ao preço. Neste estudo, a cooperativa sugere uma margem de contribuição que varia entre $20 \% 40 \%$ acima do valor de nota fiscal. Os percentuais foram definidos a partir do fluxo de compra de cada produto, ou seja, quanto maior o fluxo daquele produto, maior a demanda e por conseguinte maior o valor do desconto. Isso pode ser observado quando se compara áreas que vendem frutas, legumes e verduras, que são produtos de alto giro e procura diária, e margem de contribuição de apenas $20 \%$ sobre o valor de nota fiscal, e produtos do bazar que são vendidos em quantidades menores, com menor frequência e correspondem a uma maior margem de contribuição, $40 \%$ sobre o valor de compra.

São margens de contribuição abaixo da prática de mercado, que variam entre $35 \%$ para produtos de alto giro e até a $250 \%$ para produtos de menor giro como por exemplo produtos do bazar. Esses valores são sugestões para uma estimativa de venda, no momento de implantação da cooperativa faz-se um acompanhamento mensal do faturamento, com a possibilidade de ajuste destes valores.

Tabela 28 - Estimativa de faturamento $30 \mathrm{~m}^{2}$.

\begin{tabular}{|c|c|c|c|c|c|c|}
\hline \multicolumn{7}{|c|}{ ESTIMATIVA DE VENDA MERCEARIA 30M ${ }^{2}$} \\
\hline Áreas & Correspondência & & Receita & Margem de contribuição & & derada \\
\hline FLV & $60 \%$ & $\mathrm{R} \$$ & $60.000,00$ & $20 \%$ & $\mathrm{R} \$$ & $72.000,00$ \\
\hline Padaria & $15 \%$ & $\mathrm{R} \$$ & $15.000,00$ & $20 \%$ & $\mathrm{R} \$$ & $18.000,00$ \\
\hline Açougue & $0 \%$ & $\mathrm{R} \$$ & - & $20 \%$ & $\mathrm{R} \$$ & - \\
\hline Peixaria & $0 \%$ & $\mathrm{R} \$$ & - & $20 \%$ & $\mathrm{R} \$$ & - \\
\hline Líquida & $15 \%$ & $\mathrm{R} \$$ & $15.000,00$ & $20 \%$ & $\mathrm{R} \$$ & $18.000,00$ \\
\hline Higiêne e Limpeza & $7 \%$ & $\mathrm{R} \$$ & $7.000,00$ & $40 \%$ & $\mathrm{R} \$$ & $9.800,00$ \\
\hline Bazar & $3 \%$ & $\mathrm{R} \$$ & $3.000,00$ & $40 \%$ & $\mathrm{R} \$$ & $4.200,00$ \\
\hline \multicolumn{5}{|c|}{ FATURAMENTO TOTAL } & $\mathrm{R} \$$ & $122.000,00$ \\
\hline
\end{tabular}

Fonte: Elaborado pelo próprio autor.

A Tabela 28 demonstra a estimativa de faturamento de uma loja de 30 metros quadrados. Para esta análise, leva-se em consideração as áreas: frutas, legumes e verduras, padaria, líquida, higiene e limpeza e bazar, não há espaço suficiente para ofertar uma estrutura de açougue e peixaria. Espera-se que as áreas tenham a seguinte correspondência de vendas: FLV (60\%) equivalente a $\mathrm{R} \$ 72.000,00$ da receita total da loja, a padaria e líquida (15\%) equivalente a $\mathrm{R} \$ 18.000,00$ da receita total da loja, higiene e limpeza (7\%) equivalente a $\mathrm{R} \$ 9.800,00$ da receita total da loja e o bazar (3\%) equivalente a $\mathrm{R} \$ 4.200,00$ da receita total da loja. Em uma condição ideal de vendas, considerando a venda total do estoque desprezando perdas, a loja teria um faturamento de $\mathrm{R} \$ 122.000,00$ cento e vinte e dois mil reais. 
Tabela 29 - Estimativa de faturamento $150 \mathrm{~m}^{2}$.

\begin{tabular}{|c|c|c|c|c|c|c|}
\hline \multicolumn{7}{|c|}{ Estimativa $150 \mathrm{~m}^{2}$} \\
\hline Áreas & Correspondência & & al Receita & Margem de contribuição & & derada \\
\hline FLV & $50 \%$ & $\mathrm{R} \$$ & $125.000,00$ & $20 \%$ & $\mathrm{R} \$$ & $150.000,00$ \\
\hline Padaria & $15 \%$ & $\mathrm{R} \$$ & $37.500,00$ & $20 \%$ & $\mathrm{R} \$$ & $45.000,00$ \\
\hline Açougue & $10 \%$ & $\mathrm{RS}$ & $25.000,00$ & $20 \%$ & $\mathrm{R} \$$ & $30.000,00$ \\
\hline Peixaria & $0 \%$ & $\mathrm{R} \$$ & - & $20 \%$ & $\mathrm{R} \$$ & - \\
\hline Líquida & $15 \%$ & $\mathrm{R} \$$ & $37.500,00$ & $20 \%$ & $\mathrm{R} \$$ & $45.000,00$ \\
\hline Higiêne e Limpeza & $7 \%$ & $\mathrm{RS}$ & $17.500,00$ & $40 \%$ & $\mathrm{R} \$$ & $24.500,00$ \\
\hline Bazar & $3 \%$ & $\mathrm{R} \$$ & $7.500,00$ & $40 \%$ & $\mathrm{R} \$$ & $10.500,00$ \\
\hline \multicolumn{5}{|c|}{ FATURAMENTO TOTAL } & $\mathrm{R} \$$ & $305.000,00$ \\
\hline
\end{tabular}

Fonte: Elaborado pelo próprio autor.

Em uma loja de $150 \mathrm{~m}^{2}$ a estimativa de faturamento, em uma condição ideal demonstrada na Tabela 29, é de $\mathrm{R} \$ 305.000,00$ trezentos e cinco mil reais, divididos em FLV (50\%) equivalente a $\mathrm{R} \$ 125.000,00$; Padaria e Líquida (15\%) equivalente a $\mathrm{R} \$ 37.500,00$; Açougue (10\%) equivalente a $\mathrm{R} \$ 25.000,00$; Higiêne e limpeza (7\%) R\$17.500,00; Bazar (3\%) equivalente a $\mathrm{R} \$ 7.500,00$. Em virtude do tamanho da loja a peixaria não fará parte da loja.

Tabela 30 - Estimativa de faturamento $300 \mathrm{~m}^{2}$.

\begin{tabular}{|c|c|c|c|c|c|c|}
\hline \multicolumn{7}{|c|}{ Estimativa $300 \mathrm{~m}^{2}$} \\
\hline Áreas & Correspondência & & al Receita & Margem de contribuição & & derada \\
\hline FLV & $45 \%$ & $\mathrm{R} \$$ & $180.000,00$ & $20 \%$ & $\mathrm{R} \$$ & $216.000,00$ \\
\hline Padaria & $15 \%$ & $\mathrm{R} \$$ & $60.000,00$ & $20 \%$ & $\mathrm{R} \$$ & $72.000,00$ \\
\hline Açougue & $15 \%$ & $\mathrm{R} \$$ & $60.000,00$ & $20 \%$ & $\mathrm{RS}$ & $72.000,00$ \\
\hline Peixaria & $7 \%$ & $\mathrm{R} \$$ & $28.000,00$ & $20 \%$ & $\mathrm{R} \$$ & $33.600,00$ \\
\hline Líquida & $10 \%$ & $\mathrm{R} \$$ & $40.000,00$ & $20 \%$ & $\mathrm{R} \$$ & $48.000,00$ \\
\hline Higiêne e Limpeza & $5 \%$ & $\mathrm{R} \$$ & $20.000,00$ & $40 \%$ & $\mathrm{R} \$$ & $28.000,00$ \\
\hline Bazar & $3 \%$ & $\mathrm{R} \$$ & $12.000,00$ & $40 \%$ & $\mathrm{R} \$$ & $16.800,00$ \\
\hline \multicolumn{5}{|c|}{ FATURAMENTO TOTAL } & $\mathrm{R} \$$ & $486.400,00$ \\
\hline
\end{tabular}

Fonte: Elaborado pelo próprio autor.

1. Contribuição cotistas

$\mathrm{Na}$ loja de $300 \mathrm{~m}^{2}$ é possível, em condição ideal de venda, o faturamento possível é de até $\mathrm{R} \$ 486.400,00$ quatrocentos e oitenta e seis mil e quatrocentos reais, distribuídos em FLV (45\%) R \$ 180.000,00; Padaria e Açougue (15\%) R \$60.000,00; Peixaria (7\%) R \$ 28.000,00; Líquida $(10 \%) \mathrm{R} \$ 40.000,00 ;$ Higiene e limpeza (5\%) R \$ 20.000,00; Bazar (3\%) R\$12.000,00.

\subsubsection{Análise e distribuição de cotas}

Para determinar o número de cotas necessárias para compor a cooperativa em uma situação de vendas que abrange o investimento inicial e o número de cotistas fez-se necessário algumas projeções de vendas juntamente com o rateio entre os associados. As tabelas abaixo demonstram o valor do investimento inicial e as projeções de venda ao longo dos meses. Essas projeções são feitas até o momento em que os valores das cotas não são mais custeados pelos cooperados, ou seja, chega-se a um ponto em que todo o investimento feito para criação da cooperativa é subsidiado com as próprias vendas. 
Tabela 31 - Divisão de cotas 30m².

\begin{tabular}{|c|c|c|c|c|c|c|c|c|c|c|c|c|c|c|}
\hline \multicolumn{15}{|c|}{ MERCEARIA $30 \mathrm{~m}^{2}$} \\
\hline Número de Sócios & \multicolumn{2}{|c|}{$\begin{array}{l}\text { Investimento } \\
\text { Inicial }\end{array}$} & \multicolumn{2}{|c|}{$\begin{array}{c}\text { 19 PERÍODO } \\
\text { (40\% VENDA) }\end{array}$} & \multicolumn{2}{|c|}{$\begin{array}{l}\text { 20 PERÍODO } \\
\text { (50\% Venda) }\end{array}$} & \multicolumn{2}{|c|}{$\begin{array}{l}\text { 3o PERÍODO } \\
\text { (60\% venda) }\end{array}$} & \multicolumn{2}{|c|}{$\begin{array}{l}\text { 4\% PERÍODO } \\
\text { (70\% venda) }\end{array}$} & \multicolumn{2}{|c|}{$\begin{array}{l}\text { 5o PERÍODO } \\
\text { (80\% venda) }\end{array}$} & \multicolumn{2}{|c|}{$\begin{array}{l}\text { 60 PERÍODO } \\
\text { (90\% venda) }\end{array}$} \\
\hline Valor da Cooperativa & $\mathrm{RS}$ & $178.102,08$ & $\mathrm{R} \$$ & $88.716,43$ & $\mathrm{RS}$ & $12.242,72$ & $\mathrm{RS}$ & $5.769,01$ & $-\mathrm{RS}$ & 704,70 & & $3.344,70$ & $-\mathrm{R} \$$ & $5.984,70$ \\
\hline Número mínimo de Sócios 20 & $\mathrm{RS}$ & $8.905,10$ & $\mathrm{R} \$$ & $4.435,82$ & $\mathrm{R} \$$ & 612,14 & $\mathrm{R} \$$ & 288,45 & $-R \$$ & 35,23 & $-R \$$ & 167,23 & $-R \$$ & 299,23 \\
\hline Número de Sócios 30 & $\mathrm{RS}$ & $5.936,74$ & $\mathrm{R} \$$ & $2.957,21$ & $\mathrm{RS}$ & 408,09 & $\mathrm{RS}$ & 192,30 & $-R \$$ & 23,49 & $-R \$$ & 111,49 & $-R \$$ & 199,49 \\
\hline Número de Sócios 40 & $\mathrm{RS}$ & $4.452,55$ & $\mathrm{RS}$ & $2.217,91$ & $\mathrm{RS}$ & 306,07 & $\mathrm{RS}$ & 144,23 & $-R \$$ & 17,62 & $-R \$$ & 83,62 & $-R S$ & 149,62 \\
\hline Número de Sócios 50 & $\mathrm{RS}$ & $3.562,04$ & $\mathrm{RS}$ & $1.774,33$ & $\mathrm{RS}$ & 244,85 & $\mathrm{R} \$$ & 115,38 & $-R \$$ & 14,09 & $-R \$$ & 66,89 & $-R \$$ & 119,69 \\
\hline
\end{tabular}

Fonte: Elaborado pelo próprio autor.

A Tabela 31 simula os valores das cotas de acordo com o número de participantes e o percentual de vendas da cooperativa. $O$ investimento inicial da cooperativa de $30 \mathrm{~m}^{2}$ é de 178.102,00. Para as simulações que envolvem número de cotistas leva-se em consideração o Artigo $6^{\circ}$, presente no Apêndice $\mathrm{O}$, que determina no mínimo 20 cooperados para oficialização de uma cooperativa.

Sendo assim na primeira coluna é possível observar o rateio do investimento inicial em cotas. Com 20 sócios de cada cota é R \$ 8.905,10; com trinta sócios o investimento inicial dos cotistas passa a ser de $\mathrm{R} \$ 5.936,74$; com quarenta sócios $\mathrm{R}$ \$4.452,55; com cinquenta sócios $\mathrm{R} \$$ 3562,04 .

A partir da abertura da cooperativa e por consequência suas vendas, no primeiro mês estipulou-se que a cooperativa apresentaria valor de venda igual a $40 \%$ de todo seu estoque, aplicado a margem de contribuição em função do valor total de arrecadação. Aplica-se nesse caso um desconto de $20 \%$ relacionado a mão de obra voluntária no primeiro mês, onde já é possível minimizar os custos operacionais. As cotas passam a custar no primeiro mês para o valor individual de $\mathrm{R} \$ 4.435,82$ para 30 sócios $\mathrm{R} \$ 2.957,21 ; 40$ sócios $\mathrm{R} \$ 2.217,91 ; 50$ sócios $1.774,33,53$.

No segundo período vendas leva-se em consideração que a loja irá vender realizar a recompra de $40 \%$ daquilo que foi vendido no primeiro mês para compor seu estoque de loja, e irá vender $50 \%$ de seus produtos. Com a venda de $50 \%$ de toda a loja, juntamente com os custos fixos é possível observar que a cooperativa tem valor estimado em $\mathrm{R} \$ 12.242,72$. Os valores das cotas distribuídas neste período são equivalentes a: 20 sócios - R \$ 612,14; 30 sócios - R \$ 408,09; 40 sócios - $\mathrm{R}$ \$ 306,07; 50 sócios $\mathrm{R}$ 244, 85.

O terceiro período os sócios ainda terão que fazer investimentos para manter a cooperativa. Mesmo vendendo 60\% de todo o estoque presente na loja, juntamente com uma margem de contribuição de $20 \%$.

O quarto, quinto e sexto período com respectivamente $70 \%, 80 \%$ e $90 \%$ das vendas a cooperativa se mostra superavitária, com rendimentos que poderão ser reinvestidos na cooperativa, como forma de divulgação, ampliação da loja, aquisição de novos equipamentos 
ou contratação de pessoas. O retorno da cooperativa varia de $\mathrm{R} \$ 704,70$ até $\mathrm{R} \$ 5.984,70$. Caso esse valor fosse distribuído em cotas cada cota iria variar de $\mathrm{R} \$ 14,09$, até $\mathrm{R} \$ 35,23$ a com 70\% das vendas; $R$ \$ 66,89 a 167,23 com 80\% das vendas; $R$ \$ 119,69 a 299,23 com 90\% das vendas. Tabela 32 - Divisão de cotas $150 \mathrm{~m}^{2}$.

\begin{tabular}{|c|c|c|c|c|c|c|c|c|c|c|c|c|c|c|c|c|}
\hline \multicolumn{17}{|c|}{ SUPERMERCADO $150 \mathrm{M}^{2}$} \\
\hline \multirow{2}{*}{\begin{tabular}{|c} 
Número de Sócios \\
Valor da Cooperativa
\end{tabular}} & \multicolumn{2}{|c|}{ Investimento Inicial } & \multicolumn{2}{|c|}{\begin{tabular}{|c|} 
19 PERÍODO \\
(40\% VENDA)
\end{tabular}} & \multicolumn{2}{|c|}{$\begin{array}{l}\text { 20 PERÍODO } \\
\text { (50\% Venda) }\end{array}$} & \multicolumn{2}{|c|}{$\begin{array}{l}\text { 30 PERÍODO } \\
\text { (60\% venda) }\end{array}$} & \multicolumn{2}{|c|}{$\begin{array}{l}\text { 4o PERÍODO } \\
\text { (70\% venda) }\end{array}$} & \multicolumn{2}{|c|}{$\begin{array}{c}\text { 5o PERÍODO (80\% } \\
\text { venda) }\end{array}$} & \multicolumn{2}{|c|}{$\begin{array}{l}\text { 60 PERÍODO (90\% } \\
\text { venda) }\end{array}$} & \multicolumn{2}{|c|}{$\begin{array}{l}\text { 70 PERÍODO } \\
\text { (90\% venda) }\end{array}$} \\
\hline & $\mathrm{R} \$$ & $572.053,73$ & $\mathrm{R} \$$ & $28.145,80$ & $\mathrm{R} \$$ & $82.266,92$ & $\mathrm{RS}$ & $61.388,03$ & $\mathrm{RS}$ & $40.509,14$ & $\mathrm{RS}$ & $32.684,14$ & $\mathrm{RS}$ & $11.805,25$ & $-R \$$ & $1.248,64$ \\
\hline Número mínimo de Sócios 20 & $\mathrm{R} \$$ & $28.602,69$ & $\mathrm{R} \$$ & $1.407,29$ & $\mathrm{R} \$$ & $4.113,35$ & $\mathrm{RS}$ & $3.069,40$ & $\mathrm{R} \$$ & $2.025,46$ & $\mathrm{RS}$ & $1.634,21$ & $\mathrm{RS}$ & 590,26 & $-R \$$ & 62,43 \\
\hline Número de Sócios 30 & $\mathrm{RS}$ & $19.068,46$ & $\mathrm{RS}$ & 469,10 & $\mathrm{R} \$$ & $1.371,12$ & $\mathrm{RS}$ & $2.046,27$ & $\mathrm{R} \$$ & $1.350,30$ & $\mathrm{RS}$ & $1.089,47$ & $\mathrm{RS}$ & 93,51 & $-R S$ & 41,62 \\
\hline Número de Sócios 40 & $\mathrm{RS}$ & $14.301,34$ & $\mathrm{RS}$ & 703,65 & $\mathrm{R} \$$ & $2.056,67$ & $\mathrm{RS}$ & $1.534,70$ & $\mathrm{RS}$ & $1.012,73$ & $\mathrm{R} \$$ & 817,10 & $\mathrm{RS}$ & 295,13 & $-R \$$ & 31,22 \\
\hline Número de Sócios 50 & $\mathrm{RS}$ & $11.441,07$ & $\mathrm{RS}$ & 562,92 & $\mathrm{RS}$ & $1.645,34$ & $\mathrm{RS}$ & $1.227,76$ & $\mathrm{RS}$ & 810,18 & $\mathrm{RS}$ & 53,68 & $\mathrm{RS}$ & 236,11 & $-R S$ & 24,97 \\
\hline Número de Sócios 100 & $\mathrm{RS}$ & 20,54 & $\mathrm{RS}$ & 281,46 & $\mathrm{RS}$ & 822,67 & $\mathrm{RS}$ & 613,88 & $\mathrm{RS}$ & 405,09 & $\mathrm{RS}$ & 326,84 & $\mathrm{RS}$ & 118,05 & $-R S$ & 12,49 \\
\hline Número de Sócios 150 & $\mathrm{R} \$$ & $3.813,69$ & $\mathrm{RS}$ & 187,64 & $\mathrm{R} \$$ & 48,45 & $\mathrm{R} \$$ & 409,25 & $\mathrm{R} \$$ & 270,06 & $\mathrm{R} \$$ & 217,89 & $\mathrm{R} \$$ & 78,70 & $-R \$$ & 8,32 \\
\hline Número de Sócios 200 & $\mathrm{RS}$ & $2.860,27$ & $\mathrm{R} \$$ & 140,73 & $\mathrm{R} \$$ & 411,33 & $\mathrm{RS}$ & 306,94 & $\mathrm{R} \$$ & 202,55 & $\mathrm{RS}$ & 163,42 & $\mathrm{RS}$ & 59,03 & $-R \$$ & 6,24 \\
\hline Número de Sócios 300 & $\mathrm{RS}$ & $1.906,85$ & $\mathrm{RS}$ & 93,82 & $\mathrm{R} \$$ & 274,22 & $\mathrm{RS}$ & 204,63 & $\mathrm{RS}$ & 135,03 & $\mathrm{RS}$ & 108,95 & $\mathrm{RS}$ & 39,35 & $-\mathrm{RS}$ & 4,16 \\
\hline Número de Sócios 500 & $\mathrm{RS}$ & $1.144,11$ & $\mathrm{RS}$ & 56,29 & $\mathrm{RS}$ & 164,53 & $\mathrm{RS}$ & 122,78 & $\mathrm{RS}$ & 81,02 & $\mathrm{RS}$ & 65,37 & $\mathrm{RS}$ & 23,61 & $-\mathrm{R} \$$ & 2,50 \\
\hline
\end{tabular}

Fonte: Elaborado pelo próprio autor.

Na simulação do supermercado com $150 \mathrm{~m}^{2}$ o valor total da cooperativa é de $\mathrm{R} \$ 572.053,73$. A distribuição das cotas foi feita em 7 períodos divididos em percentuais de venda, onde o primeiro período vende-se $40 \%$ e o último período vende-se $90 \%$ dos produtos disponíveis na loja. Os cálculos levam em consideração todos os custos envolvidos na loja, e as cotas variam entre 20 e 500 sócios. Os valores das cotas variam entre $R \$ 28,602$, 69 e 23,61 como contribuição. O último período a loja é possível observar o equilíbrio entre os gastos e o possível ganho da cooperativa, a cooperativa se torna superavitária, com a possibilidade de investimentos e benfeitorias para a cooperativa.

Tabela 33 - Divisão de cotas $300 \mathrm{~m}^{2}$.

\begin{tabular}{|c|c|c|c|c|c|c|c|c|c|c|c|c|c|c|}
\hline \multicolumn{15}{|c|}{ SUPERMERCADO $300 \mathrm{~m}^{2}$} \\
\hline \multirow{2}{*}{$\begin{array}{l}\text { Número de Sócios } \\
\text { Valor da Cooperativa }\end{array}$} & \multicolumn{2}{|c|}{ Investimento Inicial } & \multicolumn{2}{|c|}{$\begin{array}{c}\text { 10 PERÍODO } \\
\text { (40\% VENDA) }\end{array}$} & \multicolumn{2}{|c|}{\begin{tabular}{|c|} 
2o PERÍODO \\
(50\% Venda)
\end{tabular}} & \multicolumn{2}{|c|}{$\begin{array}{l}\text { 3o PERÍODO } \\
\text { (60\% venda) }\end{array}$} & \multicolumn{2}{|c|}{$\begin{array}{l}\text { 40 PERÍODO } \\
\text { (70\% venda) } \\
\end{array}$} & \multicolumn{2}{|c|}{$\begin{array}{c}\text { 5o PERÍODO ( } 80 \% \\
\text { venda) }\end{array}$} & \multicolumn{2}{|c|}{$\begin{array}{l}\text { 6o PERÍODO } \\
\text { (90\% venda) }\end{array}$} \\
\hline & $\mathrm{RS}$ & $848.839,42$ & $\mathrm{R} \$$ & $184.680,90$ & & $.57 .898,22$ & $\mathrm{R} \$$ & $131.115,53$ & $\mathrm{R} \$ 1$ & $04.332,85$ & $\mathrm{RS}$ & $93.964,85$ & $\mathrm{RS}$ & $27.182,16$ \\
\hline Número mínimo de Sócios 20 & $\mathrm{RS}$ & $42.441,97$ & $\mathrm{R} \$$ & $9.234,05$ & $\mathrm{R} \$$ & $7.894,91$ & $\mathrm{R} \$$ & $6.555,78$ & $\mathrm{RS}$ & $5.216,64$ & $\mathrm{R} \$$ & $4.698,24$ & $\mathrm{RS}$ & $1.359,11$ \\
\hline Número de Sócios 30 & $\mathrm{RS}$ & $28.294,65$ & $\mathrm{R} \$$ & $3.078,02$ & $\mathrm{RS}$ & $2.631,64$ & $\mathrm{R} \$$ & $4.370,52$ & $\mathrm{RS}$ & $3.477,76$ & $\mathrm{R} \$$ & $3.132,16$ & $\mathrm{RS}$ & 906,07 \\
\hline Número de Sócios 40 & $\mathrm{RS}$ & $21.220,99$ & $\mathrm{R} \$$ & $4.617,02$ & $\mathrm{R} \$$ & $3.947,46$ & $\mathrm{R} \$$ & $3.277,89$ & $\mathrm{R} \$$ & $2.608,32$ & $\mathrm{R} \$$ & $2.349,12$ & $\mathrm{RS}$ & 679,55 \\
\hline Número de Sócios 50 & $\mathrm{RS}$ & $16.976,79$ & $\mathrm{R} \$$ & $3.693,62$ & $\mathrm{R} \$$ & $3.157,96$ & $\mathrm{R} \$$ & $2.622,31$ & $\mathrm{RS}$ & $2.086,66$ & $\mathrm{R} \$$ & $1.879,30$ & $\mathrm{RS}$ & 543,64 \\
\hline Número de Sócios 100 & $\mathrm{RS}$ & $8.488,39$ & $\mathrm{R} \$$ & $1.846,81$ & $\mathrm{R} \$$ & $1.578,98$ & $\mathrm{R} \$$ & $1.311,16$ & $\mathrm{RS}$ & $1.043,33$ & $\mathrm{R} \$$ & 939,65 & $\mathrm{RS}$ & 271,82 \\
\hline Número de Sócios 150 & $\mathrm{R} \$$ & $5.658,93$ & $\mathrm{R} \$$ & $1.231,21$ & $\mathrm{R} \$$ & $1.052,65$ & $\mathrm{R} \$$ & 874,10 & $\mathrm{R} \$$ & 695,55 & $\mathrm{R} \$$ & 626,43 & $\mathrm{RS}$ & 181,21 \\
\hline Número de Sócios 200 & $\mathrm{RS}$ & $4.244,20$ & $\mathrm{R} \$$ & 923,40 & $\mathrm{RS}$ & 789,49 & $\mathrm{R} \$$ & 655,58 & $\mathrm{RS}$ & 521,66 & $\mathrm{RS}$ & 469,82 & $\mathrm{RS}$ & 135,91 \\
\hline Número de Sócios 250 & $\mathrm{RS}$ & $3.395,36$ & $\mathrm{R} \$$ & 738,72 & $\mathrm{RS}$ & 631,59 & $\mathrm{R} \$$ & 524,46 & $\mathrm{RS}$ & 417,33 & $\mathrm{RS}$ & 375,86 & $\mathrm{RS}$ & 108,73 \\
\hline Número de Sócios 300 & $\mathrm{RS}$ & $2.829,46$ & $\mathrm{R} \$$ & 615,60 & $\mathrm{R} \$$ & 526,33 & $\mathrm{R} \$$ & 437,05 & $\mathrm{RS}$ & 347,78 & $\mathrm{R} \$$ & 313,22 & $\mathrm{RS}$ & 90,61 \\
\hline Número de Sócios 500 & $\mathrm{RS}$ & $1.697,68$ & $\mathrm{R} \$$ & 369,36 & $\mathrm{R} \$$ & 315,80 & $\mathrm{R} \$$ & 262,23 & $\mathrm{R} \$$ & 208,67 & $\mathrm{R} \$$ & 187,93 & $\mathrm{RS}$ & 54,36 \\
\hline Número de Sócios 1000 & $\mathrm{R} \$$ & 848,84 & $\mathrm{R} \$$ & 184,68 & $\mathrm{R} \$$ & 157,90 & $\mathrm{R} \$$ & 131,12 & $\mathrm{R} \$$ & 104,33 & $\mathrm{RS}$ & 93,96 & $\mathrm{R} \$$ & 27,18 \\
\hline
\end{tabular}

Fonte: Elaborado pelo próprio autor.

O supermercado de $300 \mathrm{~m}^{2}$ tem investimento inicial de $\mathrm{R} \$ 848.839,42$, e a distribuição de cotas entre 20 e 1000 sócios pagantes. Contempla 6 (seis) períodos para análise, que variam entre $40 \%$ a $90 \%$ de todos os produtos disponíveis na loja. Nesta simulação a loja não chega a valor superavitário, ou seja, não é possível chegar ao valor de equilíbrio. Será necessário, nesta simulação, a participação do cotista independe do valor arrecadado, e neste caso não será possível utilizar os recursos arrecadados para reinvestimento ou ampliação da cooperativa. A 
participação dos cotistas variam de $\mathrm{R} \$ 9.234,05$ com 20 cotistas no primeiro período até $\mathrm{R} \$ 27,18$ no último período com 1.000 sócios.

As simulações acima descritas foram feitas desconsiderando grandes mudanças em seus custos variáveis, o que pode gerar discrepância quando aplicados de forma prática. É possível analisar que os modelos de loja de $30 \mathrm{~m}^{2}$ e $150 \mathrm{~m}^{2}$ apresentam grandes possibilidades de se tornar um projeto viável e sustentável a longo prazo, com perspectivas de crescimento, reinvestimento, e com a possibilidade de expansão. Ao contrário da loja de $300 \mathrm{~m}^{2}$ que demanda grandes investimentos iniciais, altos custos de manutenção, possibilidade de grandes perdas, com dificuldade de manter a qualidade dos produtos e serviços ao consumidor, e não apresenta indícios de sustentabilidade financeira, sem demonstrar-se superavitária.

Essas simulações foram demonstradas aos steakholders para opinião e avaliação de todos os modelos de loja. 
APÊNDICE B - FICHA PARA CONVOCAÇÃO DE ASSEMBLÉIA COOPERATIVA DE CONSUMIDORES DE PRODUTOS ORGÂNICOS DO DISTRITO FEDERAL FICHA DE CONVOCAÇÃO PARA ASSEMBLÉIA

CNPJ 00.000.000.0000/00

Telefone: (61) XXXX-XXXXX

\section{Convocação}

Convoca-se todos os interessados em criar a Cooperativa de Consumidores de Produtos Orgânicos do Distrito Federal, para a Assembleia de sua Constituição, a realizar-se em data /_____ , :___ horas, endereço .........................., com os seguintes assuntos:

1. Analise e Aprovação do Estatuto Social;

2. Eleição do Conselho de Administração (ou Diretoria) e do Conselho Fiscal;

3. Assuntos Gerais

Local

Data: 1

Assinatura da Comissão ou Presidente 
APÊNDICE C - FICHA CADASTRAL

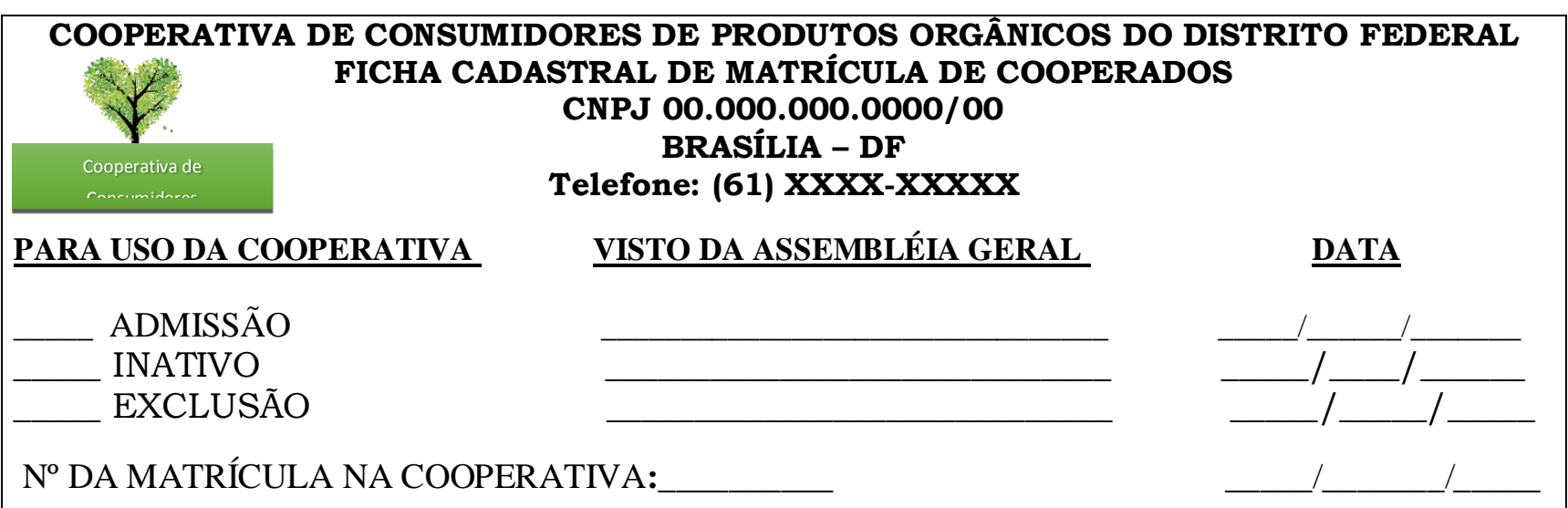

\section{DADOS PESSOAIS:}

Nome:

Data Nasc.: $\mathrm{CPF}$ :

Estado Civil:

\section{ENDERECO RESIDENCIAL:}

Rua:

Bairro:

Cidade:

CEP: UF: Fone:

Celular:

E-MAIL:

\section{ENDERECOO COMERCIAL:}

Rua:

Bairro: Cidade: CEP: UF Fone:

CAPITAL SOCIAL: Valor integralizado correspondente a R\$ (reais). TIPO DE COTA ESCOLHIDA: 
APÊNDICE D - FICHA CADASTRAL PRODUTOR

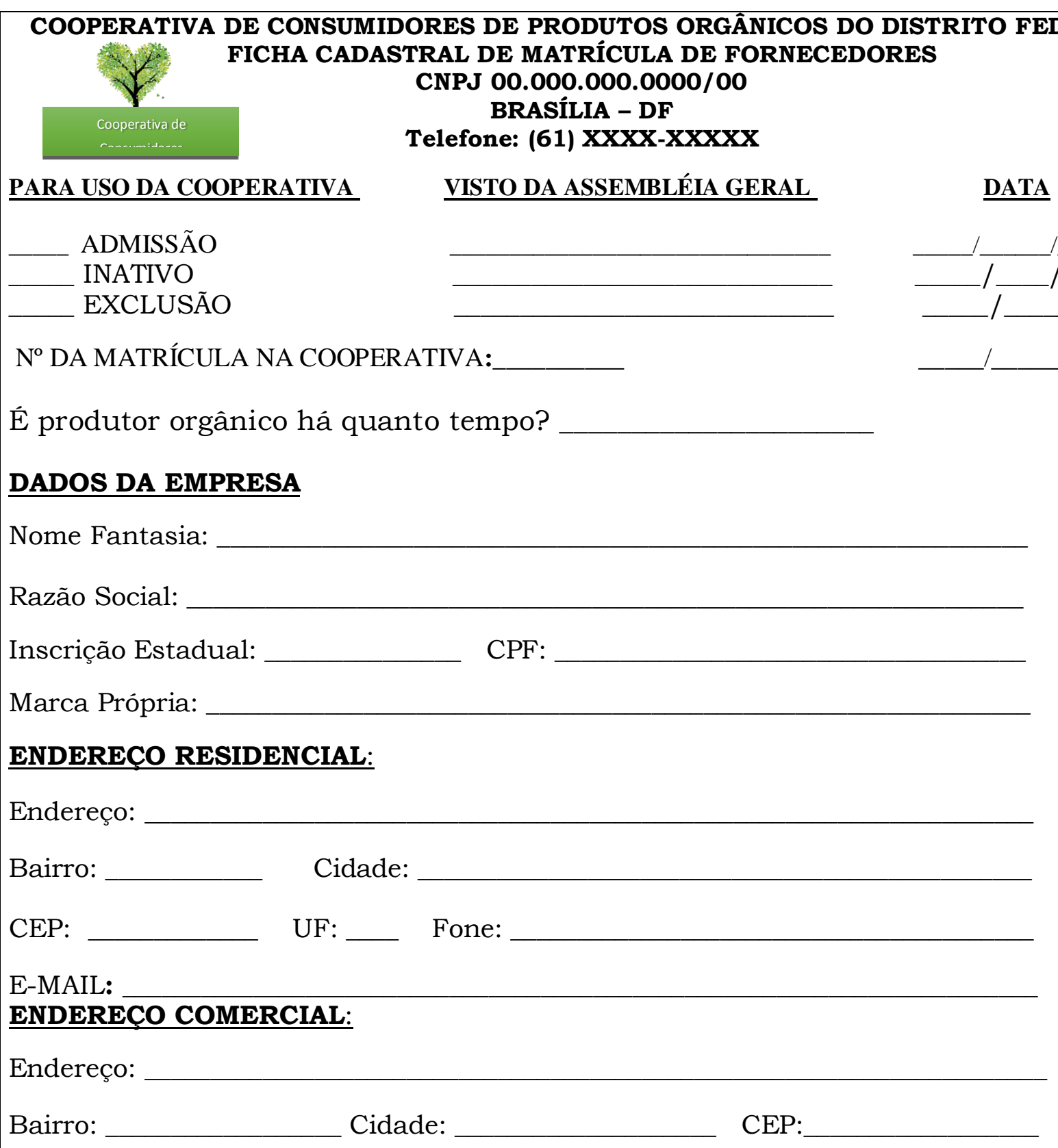

\section{PRODUTOS:}

Produtos Oferecidos (para entrega)

Todos são orgânicos e certificados?

Capacidade de máxima/mínima de produção?

\section{ENTREGA:}

Disponibilidade de entrega

Carro de entrega/ Placa

EMPREGOS E PRÁTICAS SUSTENTÁVEIS:

Número de Empregos gerados:

Práticas sustentáveis utilizadas na propriedade 


\section{APÊNDICE E - FOLHA DE PONTO COOPERADO FOLHA DE PONTO INDIVIDUAL DO COOPERADO}

\begin{tabular}{|c|c|c|c|c|c|c|c|c|c|c|}
\hline \multicolumn{9}{|c|}{$\begin{array}{l}\text { COOPERATIVA: } \\
\text { Cooperativa de consumidores de produtos orgânicos do DF }\end{array}$} & \multicolumn{2}{|c|}{ CEI/CNPJ: } \\
\hline \multicolumn{5}{|c|}{ ENDEREÇO / LOGRADOURO: } & № & \multicolumn{3}{|c|}{ BAIRRO/ DISTRITO } & & UF \\
\hline \multicolumn{5}{|c|}{ Cooperado } & & \multicolumn{3}{|c|}{ CTPS/C.I. № e SÉRIE } & \multicolumn{2}{|c|}{ DATA DEADM ISSÃO } \\
\hline \multicolumn{5}{|c|}{ FUNÇÃO } & \multicolumn{3}{|c|}{ DIA DE TRABALHO } & RIO DE TRAE & 400 & DA A SEXTA-FEIRA \\
\hline \multicolumn{5}{|c|}{ HORÁRIO SÁBADO/DOM INGO } & \multicolumn{2}{|c|}{ TURNO } & \multicolumn{2}{|c|}{ MÊS } & & ANO \\
\hline \multirow{2}{*}{\begin{tabular}{|l|l|} 
是 \\
$\mathbf{0}$ \\
\end{tabular}} & \multirow{2}{*}{$\begin{array}{l}\text { ENTRADA } \\
\text { MANHÃ }\end{array}$} & \multicolumn{2}{|c|}{ ALMOÇO } & \multirow{2}{*}{$\begin{array}{l}\text { SAÍDA } \\
\text { TARDE }\end{array}$} & \multirow{2}{*}{\begin{tabular}{c|c} 
TOTAL HS \\
NORMAIS \\
\end{tabular}} & \multicolumn{2}{|c|}{ EXTRAS } & \multirow{2}{*}{\begin{tabular}{|l|} 
TOTAL HS \\
EXTRAS
\end{tabular}} & \multirow{2}{*}{\multicolumn{2}{|c|}{$\begin{array}{l}\text { ASSINATURA OU VISTO } \\
\text { DO(A) COOPERADOO(A) }\end{array}$}} \\
\hline & & SAÍDA & RETORNO & & & ENTRADA & SAÍDA & & & \\
\hline \multicolumn{11}{|l|}{1} \\
\hline \multicolumn{11}{|l|}{2} \\
\hline \multicolumn{11}{|l|}{3} \\
\hline 4 & & & & & & & & & & \\
\hline 5 & & & & & & & & & & \\
\hline 6 & & & & & & & & & & \\
\hline 7 & & & & & & & & & & \\
\hline 8 & & & & & & & & & & \\
\hline 9 & & & & & & & & & & \\
\hline 10 & & & & & & & & & & \\
\hline 11 & & & & & & & & & & \\
\hline 12 & & & & & & & & & & \\
\hline 13 & & & & & & & & & & \\
\hline 14 & & & & & & & & & & \\
\hline 15 & & & & & & & & & & \\
\hline 16 & & & & & & & & & & \\
\hline 17 & & & & & & & & & & \\
\hline 18 & & & & & & & & & & \\
\hline 19 & & & & & & & & & & \\
\hline 20 & & & & & & & & & & \\
\hline 21 & & & & & & & & & & \\
\hline 22 & & & & & & & & & & \\
\hline 23 & & & & & & & & & & \\
\hline 24 & & & & & & & & & & \\
\hline 25 & & & & & & & & & & \\
\hline 26 & & & & & & & & & & \\
\hline 27 & & & & & & & & & & \\
\hline 28 & & & & & & & & & & \\
\hline 29 & & & & & & & & & & \\
\hline 30 & & & & & & & & & & \\
\hline 31 & & & & & & & & & & \\
\hline & & TOTA & & & & & & & & \\
\hline & & & & SUMO GE & RAL & & & & & ooperativa \\
\hline+ & \begin{tabular}{l|l}
220 & $D$ \\
\end{tabular} & ias ou Hor & as Normais & & & $\mathrm{R} \$$ & & - & & \\
\hline Tota & de Horas & & & & & $\mathbf{R} \mathbf{P}$ & & & & \\
\hline
\end{tabular}




\section{APÊNDICE F - QUESTIONÁRIO NÍVEL DE SATISFAÇÃO DE PRODUTOS ORGÂNICOS}

\section{Nível de satisfação de produtos orgânicos no Distrito Federal}

Prezado (a) Consumidor (a).

Sou pesquisador da Universidade de Brasília e realizo uma pesquisa em nossa cidade com o propósito de conhecer o nivel de satisfação dos consumidores de produtos orgánicos no Distrito Federa (DF). Este questionário faz parte de um processo de elaboração de pesquisa acadêmica. Para efetivação do estudo, gostaria de contar com sua colaboraçäo.

Por favor, leia atentamente as instruçöes deste estudo e marque a resposta que mais se aproxima com o que você pensa e/ou faz, sem deixar qualquer das questöes em branco.

Diante de sua enorme gentileza peço que responda às perguntas formuladas abaixo. Não é necessário se identificar para realização do questionário.

Desde já, agradecemos sua colaboração.

Contato da pesquisa:

Lucas Esmeraldo - Lucas esmeraldo:âmailcom

Universidade de Brasília - UnB

* Required

1. Estado civil *

Mark only one oval.

$\square$ Solteiro
$\square$ Casado
$\square$ Viúvo
$\square$ Divorciado

2. Gênero *

Mark only one oval.
Masculino
Feminino

3. Qual é o seu grau de escolaridade? * Mark only one oval.
Ensino Fundamental Incompleto
Ensino Fundamental Completo
Ensino Médio Incompleto
Ensino Médio Completo
Ensino Superior Incompleto
Ensino Superior Completo
Pós graduado
Doutorado 
4. Qual é a sua faixa etária? *

Mark only one oval.

Menos de 18 anos

18-25 anos

$28-45$ anos

46-65 anos

Mais de 65 anos

5. Qual é a sua faixa salarial?*

Mark only one oval.

Menos de R\$ 2000

RS 2001-4000

RS 4001-6000

RS $6001-8000$

RS $8001-10.000$

Acima de RS 10.000

Prefiro näo responder

6. Você consome produto orgânico? *

Mark only one oval.

Sim Skip to question 8

Não

Não consome produto orgânico

Principal Motivo

7. Qual principal motivo de você NÃO consumir produto orgânico? * Mark only one oval.
Não conheço
Skip to question 15.
Não percebo qualidade Skip to question 15
Não vejo diferença entre produto convencional e orgânico
Skip to question 15.
Preço alto
Skip to question 15
Dificuldade em encontrar produtos de minha preferência
Skip to question 15.
Other.
Skip to question 15.

Skip to question 15.

\section{Motivos de consumo}

Produtos orgânicos que você consome 
8. Quais produtos você geralmente consome? * Check all that apply.
$\square$ Hortaliças
Frutas
Legumes
$\square$ Came vermelha
Came branca
$\square$ Leite
$\square$ Café
Other:

9. Onde você costuma comprar produtos orgânicos? * Check all that apply.

$\square$ Feira - CEASA

$\square$ Feira de produtos orgânicos - Proximidade de Casa

$\square$ Feira de produtos orgânicos - Proximidade do trabalho

$\square$ Hipermercado

$\square$ Supermercado

$\square$ Internet (Sites de produtos orgânicos)

$\square$ Restaurante de produtos orgânicos

$\square$ Empónios/Lojas especializadas

10. Em algum desses ambientes (questäo anterior) você já fez algum tipo de reclamação? * Mark only one oval.

Sim

Não Skip to question 13.

\section{Reclamação}

11. Qual foi o tipo de reclamação?

Check all that apply.

Relacionada à qualidade do produto

$\square$ Relacionada aos funcionários (cortesia/empatia)

$\square$ Relacionada ao preço

$\square$ Relacionada à origem do produto (confiança)

$\square$ Relacionada ao ambiente de venda dos produtos (estética)

Other: 
12. Como se procedeu a reclamação que você fez? *

Check all that apply.

$\square$ Reclamou com funcionário da loja/gerente da loja no momento da insatisfaçäo

$\square$ Reclamou por escrito em sites ou orgãos de defesa do consumidor

$\square$ Deixou de comprar naquela loja

$\square$ Influenciou seus amigos e familiares a não comprarem mais naquela loja

Promoveu ação judicial contra a loja

\section{Em relação a motivação de compra}

13. Por qual motivo, geralmente, você prioriza ao comprar produto orgânico? Marque atribuindo nota de 1 a 5 , sendo 1 sem importância e 5 extremamente importante. * Mark only one oval per row.

\begin{tabular}{|c|c|c|c|c|c|}
\hline & $\begin{array}{l}1 \text { - Sem } \\
\text { importância }\end{array}$ & $\begin{array}{l}2 \text { - Pouco } \\
\text { importante }\end{array}$ & $\begin{array}{c}3 \text { - } \\
\text { Importante }\end{array}$ & $\begin{array}{l}4 \text { - Muito } \\
\text { importante }\end{array}$ & $\begin{array}{c}5 \text { - } \\
\text { Extremamente } \\
\text { importante }\end{array}$ \\
\hline \multicolumn{6}{|l|}{$\begin{array}{l}\text { Aparência/Aspecto } \\
\text { Visual }\end{array}$} \\
\hline \multicolumn{6}{|l|}{ Marca } \\
\hline \multicolumn{6}{|l|}{ Saúde } \\
\hline \multicolumn{6}{|l|}{ Sabor } \\
\hline \multicolumn{6}{|l|}{ Riqueza nutricional } \\
\hline \multicolumn{6}{|l|}{$\begin{array}{l}\text { Selo de } \\
\text { responsabilidade } \\
\text { social }\end{array}$} \\
\hline \multicolumn{6}{|l|}{$\begin{array}{l}\text { Selo de } \\
\text { responsabilidade } \\
\text { ambiental }\end{array}$} \\
\hline \multicolumn{6}{|l|}{ Preço } \\
\hline \multicolumn{6}{|l|}{$\begin{array}{l}\text { Influência de } \\
\text { Família/Amigos }\end{array}$} \\
\hline \multicolumn{6}{|l|}{ Influência da mídia } \\
\hline \multicolumn{6}{|l|}{$\begin{array}{l}\text { Origem do produto } \\
\text { (confiança) }\end{array}$} \\
\hline $\begin{array}{l}\text { Disponibilidade do } \\
\text { produto }\end{array}$ & & & & & \\
\hline
\end{tabular}


14. Qual seu nível de satisfação em relação ao ambiente que você compra produtos orgânicos? Marque atribuindo nota de 1 a 5 , sendo 1 Insatisfeito e 5 muito satisfeito. * Mark only one oval per row.

\begin{tabular}{|c|c|c|c|c|c|}
\hline & $\begin{array}{c}1- \\
\text { Insatisfeito }\end{array}$ & $\begin{array}{l}2 \text { - Pouco } \\
\text { Satisfeito }\end{array}$ & $\begin{array}{c}3- \\
\text { Satisfeito }\end{array}$ & $\begin{array}{l}4 \text { - Muito } \\
\text { satisfeito }\end{array}$ & $\begin{array}{c}5 \text { - } \\
\text { Extremamente } \\
\text { satisfeito }\end{array}$ \\
\hline \multicolumn{6}{|l|}{ Localização } \\
\hline \multicolumn{6}{|l|}{ Conforto } \\
\hline \multicolumn{6}{|l|}{$\begin{array}{l}\text { Sensaçäo de } \\
\text { segurança no } \\
\text { momento da compra }\end{array}$} \\
\hline \multicolumn{6}{|l|}{$\begin{array}{l}\text { Limpeza do ambiente } \\
\text { de compra (gôndolas, } \\
\text { freezers) }\end{array}$} \\
\hline \multicolumn{6}{|l|}{$\begin{array}{l}\text { Conhecer o produtor } \\
\text { rural (conhecido, } \\
\text { colega, amigo) }\end{array}$} \\
\hline \multicolumn{6}{|l|}{$\begin{array}{l}\text { Aparência/Cortesia } \\
\text { dos funcionários }\end{array}$} \\
\hline \multicolumn{6}{|l|}{$\begin{array}{l}\text { Formas/Meio de } \\
\text { pagamento }\end{array}$} \\
\hline \multicolumn{6}{|l|}{$\begin{array}{l}\text { Descontos e } \\
\text { promoções }\end{array}$} \\
\hline $\begin{array}{l}\text { Variedade de produtos } \\
\text { orgânicos }\end{array}$ & & & & & \\
\hline
\end{tabular}

\section{Cooperativa de Consumo}

Entende-se por cooperativa de produtos orgánicos: "várias pessoas se juntam para fazer compras unificadas, com isso fazem compras em maior quantidade e assim conseguem comprar diretamente dos produtores, isto é, compras sem intermediários".

15. Você teria interesse em participar de uma cooperativa de compras de produtos orgânicos? *

Mark only one oval.

Sim

Não Skip to question 17.

\section{Seção sem título}

16. Quais das vantagens de uma cooperativa de compras de produtos orgânicos você tem maior interesse? *

Check all that apply.
Desconto - Preço
Garantia de origem do produto
Preocupação Social
Preocupação Ambiental
Variedade de produtos
Acesso a produtos exclusivos
- Comodidade
Other: 
17. Quais fatores possivelmente motivariam você a aderir a um modelo de cooperativa de consumo de produtos orgânicos? *

Check all that apply.

$\square$ Desconto - Preço

Garantia de origem do produto

Preocupação Social

Preocupação Ambiental

Variedade de produtos

- Acesso a produtos exclusivos

$\square$ Comodidade

Other: 


\section{APÊNDICE G - QUESTIONÁRIO ANÁLISE COMPETITIVA DOS CANAIS DE Análise competitiva dos canais de comercialização de produtos orgânicos no Distrito Federal}

Prezado (a) Consumidor (a)

Solicito a sua colaboração para participar de uma pesquisa acadêmica realizada pelo aluno Lucas Augusto Esmeraldo de Oliveira, da Universidade de Brasília - UnB, que tem como objetivo ANÁLISE COMPETITIVA DOS CANAIS DE COMERCIALIZAÇÃO DE PRODUTOS ORGÂNICOS NO DISTRITO FEDERAL (DF). Os dados coletados servirão como base para realização deste estudo. Toda informação fornecida será mantida em sigilo de fonte, NÃO SENDO NECESSÁRIO IDENTIFICAR-SE.

Obrigada por sua colaboração.

Contato da pesquisa:

Lucas Esmeraldo - lucas esmeralde@amailcom

${ }^{*}$ Required

1. Gênero *

Mark only one oval.
Masculino

Feminino

2. Estado civil *

Mark only one oval.

Casado

Solteiro

3. Você possui filhos? *

Mark only one oval.

Sim

Não

4. Qual seu grau de escolaridade? *

Mark only one oval.
Ensino Fundamental
Ensino Médio
Ensino Superior
Pós Graduação

5. Qual é a sua faixa etária? *

Mark only one oval.

Menos de 18 anos

$18-25$ anos

$26-45$ anos

$46-65$ anos

Mais de 65 anos 
6. Qual é a sua faixa salarial? *

Mark only one oval.

Menos de $\mathrm{R} \$ 2.000$

$\mathrm{R} \$ 2.001-4.000$

$R \$ 4001-6.000$

$R \$ 6.001-10.000$

Acima de $\mathrm{R} \$ 10.000$

Prefiro não responder

7. Você consome produtos orgânicos *

Mark only one oval.

$C_{\text {Não }}$ Skip to question 9.
Skip to question 8.

\section{Não consome produtos orgânicos}

Principal motivo

8. Qual principal motivo de você NÃO consumir produto orgânico? Mark only one oval.

Não conheço

Não percebo qualidade

Não vejo diferença entre produtos convencional e orgânico

Preço alto

Stop filling out this form.

\section{Motivos de consumo}

principal motivo

9. Qual o principal motivo de você consumir produtos orgânicos? Mark only one oval.

Preocupação com a saúde

Preservação do meio ambiente

Por ser um produto certificado

Por ser mais saboroso

Por ajudar o pequeno agricultor

Influência família/amigos

10. Com qual frequência você compra produtos orgânicos? Mark only one oval.

Diariamente

Semanalmente

Quinzenalmente

Mensalmente 
11. Qual seu gasto mensal com produtos orgânicos?

Mark only one oval.

Menos de $\mathrm{R} \$ 100$

$R \$ 101-200$

$R \$ 201-300$

$\mathrm{R} \$ 301-400$

$\mathrm{R} \$ 401-500$

Mais de 500

12. Qual produto orgânico você mais consome?

Mark only one oval.

Hortaliça

Frutas

Legumes

Carne vermelha

Carne branca

Leite

Café

13. Qual o principal local você costuma comprar produtos orgânicos? Mark only one oval,
Hipermercado/Supermercados
Skip to question 14.
Feiras
Skip to question 15.
Internet (sites de produtos orgânicos)
Skip to question 16.
CSA - Comunidade que sustenta a agricultura Skip to question 17.
Empório/Lojas especializadas
Skip to question 18.

Fatores importantes na compra em hipermercados/supermercado 
14. Quais fatores são importantes ao realizar a compra de produtos orgânicos em Hipermercados/Supermercados?

Mark only one oval per row.

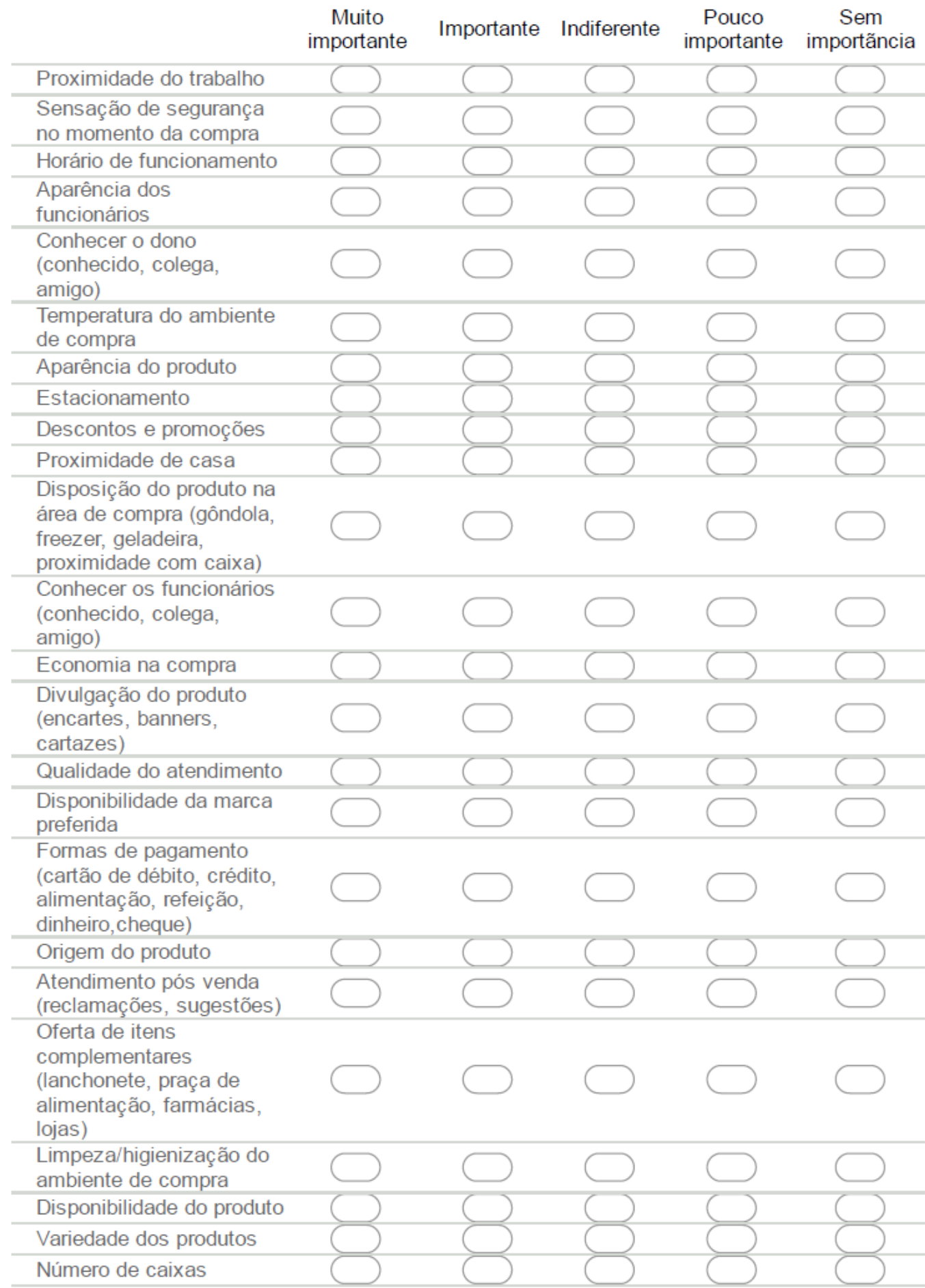

Stop filling out this form.

\section{Fatores importantes na compra em feiras}


15. Quais fatores são importantes ao realizar a compra de produtos orgânicos em Feiras ? Mark only one oval per row.

Muito Importante Indiferente Pouco Sem importante Importante Indiferente importante importância

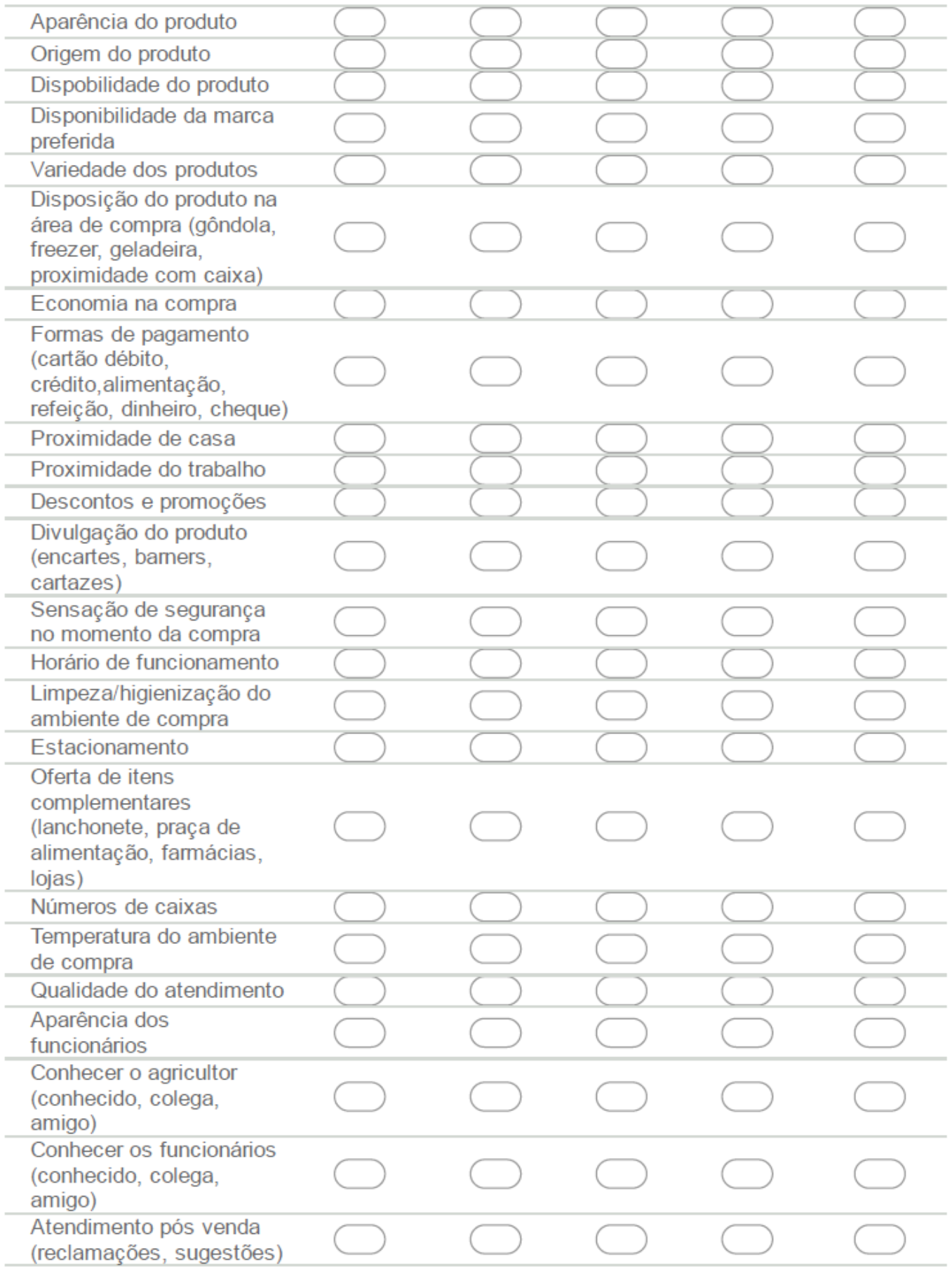

Stop filling out this form

\section{Fatores importantes na compra pela internet}


16. Quais fatores são importantes ao realizar compra de produtos orgânicos na internet? Mark only one oval per row.

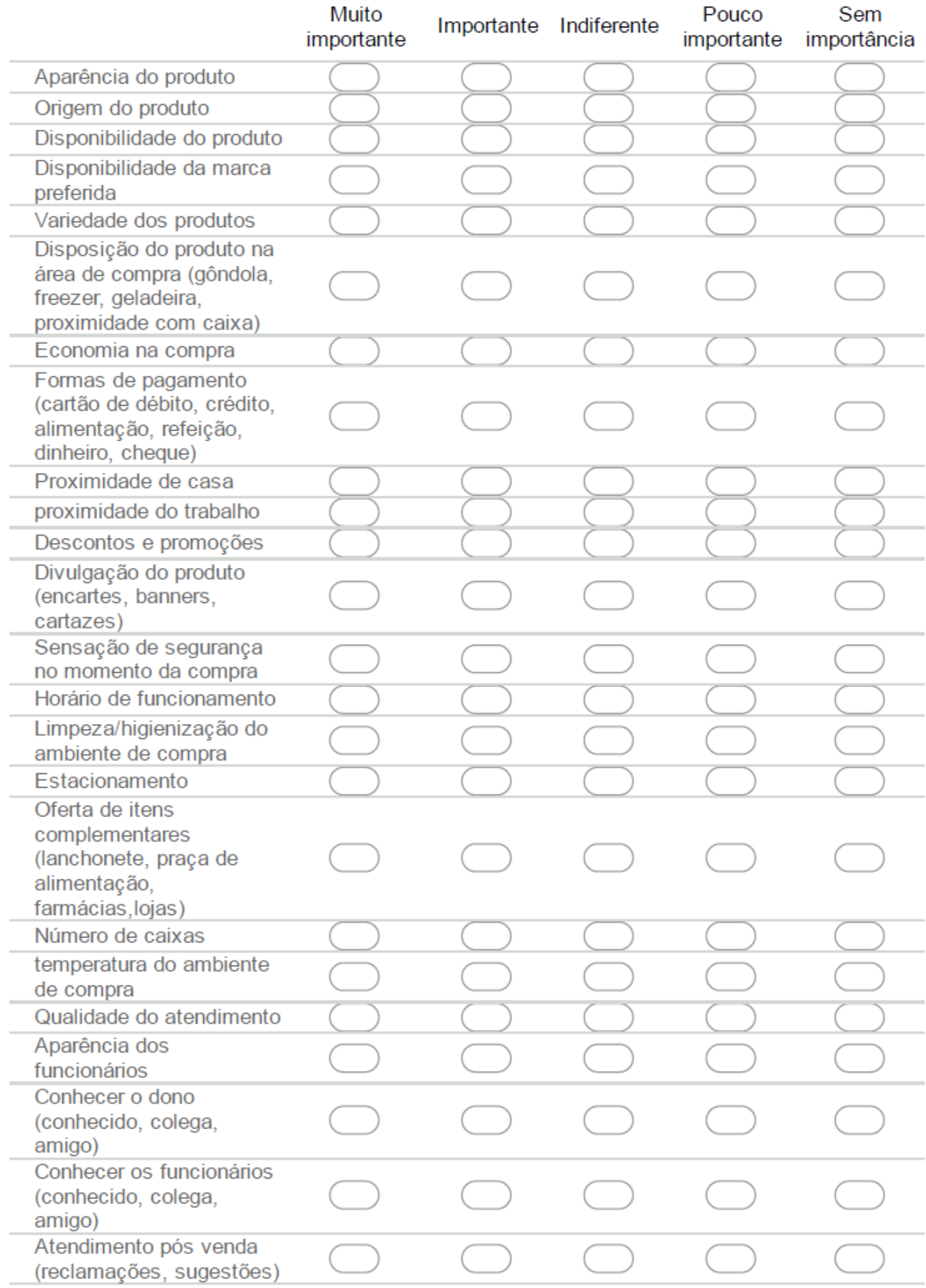

Stop filling out this form.

\section{Fatores importantes na compra em CSA - Comunidade que sustenta a agricultura}


17. Quais fatores são importantes ao realizar a compra de produtos orgânicos em CSA? Mark only one oval per row.

Aparência do produto
Origem do produto
Disponibilidade do produto
Disponibilidade da marca
Variedada dos produtos
Disposição do produto na
área de compra (gôndola,
preezer, geladeira,
Econidade com caixa)
Formas de pagamento compra
(cartão débito, crédito,
alimentação, refeição,
dinheiro, cheque)
Proximidade de casa
Proximidade de trabalho
Descontos e promoções
Divulgtação do produto
(encartes, banners,
cartazes)
Sensação de segurança
no momento da compra
Horário de funcionamento
Limpeza/higienização do
ambiente de compra
Estacionamento
Oferta de itens
complementares
(lanchonete, praça de
alimentação, farmácias,
lojas)
Número de caixas
Temperatura do ambiente
Qe compra
Apalidade do atendimento
funcionciários dos
Conhecerer o dono
(conhecido, colega,
amigo)
Conhecer os funcionários
(conhecido, colega,
amigo)

Stop filling out this form.

Fatores importantes de compra empório/lojas especializadas 
18. Quais fatores são importantes ao realizar a compra de produtos orgânicos em empórios/lojas especializadas?

Mark only one oval per row.

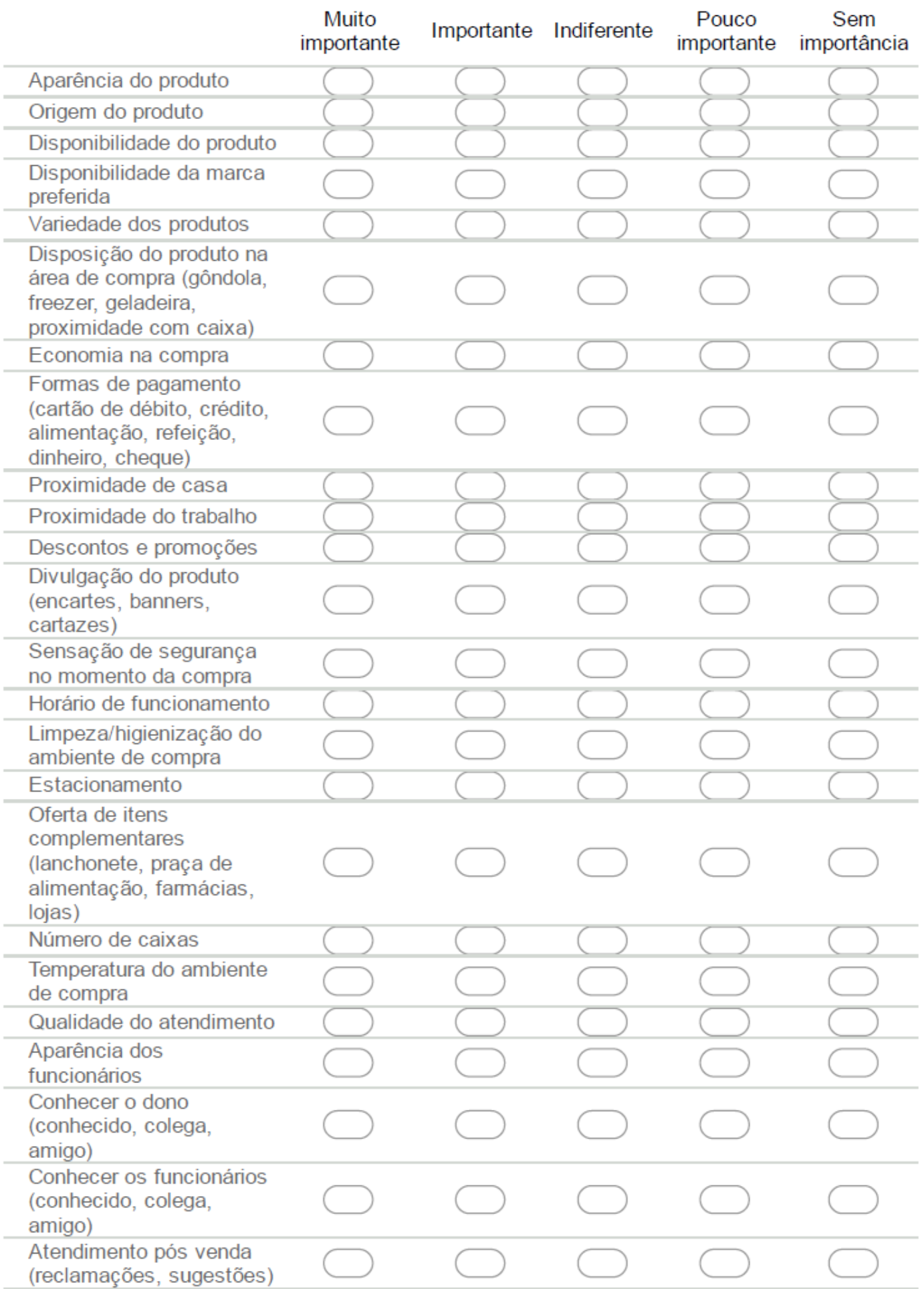




\section{APÊNDICE H - ENTREVISTA ECOTORRES}

Entrevista Visita técnica realizada na cooperativa de Consumidores de produtos orgânicos em Torres - Rio Grande do Sul - EcoTorres.

Entrevistador: É muito bom hein.., Pra não ter problema, pode esquecer, não tem problema...

Entrevistada: Como eu estava falando, foi criada em 2000, por pessoas... Porque realmente há 16 anos atrás não encontrava. “Ah, eu quero um produto orgânico”, não tinha...

Entrevistador: Não tem.

Entrevistada: Teria que ir a Porto Alegre, o lugar mais próximo para poder comprar o produto. Então, o grupo de doze pessoas que resolveram montar uma cooperativa para ter onde expor esses produtos.

Entrevistador: Porque eles não são produtores?

Entrevistada: Não. São consumidores. É uma cooperativa de produtores e consumidores. Mas quem fundou foi consumidores, na verdade. Então, eles fizeram essa reunião e começaram... Vamos expandir para outras pessoas. Foi onde 120 sócios se cadastraram na época, durante uns dois ou três anos ali...Cento e vinte, hoje tem uns inativos, mas tem os ativos também. Daí foram aglomerados os produtores juntos, e começaram a trazer, cada um trazer um pouco de mercadoria, aí escolheram o pessoal para trabalhar...

Entrevistador: Quem trabalha não são os sócios?

Entrevistada: Não são sócios, são funcionários, são remunerados, conforme a lei e tal... Entrevistador: Celetistas, CLT, tudo...

Entrevistada: Isso. Tudo certinho. Foi gerando o produto... A gente tinha no início aquele negócio: A gente paga uma anuidade, na época 60 reais, e nunca mais foi pago nada. Foi só uma taxa na verdade, e daí tinha um desconto e tal... porque na época o pessoal não tinha aquela visão toda... "Ah o produto orgânico, é uma coisa legal". Perguntam, qual é a diferença? Ainda hoje há isso. Porque qual a diferença entre o orgânico e o convencional? Naquela época mesmo e ainda né. Por isso que não havia tanta lógica. E daí foram passando os anos, e foi quando 
nossa cooperativa quase faliu. Porque a gente dava um desconto só que ninguém retornava com valor monetário para preencher essa lacuna...

Entrevistador: Para manutenção, custos...

Entrevistada: Porque a gente tem um preço mais acessível, mas a gente tem todas as contas que uma empresa tem, e até mais, porque aqui nada é sonegado né. Como são vários sócios tem que ser tudo no papel... Foi quando a gente cortou esse negócio de...

Entrevistador: Cota e desconto para quem é cotista.

Entrevistada: Isso. E pra renovar os sócios, oito, sete anos foi extinto. O pessoal que é sócio, que tem a fichinha, continua, que é sócio, porém não tá tendo força, aquela coisa toda. E daí a gente conseguiu com os sócios que já estavam aqui na coordenação, eles deram um valor para poder reerguer a cooperativa, e botar para gerar mais capital, ter mais produto, e foi quando a gente conseguiu se fortalecer e foi trocando de loja, deste ponto até o início a gente já teve quatro ou cinco estabelecimentos. Este é o maior. Aí agora a gente tá pensando em reabrir para nossos sócios, fazendo um recadastramento para ver quem quer também se associar. A gente tá estudando uma maneira para que possa ter futuros benefícios mas vai ter taxas né, porque não tem como manter um lugar, só vai dar o benefício, e não vai ter o retorno. Então a gente tá estudando ainda como vai acontecer esse negócio.

Entrevistador: Uma troca de lugar, a evolução até chegar aqui. Essa evolução foi sempre por demanda, por estar aumentando demanda, por ter espaço maior...

Entrevistada: Isso mesmo. Quatro anos, quase cinco lá no antigo negócio. A gente ficava.... Vamos crescer, a gente foi crescendo naquele lugar, mas tem um momento que não tem mais para onde crescer, e não tem espaço né...

Entrevistador: Espaço físico né!

Entrevistada: Não dá para crescer para cima e pros lados, enfim, foi onde a gente estava estudando vários lugares, até então que a gente chegou aqui. E faz tempo que a gente queria o café. Se for procurar não tem. Um lugar pra comer o orgânico, não tem. Tem várias cafeterias sim. E uma delas é que tem café orgânico para servir na cafeteria.

Entrevistador: Tudo convencional... 
Entrevistada: Tudo convencional. E nós temos. Todos os produtos, pasteizinhos, torta, doce, tudo é feito com tudo orgânico. Ovo, farinha, leite, tudo, tudo, tudo. Tem coisa que não é integral, é branca, mas é orgânica. O princípio é: orgânico!

Entrevistador: Entendi.

Entrevistada: Aqui na loja até entra coisa que não são orgânicas, mas nada transgênico, sem conservante...

Entrevistador: De onde surgiu essa ideia? Você sabe de onde surgiu essa ideia mesmo? Essa necessidade? Essa motivação?

Entrevistada: Não sei se tu conheces o centro Ecológico, Dom Pedro de Alcântara. É uma rede, em Caxias, que foi trazido uma filial para Dom Pedro de Alcântara...

Entrevistador: Que são certificadores?

Entrevistada: Que são certificadores. Eles dão auxílio para os produtores. Daí eles começaram a trazer essa ideia e o pessoal começou a ver que existia essa possibilidade. E os nossos sócios daqui; o pessoal que fundou a cooperativa, tem de Brasília, tem de Minas Gerais, que vieram trabalhar aqui, que são os fundadores, foram eles que trouxeram a ideia. E aí falaram: a gente, quem sabe, produto orgânico é melhor pra saúde... e aquela coisa toda foi cativando o resto do pessoal. Foi onde começou a juntar tanta gente. Porque até todo mundo pensou, que tem tantos sócios, é muita gente né...

Entrevistador: Mas por cooperativa é razoável né.

Entrevistada: Por cidade pequena, mas, hoje em dia não seria, mas na época sim. Na época era bastante gente.

Entrevistador: E em relação a preço, qual é a principal dificuldade de vocês? Em relação ao convencional, quando se fala de mercado?

Entrevistada: Ontem mesmo a gente estava tendo essa preocupação, porque a gente estava vendo um negócio no nosso sistema pra ficar tudo certinho, aquela coisa no sistema de controle de estoque... A gente tem muito problema com firma, com transportadora, porque trata o produto errado, e a gente manda de volta, e ele diz que não tem que aceitar, e a gente acaba muitas vezes obrigando a aceitar porque não tem de onde comprar, porque produto orgânico não é assim, você vai em qualquer esquina e encontra. Não tem! É muito difícil. Tanto que a 
gente custa a trazer, de longe às vezes. O problema que a gente tem também e das hortaliças, frutas... Perguntam: Porque você não tem mamão, não tem uva, abacaxi? Porque? Porque não é época na cidade, na região, e não tem como trazer tudo. Às vezes as pessoas não entendem. Alguns claro, que são flexíveis, sabe que o que é de época, é o que é orgânico.

Entrevistador: Já tem essa cultura né?

Entrevistada: É. Tem pessoas que acham que não tem diferença. Que o orgânico é só uma fachada, mas não é. E quando o pessoal conhece que tem uma certificação e vê quanto é rigoroso e é difícil uma certificação de orgânico.

Entrevistador: Tudo aqui é certificado?

Entrevistada: Tudo. De hortaliças, todas essas coisas... Nada entra aqui entra sem a certificação. As vezes chega um que fala: eu planto no quintal lá de casa e não coloco nada. Se tiver certificado, traz e a gente conversa. Mas, a maioria não tem certificado, e a gente, infelizmente não pode. Esse dias veio uma fornecedora que nos fornece ovo e vai começar a fornecer outros pra gente. Ela tá começando a plantar moranguinho. Só que o moranguinho dela ainda não tem certificado, vai ter o processo. Daí a gente entrou com essa ideia pro conselho, pros sócios, que a gente já poderia estar começando a vender. Só que eles não liberaram justamente pelo fato dela não ter a selagem do orgânico dela.

Entrevistador: Como lei né. A garantia é pelo selo.

Entrevistada: Sim, porque é um caso de fiscalização. Eu estou te garantindo que não tem veneno. Como é que eu vou te vender uma coisa que não tem veneno? Isso é ilegal, é propaganda enganosa.

Entrevistador: Em algum momento você pode ter problema.

Entrevistada: Então a gente prefere às vezes não ter o produto do que arriscar com isso.

Entrevistador: Em relação a concorrente, você tem algum?

Entrevistada: Temos na cidade sete lojas de produtos naturais, porém tem duas, uma, no caso nós, e mais uma que vende as hortaliças, mas ela não chega perto da gente na quantidade. Porque o comércio dela é bem menor que o nosso. Porque eles não focam tanto nisso. É orgânico. Eles têm tipo, dois alfaces e uma banana por exemplo. Não é aquela coisa que 
prevalece o orgânico. E as outras se preocupam mais com integral e não no orgânico. E também são lojas. A cooperativa não tem nenhuma.

Entrevistador: Isso que eu ia te perguntar: vocês hoje são Cooperativa e se veem como cooperativa ou se veem já como loja?

Entrevistada: Não. Como cooperativa... A gente é cooperativa. Tudo tem uma burocracia maior que uma loja. Tudo que vai entrar tem que passar pelos sócios, conselho, pra depois aprovar, então tudo lá é mais né, do que uma loja convencional que só tem um dono. Às vezes é difícil porque um quer uma coisa, o outro quer de outra, o outro quer de outra... Daí, tem que entrar num consenso pra ver qual que é melhor.

Entrevistador: Pra formação de preço, como é que vocês fazem?

Entrevistada: No começo... É bem difícil, todo produtinho que entrar você passar por um associado... Então, tem a gerente que trabalha há 13 anos aqui já, ela é parte da mobília da loja já... Ela que ajudou a reerguer, a fundar não, porque na época ela nem sabia daqui. Ela trabalhou na casa de uma das fundadoras, e foi onde ela conheceu e trouxeram ela pra cá, e ela que tem o livre arbítrio de decidir o quanto de preço. Mas assim, tu compras um pé de alface por R $\$ 1,00$ e não vendo mais que $R \$ 1,50$, e dentro desses 0,50 que eu ganhei eu tenho que pagar o fundo rural, o imposto disso, então não tem como tu ganhar muito entendeu. Quase 30, 40\%. Assim, os sucos, o vinho... O vinho é uma coisa que tu bota no comércio normal $80 \%$ tranquilamente. A gente não bota mais de $20 \%$, porque já é um produto bem caro. Daí a gente já não bota muito pra poder não assustar o cliente e pelo fato da gente ser cooperativa, porque a gente não visa lucro. Todo dinheiro que entra na loja fica na loja. Nem os próprios associados não ganham. Claro, que seu um dia houver a possibilidade de dar muito dinheiro, o que é difícil, vai ser distribuído. Mas não, é só investido na própria loja.

Entrevistador: E divulgação? Pra convencer o povo pra entrar?

Entrevistada: É mais na internet. Porque na rua não é tão legal, uma cooperativa, devido a poluição ambiental, tu não vais colocar panfleto na rua. Colocar um carro de som, vai dar poluição sonora. E daí tudo a gente tem uma preocupação pra fazer. Tudo tem que ser pensado antes de fazer. A gente usa muito Facebook. A gente tem que fazer de uma forma muito boa assim, de aceitação de pessoal, de comunicação. E a gente tem o Centro Ecológico, que é a nossa assessoria, digamos assim. E eles ajudam na forma de divulgação, eles fazem bastante 
palestra, fora e até no exterior, que é quando eles levam os nomes das cooperativas, inclusive a nossa pro resto do pessoal.

Entrevistador: E vocês tem apoio a eles? Tem algum tipo de recurso destinado?

Entrevistada: Sim. Às vezes eles fazem projeto, e dependendo do projeto, é revestido pra nós. No início da nossa longa jornada, eles ajudaram a gente por um bom tempo, através de um projeto pra ajudar a pagar o aluguel. A gente não tinha condições de pagar o aluguel. E agora quando a gente mudou pra essa loja de novo, eles fizeram um projeto pra comprar equipamento pra cá, tipo freezer, essas coisas, porque a gente não tinha dinheiro pra comprar.

Entrevistador: E vocês receberam em forma de doação?

Entrevistada: Isso. É um projeto que eles fizeram e passaram pra gente.

Entrevistador: Tanto do Café quanto da Loja?

Entrevistada: Sim. O Café e a Loja são o mesmo negócio. É tudo igual. Tudo é do mesmo lugar, tanto que o que passa lá é passado aqui com a gente.

Entrevistador: Eu vi que as meninas tem livre acesso... E ambientação física? Reforma? Isso é com vocês? Teve projeto?

Entrevistada: Sim, esse prédio, todo muno pensa que é público, mas não, é privado, e estava abandonado o prédio, e a gente tinha vários projetos... E a gente queria tanto, que a gente conseguiu a liberação pra locação, porque eles não iriam locar o prédio. Não estava aberto pra locação nenhuma. Só que gente mostrou o projeto, eles viram o que era, e decidiram abrir pra gente e por isso que a gente consegue pagar o aluguel porque é só um valor simbólico, porque se não a gente também não teria condição de pagar um aluguel numa esquina.. faixa de uns 15 mil o aluguel aqui. E a gente conseguiu só pelo valor da bonificação, pra dizer que a gente tá aqui e pra manter o prédio, porque estava abandonado, a gente deu uma nova vida pro prédio. E daí a gente teve que fazer projeto pra entrar com uma obra, aquela coisa toda... Teve a designer pra fazer decoração. Tudo teve alguém envolvido por trás...

Entrevistador: E pedido? Número de fornecedores, pedidos? Tem itens que são devolvidos, não tem?

Entrevistada: Na parte desses perecíveis, como as hortaliças, frutas, sim. A maioria sim. Ao menos quando vem de fora, como a gente estava trazendo cebola de São Paulo porque não tem 
aqui. E não tem como devolver. Tu compras um número $\mathrm{X}$, e tem prejuízos como a gente teve, paciência... Mas coisas aqui, como verdinhos, vem aqui da região. Aí a gente tem um acordo com eles, se não vender a gente desconta. Claro, tem alguns fornecedores que ainda são um pouco menos flexíveis: Faz o pedido, e se eu trouxer a mais pode descontar, fica o número do teu pedido, fica por aquilo mesmo. Tudo bem, a gente acha né... Mas as vezes a gente desconta, quando eles dão a liberdade. A gente sempre procura assim: A beterraba ele trouxe um monte, daí tu baixas pra gente, a gente baixa pro consumidor também. Que daí ninguém tem prejuízo.

Entrevistador: Alguém que oferta beterraba... Tem mais de um produtor?

Entrevistada: Não, pelo menos nessa parte de hortaliças, a gente tem um que é só pra banana, aí um que tem banana, alface, etc...E tem mais um que traz durante a semana um revezamento de todas essas hortaliças também. A quantidade de hortaliças que um traz o outro traz também.

Entrevistador: Como é que escolhe?

Entrevistada: A gente tem o dia. Por exemplo a gente tem o Elias, que é o produtor mais firme e forte assim, ele abastece a loja segunda, quarta e sábado. Esses dias são dele. Daí ele traz a banana e traz o verde. Isso é dele, acabou a história, naquele dia todo mundo sabe que é ele que traz.

Entrevistador: Tudo é determinado pelo conselho?

Entrevistada: Pelo pessoal da loja. Enfim, na terça-feira tem um outro fornecedor que traz, hoje teve um outro. Daí vai intercalando. Cada um sabe o seu. Claro, acontece, um fala: Ah, surgiu um produto que um não tem, eu tenho, tu quer? Quero, claro! Então aceito, independente...

Entrevistador: Consignado eles não deixam?

Entrevistada: Deixam. Quando é um produto assim mais caro, que digo que não sei se vai vender não. Ele deixa aqui. Tudo de boca a boca, assim, mas tudo com nota de produtor, eles trazem, tudo certinho...

Entrevistador: Que bacana! Cadastro é só com busca mesmo? Achou um produtor.. Cadastra... Entrevistada: Sim, tem bastante informações, é corporativo, é uma rede também...

Entrevistador: É a do suco...

Entrevistada: É a coletiva do suco, é empresa. 
Entrevistador: Aquilo é uma cooperativa?

Entrevistada: É uma cooperativa também, de produtor, que daí ela pega os produtos e revende para as outras cooperativas. Inclusive há agora de merenda escolar...

Entrevistador: Vocês industrializam algum produto?

Entrevistada: Não! O que a gente faz é fracionar o produto.

Entrevistador: O a granel alí...

Entrevistada: Sim, como o açúcar. A gente compra todos eles da Native. Só que a gente tem dois tipos se tu for observar alí... Esse e esse são o mesmo açúcar, mas esse tá bonitinho, por que tem gente que quer...Ele é o mesmo produto, da mesma empresa, porém ele vem em saca de $50 \mathrm{~kg}$, e a gente acaba fracionando pra tornar mais barato pro consumidor. Por exemplo, tem $\mathrm{R} \$ 7,50$ e um de $\mathrm{R}$ \$ 6,90, é o mesmo produto, só a embalagem que é diferente. E a gente faz isso com várias outras coisas.

Entrevistador: E o consumidor em algum momento reclama?

Entrevistada: Não. Tem gente que gosta mais desse produto, porque é mais resistente, ou vai dar de presente... Mas não, vende muito mais, vende $70 \%$ mais os produtos fracionados que os produtos embalados. Quando tem opção de fracionado e embalado.

Entrevistador: Assim, ele sabendo que é fracionado, mesmo sabendo que é de um fornecedor que é certificado, ninguém reclama em virtude do selo. Da embalagem?

Entrevistada: Quem não conhece, que é um cliente novo, que não conhece a história de orgânico, e diz: não tem o selo, não vou confiar. Mas a gente tem o certificado, o papel da certificação em mãos. Posso mostrar, claro. Mas sempre tem aquela pessoa que vai dizer que acha que não. Eu prefiro o selo, se não tem o selo...

Entrevistador: E pretensão de marca própria para colocar na embalagem?

Entrevistada: Não, a gente não tem.

Entrevistador: Tipo Native, Eco Torres, identidade visual...

Entrevistada: Não. Até porque, pra gente colocar a nossa marca a gente tem que ter uma patente, direitos autorais, etc... A gente não tem porque a gente e não produz nada. 
Entrevistador: A estrutura como, visão, missão, valores, características de empresa, vocês tem?

Entrevistada: CNPJ, essas coisas?

Entrevistador: Isso como a parte legal tudo bem, mas o que eles consideram como a alma de empresa, por exemplo, a missão da gente é oferecer produtos...

Entrevistada: Ah sim, a gente até tem um lema, que está posto no mural da gente aqui, que o seu jeito de consumir é o seu jeito de preservar, porque a gente sempre luta pela preservação do meio ambiente, o consumo sustentável, tem sempre essa história por trás de tudo. Tanto que as sacolas a maioria dos clientes trazem, quando eles vão fazer a feira eles trazem a sua sacola. A gente já fez vários projetos quanto a isso, sobre produto orgânico, leva esse porque é orgânico... Tem uma política, vamos dizer assim...

Entrevistador: Ah maravilha. É isso, que eu me lembre só.

Entrevistada: Dificuldade sempre tem, porque é uma coisa mais difícil de se lhe dar, tanto que por exemplo uma farinha convencional e uma farinha orgânica, o orgânico dura muito menos na prateleira. A gente acaba perdendo muito por causa disso, a gente sempre compra menos quantidade, a gente quer manter tudo novinho pra não perder, sabe, e pro cliente não chegar e já estragar já em casa; a gente tem sempre essa preocupação, de sempre estar novinho.

Entrevistador: Os produtores recebem mais ou menos por estarem trabalhando com vocês? Como forma de incentivo?

Entrevistada: Não. Até que não. Tem um ou dois produtores, que lá em tal lugar eu vou ganhar mais, tipo em Porto Alegre, eles abastecem Porto Alegre, mas lá eles me pagam X a mais, só que esse $\mathrm{X}$ a mais eu não tenho condição de pagar, porque eles vão achar muito mais caro o produto em função disso, sabe.

Entrevistador: E em relação a nível de satisfação? Tem pesquisa? Fazem constante?

Entrevistada: Sim. O Centro Ecológico é um do que as vezes... A gente até... Se tu entrar na página você encontra várias reportagens... Podemos dizer que o nível de satisfação está bom. Comércio né, mas dentro do possível.

Entrevistador: Vocês esmo que cuidam?

Entrevistada: Sim, eu mesma que cuido da página. 
Entrevistador: Se eu mandar questionário por aí, você responde?

Entrevistada: Gostaram da loja?

Entrevistador: Nossa! Sensacional! Localização, identidade visual, o cuidado que vocês têm com a apresentação tanto do produto quanto do ambiente...

Entrevistada: Pra mostrar... Esse aqui é da feirinha, lá do salão...

Entrevistador: E vocês vendem em outro lugar?

Entrevistada: Não. Esses aqui são os nossos produtores. Amanhã tem, é bem legal também. De 8 a meio dia.

Entrevistador: Eu tenho que estar as 10 lá na Federal.

Entrevistada: Seria bem interessante pra vocês conhecerem... Tu ir no nosso Facebook tu vai encontrar. Eu já te adiciono aqui... Tudo o que precisar já vai tá ali na página, do Centro Ecológico, complementando um vídeo, já tem as reportagens dos clientes.

Entrevistador: Vocês tem página também?

Entrevistada: A gente estava pensando, mas ainda não...Foi um vídeo produzido pelo Centro Ecológico.

Entrevistador: Tem muita violência no Sul do país?

Entrevistada: Aqui... Tem. Mas perto de Porto Alegre é que é um lugar muito calmo. Tu pode deixar a casa aberta. Aqui, tu pode deixar o carro aberto pra vir aqui pagar. Pode, é tranquilo. Tem lugar que tu não pode nem ficar dentro do carro parado, coo Porto Alegre, por exemplo, tem lugares que tu tem que abrir de longe o portão. Ano passado teve mais violência, o índice maior. Esse ano a gente não ouviu tanto os boatos, aquelas coisas.... Um abriga de gangue... que daí morreu, mas não morreu inocente... Mas claro, isso não quer dizer que não seja violência.......

Entrevistador: Ele está no Eco Torres. Isso é perfil, não é página?

Entrevistada: Sim, é perfil. Olha, agora tem gente fazendo pedido. Eles pedem, guarda pra mim tanto, etc...

Entrevistador: Mas tem delivery? Tem entrega? 
Entrevistada: A gente tem um cara que está a nossa disposição, tu paga como se fosse... a gente paga o motoboy, a gente se preocupa com isso. A gente liga, arruma, ele leva e a pessoa recebe em casa.

Entrevistador: Face, separa pelo telefone...

Entrevistada: A gente queria porque o perfil limita, a página não. Atende todo mundo.

Entrevistador: Forma de pagamento? Cartão de crédito...

Entrevistada: A gente tá agora evoluindo. Antes não tinha. Mas depois que a gente colocou a maquininha aumentou muito as vendas.

Entrevistador: Parcela?

Entrevistada: Sim. Ainda meu irmão falou pra mim: nossa, vocês parcelam compras pequenas, lá na loja só a partir de tal valor... E aqui a gente parcela, se me pedir, faz em duas vezes? Faço, porque a gente prefere não perder o cliente. Até porque no cartão tu sabe que vai entrar. Crediário, essas coisas assim, a gente não tem.

Entrevistador: Cheque aceita?

Entrevistada: Geralmente a gente aceita, porque os nossos clientes são bem tranquilos, de família, porque o pessoal aqui já chega, peguei tal coisa, depois eu venho aqui... A gente sabe, tu do bem! A gente sabe onde trabalha, a gente sabe quem é, que um grande comércio tu não tem. Só bom dia, boa tarde... Lugar bem movimentado que tu não consegue conversar. Tem cliente de mais idade, que mora sozinho, daí vem, senta e conversa, do filho, a gente também conta as nossas, é bem familiar...

Entrevistador: ONG Onda Verde é o que? Agora que eu mudei de lugar eu vi.

Entrevistada: Desde quando eu era criança, e antigamente eles tinham um local, fora daqui, eles foram despejados, o lugar foi vendido, e eles não tinham pra onde ir, daí a gente já estava com o projeto, e a gente cedeu pra eles, sem custo, sem nada. Porque é ONG, eles não visam. Tudo o que é deles, e ele fazem os projetos nas escolas... E eles trazem as crianças aqui e consomem nossos produtos.

Entrevistador: Eu perguntei do estoque deles, mas o estoque daqui? Vocês têm estoque de produtos secos? 
Entrevistada: Tem sim, daqui pra lá, digamos assim.

Entrevistador: Cozinha pra lanchonete?

Entrevistada: Aí é nossa cozinha, não sei se está arrumada... E a gente tem uma salinha de reunião.

Entrevistador: Bacana! É bem estruturado aqui. Se eu fosse pegar um ponto como esse em Brasília...

Entrevistada: Lá, em terra, não é uma coisa gigante, mas é o Distrito do nosso país...

Entrevistador: Cooperativa de consumidor não tem nenhuma, de produtor a gente tem o mercado orgânico, que é dentro da nossa CEASA, então tudo que chega... É muito misturado, não tem algo que seja atraente pro consumidor. E o mercado orgânico funciona quinta e sábado. Você tem que chegar no máximo até 8 horas da manhã, se não você fica com a "xepa", só o que sobrou. E o chão é aquele batido, uma estrutura que não tem ar condicionado, é um mercadão...

Entrevistada: Estilo rú stico?

Entrevistador: Não é um vintage. É um rústico mal feito mesmo, improvisado. Mas já é um começo. Muita gente vê nisso uma oportunidade de montar uma loja.

Entrevistada: Pois é, podia ter loja lá assim né.

Entrevistador: Eu estou estudando a cooperativa de consumidores, que é a minha linha de pesquisa na UnB, mas eu tô vendo, principalmente em Brasília que algo como isso aqui, é oportunidade de negócio absurda, e forte.

Entrevistada: Tem uma cliente, que é a mulher do nosso contador, que é natural de Brasília, morou até pouco tempo em Brasília... Familiares moram lá... O pessoal de lá sempre pede e ele leva a mala cheia....

Entrevistador: Agora o que a gente passou a ver muito, grande hipermercadistas e atacados que tem uma Native por exemplo, aqui tem Pão de Açúcar? Supermercado? Que é do Extra?...

Entrevistada: Aqui tem outros.. Macro Mix...

Entrevistador: E você chega num desses e eles separaram uma parte só de orgânicos.

Entrevistada: Aqui tem o Nacional, que ele tem o setor de orgânicos. É bem pequeno. 
Entrevistador: Lá, da loja, se não for deste tamanho, tirando a parte do Café, é maior, só de orgânicos dentro de um mercado de bairro, que alguém que vai comprar produto orgânico mas quer fazer compras, comprar vassoura, sabão em pó, qualquer outra coisa, encontra o orgânico lá dentro. Então ele pega, ele acaba sendo um concorrente que tira sua demanda... Tanto que o cliente às vezes vai lá comprar um balde, uma vassoura... Ele acaba tirando uma demanda de uma loja de um mercado orgânico em Brasília. É um concorrente. É uma parte grande.

Entrevistada: Aqui não. Aqui no Nacional sempre teve, mas é muito pequeno. Como se fosse a nossa loja só a metade do deque ali, o setor de orgânicos dele, é bem pequeno. E muitas vezes falta. Tanto das hortaliças, que às vezes nem tem, e os produtos embalados.

Entrevistador: Acho que eu tirei umas fotos. Se eu tirei eu mostro pra vocês. O problema é esse. Porque não tem o que vocês criaram aqui. Aqui vocês começaram e tem esse modelo. Lá, ou o cara vai pra CEASA às 6 horas da manhã ou ele não tem, ou vai pra "xepa". Como ele tem a oportunidade de ir para um mercado, ele acaba indo para o supermercado ao invés de acordar 6h da manhã num sábado ou numa quinta-feira.

Entrevistada: Aqui já é tradicional. A minha mãe, desde que eu era pequeninha, no sábado ela vai na feira, e muita gente. Aqui a gente tem a orgânica e a convencional. Dentro da convencional tem um ou outro que é organico. É muita gente circulando aqui sabe... Já é tradição, já vai acordar pra ir na feira. Algumas coisas não têm mais porque a fiscalização não deixa, mas antes tinha, salame, muitos queijos... A gente sabe as vezes... A gente tinha queijo colonial, que a gente sabia, que tinha sido feitos testes.... só que a gente não pode vender. Não tem embalagem, infelizmente... A gente compra dela, mas pra fazer nosso produto ali dentro, que tem o queijo que a gente quer.

Entrevistador: O que dá mais margem, produto ou lanchonete?

Entrevistada: Produto.

Entrevistador: A lanchonete tá aqui na loja aqui desde sempre?

Entrevistada: Aqui sim, os dois começaram juntos. No caso foi dia 24 de novembro do ano passado a gente abriu neste local aqui. Mas ainda é muito maior o lucro da loja do que o do Café.

Entrevistador: Tem até produto de higiene e limpeza né? Sabonete... 
Entrevistada: Sim, a gente estava trazendo de Brasília, sabão de coco, sabão... A Ana que é fundadora que veio de Brasília.

Entrevistador: O que esse povo de Brasília veio fazer aqui? É bom morar aqui?

Entrevistada: Ela gosta mais daqui do que de lá, segundo ela. O marido dela morava em Minas, foi transferido pro Sul, daí ela acabou vindo junto né. E hoje eles são presidentes do Centro Ecológico daqui, e fundadores da cooperativa. Lá eles têm a renda deles.

Entrevistador: É tipo EMBRAPA? Concursado?

Entrevistada: Não. Ele é particular. Pro centro né... E faz palestras pelo mundo inteiro, sobre isso né...

Entrevistador: Que bom hein...

Entrevistada: Ele fala aqui as vezes... Eu estava na Índia, depois fui pra Grécia... Eu mal vou pra cidade aqui do lado, que dirá pra Suíça! Eles falam com uma naturalidade que pra gente não parece... Claro, que $90 \%$ da viagem é a trabalho, mas eu gostaria de fazer uma viagem de trabalho dessa forma.

Entrevistador: Conhecer o aeroporto de lá já é muito né...

Entrevistada: Inclusive o nosso presidente da cooperativa, dois anos atrás, ganhou do governo, uma viagem pra Europa, justamente devido a nossa cooperativa, ele estava com um projeto CETAC, acho que é só daqui do Sul mesmo, das frutas nativas, daí ele ganhou uma viagem, junto com outras pessoas, claro, e foi pra Europa, ele ficou uns 22 dias, uma coisa assim. Daí foi pra Alemanha, Itália... Conhecer a agricultura de lá. Um trabalho bem legal! Tudo pago. Claro, que o teu extra tu paga, aeroporto, mas pedágio, translado, comida, tudo pago... Digamos que o nosso ramo é muito bom mesmo...

Entrevistador: Tá crescendo. Tá todo mundo de olho, todo mundo querendo saber...

Entrevistada: Se tiver oportunidade de abrir um negócio em Brasília...

Entrevistador: Tem gente assim, que desacredita..

Entrevistada: Mas a gente tem o certificado, assinado... O caso da CEASA... Não sei se vocês viram, no Fantástico... A gente sofreu bastante... 
Entrevistador: E foi daqui né?

Entrevistada: O cara era de Santa Catarina, mas ele vendia na CEASA de São Paulo eu acho. E realmente tinha o certificado de orgânico...

Entrevistador: Ele comprava convencional... Pisou fora da linha né?

Entrevistada: E ele continuou falando que o produto dele era orgânico.

Entrevistador: Aí vem a senhorinha aqui, aponta o dedo e fala que não é.

Entrevistada: Realmente, quem conhece sabe. Assim, como na minha casa, tenho a minha hortinha e sei que consigo produzir um produto bonito, tem que ter o cuidado, mas quantas vezes vem o produto feio, quantas vezes eles perdem. Tomate mesmo, ano passado nosso fornecedor perdeu uma lavoura inteira de tomate, um prejuízo de uns 50 mil reais. Daí, esse ano não, ele conseguiu trazer tomate até pouco tempo, tomate "desse tamanho", porque foi criado em estufa, ele teve que gastar mais pra não poder perder. No começo não, mas no final tava um tomate bem bonito.

Entrevistador: Desperdício da loja tem?

Entrevistada: Tem um pouquinho, mas tem...

Entrevistador: É orgânico né. Não tem como né. A sensibilidade é muito maior.

Entrevistada: Tanto aqui como ali as vezes, acabou secando... As vezes vem o cara de rua e pede...

Entrevistador: Isso que eu ia perguntar, tem algum programa de doação?

Entrevistada: Programa não, mas quando aparece aqui, alguém pedindo, a gente dá. As vezes a gente mesmo leva. Mas $0 \%$ de desperdício é quase impossível... Tem aquela coisa assim, a beterraba e a cenoura, tem muita folha, tem gente que leva, e faz uma omelete e faz coisa, mas a maioria não consegue fazer, e a gente tira um saco de lixo só de folhinhas, etc...

Entrevistador: Muito obrigado!

Entrevistada: Vocês dois fazem a faculdade?

Entrevistador: Só eu, ela só acompanhando. 
Entrevistada: É em que?

Entrevistador: Em Agronegócios. Na verdade, eu sou administrador de empresas, como formação acadêmica, fiz uma especialização em comportamento do consumo e estratégias de marketing, na Fundação Getúlio Vargas, e depois entrei no programa de Mestrado, eu defendo agora, as disciplinas acabaram, essa é a última parte, já fiz a qualificação, aprovaram meu projeto, eu queria que até dezembro eu pudesse apresentar, mas acho que não vai ser possível por conta do trabalho, vou jogar pro meu prazo final que é março de 2017, a gente tem 2 anos como limite. E aí é em Agronegócio. Dentro do Agronegócio, a gente tem duas linhas de pesquisa, então tem um foco em agricultura familiar e orgânicos; e da agricultura familiar eles tiram o orgânico, é porque tem tudo a ver, tem correlação, é orgânico, alto valor agregado... E a outra linha é competitividade, daí é gado, soja, é transgênico, é forte. É forte, porque os caras tem acesso a crédito, tem acesso a grandes propriedades, já produzem há muito tempo

Entrevistada: Quando tem um capital bem grande pra poder investir né... Quando tem um bom capital

Entrevistador: Quando o cara tem a terra, só a propriedade pra colocar como bem de garantia, o governo oferece crédito a um juro muito baixo, e os caras conseguem trabalhar muito bem. Em contrapartida, o agricultor familiar nada, se não for com muita força de vontade, não dá... É difícil convencer os outros com orgânico. E ainda quando vem com o problema, que a gente tem lá é preço né... Nossa! ... 